\title{
Ondersteunende beroepen in het onderwijs : naar een gevalideerd functieraamwerk
}

Citation for published version (APA):

van Loo, J. B., \& de Grip, A. (2007). Ondersteunende beroepen in het onderwijs : naar een gevalideerd functieraamwerk. Researchcentrum voor Onderwijs en Arbeidsmarkt, Faculteit der Economische Wetenschappen. ROA Reports No. 1 https://doi.org/10.26481/umarep.2007001

Document status and date:

Published: 01/01/2007

DOI:

10.26481/umarep.2007001

Document Version:

Publisher's PDF, also known as Version of record

\section{Please check the document version of this publication:}

- A submitted manuscript is the version of the article upon submission and before peer-review. There can be important differences between the submitted version and the official published version of record.

People interested in the research are advised to contact the author for the final version of the publication, or visit the DOI to the publisher's website.

- The final author version and the galley proof are versions of the publication after peer review.

- The final published version features the final layout of the paper including the volume, issue and page numbers.

Link to publication

\footnotetext{
General rights rights.

- You may freely distribute the URL identifying the publication in the public portal. please follow below link for the End User Agreement:

www.umlib.nl/taverne-license

Take down policy

If you believe that this document breaches copyright please contact us at:

repository@maastrichtuniversity.nl

providing details and we will investigate your claim.
}

Copyright and moral rights for the publications made accessible in the public portal are retained by the authors and/or other copyright owners and it is a condition of accessing publications that users recognise and abide by the legal requirements associated with these

- Users may download and print one copy of any publication from the public portal for the purpose of private study or research.

- You may not further distribute the material or use it for any profit-making activity or commercial gain

If the publication is distributed under the terms of Article $25 \mathrm{fa}$ of the Dutch Copyright Act, indicated by the "Taverne" license above, 


\section{Ondersteunende beroepen in het onderwijs}

Naar een gevalideerd functieraamwerk

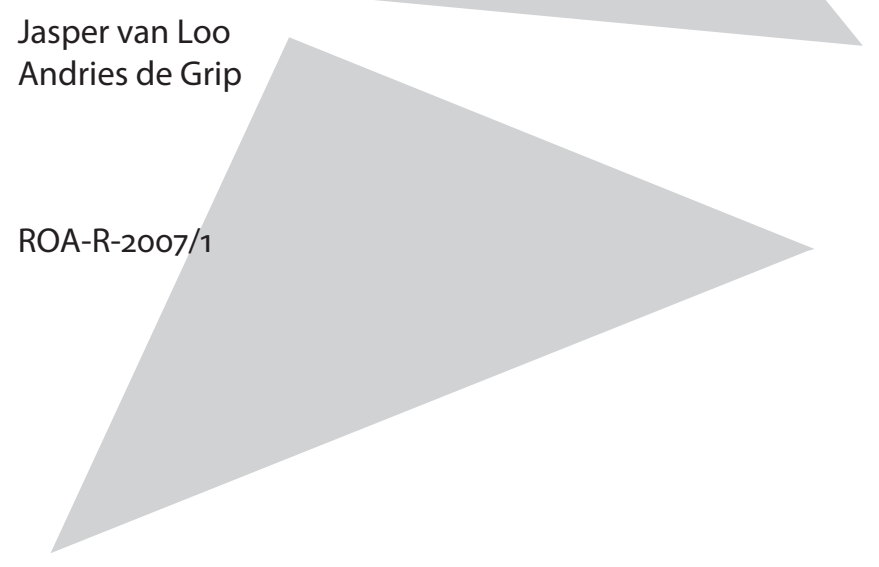




\section{Colofon}

(C) Researchcentrum voor Onderwijs en Arbeidsmarkt (ROA). Niets uit deze uitgave mag op enige manier worden verveelvoudigd zonder voorafgaande schriftelijke toestemming van de directeur van het ROA.

\section{Researchcentrum voor Onderwijs en Arbeidsmarkt}

Faculteit der Economische Wetenschappen en Bedrijfskunde

Universiteit Maastricht

\section{Vormgeving}

ROA secretariaat, Maastricht

\section{Verkoop}

Researchcentrum voor Onderwijs en Arbeidsmarkt

email: secretary@roa.unimaas.nl

website: www.roa.unimaas.nl

ISBN-I3: 978-90-532I-452-7

maart 2007 


\section{Inhoud}

1 Inleiding 1

1.1 Inleiding 1

1.2 Vraagstellingen van het onderzoek 2

1.3 Leeswijzer 4

2 Ordeningskader onderwijsondersteunende functies 5

2.1 Inleiding 5

2.2 Ordeningskader onderwijsondersteunende functies 5

2.3 Pedagogisch/verzorgende onderwijsondersteunende functies 6

2.4 Technisch instrumentele onderwijsondersteunende functies 8

2.5 Pedagogisch/didactische onderwijsondersteunende functies 9

2.6 Overeenkomsten en verschillen tussen de drie typen

$\begin{array}{ll}2.7 \text { Onderzoeksvragen voor de volgende hoofdstukken } & 15\end{array}$

3 Kenmerken van onderwijsondersteunende functies 19

$\begin{array}{ll}3.1 \text { Inleiding } & 19\end{array}$

$\begin{array}{lll}3.2 & \text { Taken } & 20\end{array}$

$\begin{array}{ll}3.3 \text { Activiteiten } & 23\end{array}$

3.4 Benodigde competenties 29

3.5 Complexiteit 34

3.6 Verschillen tussen onderwijssectoren 36

$\begin{array}{ll}3.7 \text { Conclusies } & 40\end{array}$

4 Ondersteuners in het Nederlandse onderwijs 43

4.1 Inleiding 43

4.2 Onderwijsondersteuners in de verschillende onderwijssectoren 44

4.3 De positie van onderwijsondersteuners in het onderwijs 45

4.4 Opleidingsachtergrond van onderwijsondersteuners 49

4.5 Benutting van capaciteiten, kennistekorten en bruikbaarheid van
kennis

$\begin{array}{ll}4.6 \text { Conclusies } & 53\end{array}$ 
5 Samenhang tussen kenmerken van onderwijsondersteunende functies $\quad 55$

$\begin{array}{lll}5.1 \text { Inleiding } & 55\end{array}$

5.2 Correlaties tussen functiekenmerken $\quad 55$

5.3 Clustering van onderwijsondersteunende functies 60

$\begin{array}{ll}5.4 \text { Conclusies } & 65\end{array}$

$\begin{array}{lll}6 & \text { Samenvatting en conclusies } & 67\end{array}$

$\begin{array}{ll}6.1 \text { Inleiding } & 67\end{array}$

$\begin{array}{ll}6.2 \text { Ordeningskader } & 67\end{array}$

$\begin{array}{lll}6.3 & \text { Functiekenmerken van onderwijsondersteuners } & 70\end{array}$

6.4 De positie van onderwijsondersteuners in het Nederlandse onderwijs 71

6.5 Vier verschillende onderwijsondersteunenende functies 73

$\begin{array}{ll}6.6 \text { Conclusies } & 74\end{array}$

Bijlage: Verslag online enquête Onderwijsondersteuners 79 


\section{Inleiding}

\section{$1.1 \quad$ Inleiding}

Als gevolg van verschillende ontwikkelingen is er de afgelopen jaren sprake geweest van een toenemende verticale functiedifferentiatie in het onderwijs. Lumpsumbekostiging, integraal personeelsbeleid, de dreigende tekorten op de arbeidsmarkt en de toenemende behoefte aan menskracht in de klas hebben er toe geleid dat het aantal onderwijsondersteuners, zowel relatief als absoluut gezien, de laatste jaren behoorlijk is toegenomen. Onder onderwijsondersteuners wordt verstaan het personeel dat helpt bij het lesgeven, oftewel het primaire proces in het onderwijs (Vrieze et al, 2003). Niet bedoeld wordt het onderwijsbeheerpersoneel (OBP) zoals bijvoorbeeld conciërges en administrateurs.

Figuur I.I geeft een overzicht van de ontwikkeling van het aantal werkzame onderwijsondersteuners in de jaren 2003-2006 voor het primair onderwijs (PO), het voortgezet onderwijs (VO) en de sector beroeps en volwasseneneducatie (BVE). Het blijkt dat vooral het aantal onderwijsondersteuners dat werkzaam is in het PO de afgelopen jaren aanzienlijk is toegenomen: van circa I.300 in 2003 tot bijna 3.000 in 2006.

Ook in de BVE was er de afgelopen jaren sprake van een groei van het aantal onderwijsondersteuners, maar deze groei is wel duidelijk minder groot: in 2003 waren er circa 3.IOO onderwijsondersteuners in deze sector werkzaam; in 2006 bedroeg dat aantal circa 3.900. In het voortgezet onderwijs is het beeld opmerkelijk genoeg anders. In deze sector was er in de periode 2003-2006 geen sprake van een stijging, maar daalde het aantal onderwijsondersteuners, van bijna 2.700 in 2003 tot circa 2.200 in 2006.

Er is een duidelijk verschil tussen de nieuwe ondersteunende functies en de ondersteunende functies die al langer in het onderwijs bestaan. De traditioneel ondersteunende functies (zoals bijvoorbeeld leerlingenbegeleiding en decanaat) zijn voorbeelden van horizontale functiedifferentiatie. Dat wil zeggen dat deze functies op hetzelfde niveau liggen als de puur onderwijsgevende functies. Bij de nieuwe onderwijsondersteunende functies gaat het om functies op een lager niveau die het primair proces (het geven van onderwijs) ondersteunen. De nieuwe ondersteunende functies zijn daarom een voorbeeld van verticale functiedifferentiatie. 
Figuur 1.1

Aantal werkzame onderwijsondersteuners per onderwijssector, 2003-2006

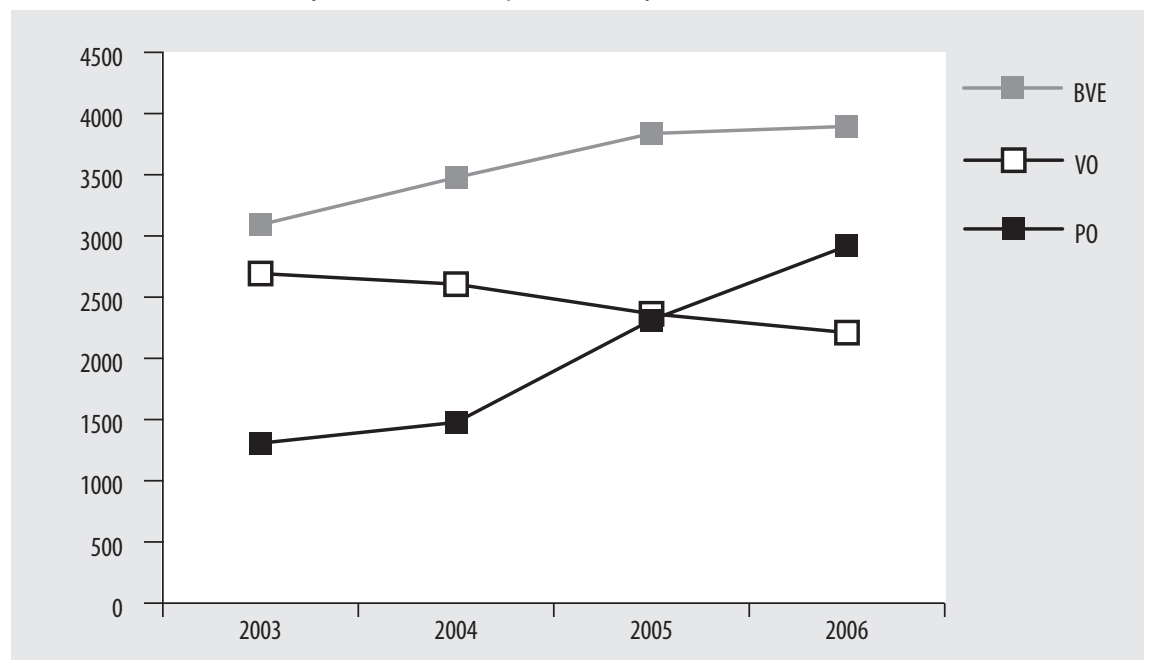

Bron: Aandachtsgroepenmonitor OCenW, www.aandachtsgroepen.nl

\subsection{Vraagstellingen van het onderzoek}

De nieuwe ondersteunende beroepen in het onderwijs hebben in de praktijk een groot aantal verschillende benamingen. Enkele vaak voorkomende functienamen zijn klassenassistent, onderwijsassistent, technisch onderwijsassistent (TOA), leraarondersteuner, instructeur en tutor. Veel van deze ondersteunende functies zijn recentelijk ontstaan. Daarom kan er nog niet gesproken worden van een uitgekristalliseerd beroep. Dat werpt de vraag op wat deze functies dan precies inhouden. Tegen deze achtergrond heeft de Minister van OCenW aan het Landelijk Platform Beroepen in het Onderwijs (LPBO) een aantal kernvragen voorgelegd met betrekking tot ondersteunende beroepen in het onderwijs. Het gaat om de volgende vragen:

- Welke ondersteunende beroepen moeten in het onderwijs worden onderscheiden?

- Welke competentieprofielen horen daarbij?

- Voor welke van de ondersteunde beroepen of werkzaamheden zouden bekwaamheidseisen moeten worden vastgesteld?

Deze drie vragen zijn door het LPBO nader uitgewerkt door het stellen van een aantal gedetailleerde onderzoeksvragen. Het gaat om de volgende vragen:

- Welke onderwijsondersteunende functies komen er voor binnen de verschillende sectoren van het onderwijs? 
- Welke overeenkomsten en verschillen tussen de diverse onderwijsondersteunende functies zijn er te onderscheiden binnen de verschillende onderwijssectoren?

- Hoe verhouden de diverse functieomschrijvingen van onderwijsondersteunende functies binnen het onderwijs zich tot elkaar en de functiegroepen, die zij ondersteunen? Is hierbij sprake van een pedagogische opbouw als inrichtingsprincipe?

- Welke opleidingen zijn er momenteel voor onderwijsondersteunende functies?

- Hoe is het functiebouwwerk georganiseerd in andere sectoren dan het onderwijs, bijvoorbeeld in de zorg?

- Is het mogelijk om onderwijsondersteunende functies in de diverse sectoren van het onderwijs op een logische en samenhangende wijze te positioneren binnen het functiegebouw van het onderwijs en zo ja, op basis van welke ordeningsprincipes?

Een aantal van deze onderzoeksvragen is inmiddels beantwoord in een vooronderzoek dat het LPBO in samenwerking met het Kenniscentrum Beroepsonderwijs Arbeidsmarkt (KBA) heeft uitgevoerd. Dit vooronderzoek is gebaseerd op een aantal gegevens over de inzet van onderwijsondersteuners in de diverse sectoren van het onderwijs, de beschikbare beroepscompetentieprofielen (BCP's) en functiebeschrijvingen voor onderwijsondersteunende functies, andere relevante literatuur en een drietal interviews met vertegenwoordigers uit het onderwijsveld.

Om de door de Minister van OCenW geformuleerde kernvragen volledig te kunnen beantwoorden is er vervolgonderzoek nodig. In het vooronderzoek is weliswaar een goed overzicht gegeven van de inzet van onderwijsondersteuners en de profielen die er voor onderwijsondersteunende functies bestaan, maar de beschikbare secundaire bronnen lieten nog niet toe om diepgaand in te gaan op de inhoud van de onderwijsondersteunende functies in de praktijk en de manieren waarop bepaalde onderwijsondersteunende functies van elkaar verschillen. Hiervoor is nieuw onderzoek nodig, waarbij beroepsbeoefenaren, sleutelpersonen, en/of inhoudsdeskundigen uit het onderwijsveld bevraagd worden.

In dit rapport wordt verslag gedaan van een enquête naar de inhoud van de verschillende onderwijsondersteunende functies. Voor deze enquête zijn zowel schooldirecteuren, leraren als de onderwijsondersteuners zelf benaderd. De enquête is uitgezet in vijf onderwijssectoren: Het primair onderwijs (PO), het speciaal primair onderwijs (SPO), het voortgezet onderwijs (VO), het speciaal voortgezet onderwijs (SVO) en de sector beroeps en volwasseneneducatie (BVE). ${ }^{1}$ Het onderzoek is uitgevoerd door

I. Bij SPO en SVO gaat het om scholen voor speciaal onderwijs $(\mathrm{SBaO})$ en scholen die vallen onder de Wet op de Expertisecentra (WEC). Aangezien zowel het speciaal basisonderwijs voor leerlingen met een handicap als het speciaal voortgezet onderwijs vallen onder de WEC, wordt er in deze rapportage niet gekozen voor de termen $\mathrm{SBaO}$ en WEC. Om voor het speciaal onderwijs een niveau-onderscheid te kunnen maken worden de termen SPO en SVO gebruikt. 
HOOFDSTUK 1

het Researchcentrum voor Onderwijs en Arbeidsmarkt (ROA) van de Universiteit Maastricht uitgevoerd in de maanden december 2006 en januari 2007.

\subsection{Leeswijzer}

In hoofdstuk 2 analyseren we de invloed van de verschillende onderwijsondersteunende functies in het onderwijs aan de hand van het ordeningskader dat het LPBO eerder heeft opgesteld. We sluiten het hoofdstuk af met de onderzoeksvragen die in het vervolg van de rapportage aan de orde zullen komen. In de hoofdstukken 3, 4 en 5 worden de resultaten van een aantal analyses besproken, op basis waarvan de onderzoeksvragen beantwoord kunnen worden. Hoofdstuk 6 sluit deze rapportage af met een samenvatting en een overzicht van de belangrijkste conclusies. 


\section{Ordeningskader onderwijs- ondersteunende functies}

\subsection{Inleiding}

In het onderwijs zijn verschillende typen onderwijsondersteuners werkzaam. Het gaat hoofdzakelijk om functies met de benamingen onderwijs- en klassenassistent, technisch onderwijsassistent (TOA), leraarondersteuner, instructeur, tutor en begeleider. Voor een aantal van deze functies zijn er zogenaamde beroepscompetentieprofielen opgesteld, waarin onder meer de kerntaken van de functie, de kernopgaven en de beroepscompetenties aan de orde komen. Voor andere functies zijn er functie-omschrijvingen beschikbaar. In dit hoofdstuk geven we een overzicht van deze bronnen en bespreken we de belangrijkste verschillen tussen de diverse functies. We werken vanuit een ordeningskader dat het LPBO heeft opgesteld naar aanleiding van het vooronderzoek naar ondersteunende beroepen in het onderwijs. Nadat dit ordeningskader in paragraaf 2.2 besproken is, gaan we in de daarop volgende paragrafen $(2.3,2.4$ en 2.5$)$ in op de kenmerken van de afzonderlijke onderwijsondersteunende beroepen. Paragraaf 2.6 geeft een samenvattend overzicht van de belangrijkste verschillen tussen de onderwijsondersteunende functies. We sluiten af met paragraaf 2.7, waarin we ingaan op de opzet van de volgende hoofdstukken van deze rapportage.

\subsection{Ordeningskader onderwijsondersteunende functies}

Op basis van de verkennende studie naar onderwijsondersteunende beroepen heeft het LPBO geconcludeerd dat de functies ter ondersteuning van het primaire proces in het onderwijs (primair, speciaal, voorgezet en BVE) allen behoren tot één onderwijsondersteunend beroep. Binnen dit beroep zijn er drie verschillende profielen te onderscheiden die, door de aard van de werkzaamheden, ieder een andere oriëntatie hebben. Deze drie profielen zijn:

I. Pedagogisch/verzorgend.

2. Technisch instrumenteel.

3. Pedagogisch/didactisch. 
Deze drie profielen komen ruwweg overeen met de meest voorkomende onderwijsondersteunende functies. Bij de pedagogisch/verzorgende onderwijsondersteunende functies gaat het vooral om onderwijs- en klassenassistenten. De technisch instrumentele onderwijsondersteunende functies hebben betrekking op de technisch onderwijsassistenten (TOA's), terwijl de leraarondersteuners, instructeurs, tutoren en begeleiders pedagogisch/didactische onderwijsondersteunende functies bekleden. Vanwege de verwantschap met de functie leraarondersteuner (zie Onderwijsraad, 2003 en OCenW, 2003) worden ook instructeurs, ondanks het meer vakspecifieke karakter, gerekend tot de pedagogisch/didactische functies. In de volgende paragrafen analyseren we op basis van de beschikbare informatie de inhoud van een aantal onderwijsondersteunende functies. We noemen hier alleen de belangrijkste kenmerken van de besproken functies. Voor meer gedetailleerde informatie verwijzen we naar de achterliggende bronnen.

\subsection{Pedagogisch/verzorgende onderwijsondersteunende functies}

De onderwijs- en klassenassistenten zijn de belangrijkste pedagogisch/verzorgende onderwijsondersteunende functies. Uit de verkennende studie bleek dat de verschillen tussen onderwijs- en klassenassistenten en de verschillen tussen deze functies op verschillende niveaus onduidelijk zijn wanneer er wordt uitgegaan van de beschikbare secundaire informatiebronnen. Voor het beroep onderwijsassistent is er een beroepscompetentieprofiel van de OVDB beschikbaar (OVDB, 2004/2005). Voor de functie klassenassistent bestaat er geen afzonderlijk beroepscompetentieprofiel. Er is alleen een functieomschrijving van het Ministerie van OCenW voor de klassenassistent in het (voortgezet) speciaal onderwijs (Ministerie van OCenW, 2006). Hieronder gaan we in op de belangrijkste kenmerken van deze functies op basis van deze bronnen.

\section{Onderwijsassistent}

Volgens het beroepscompetentieprofiel onderwijsassistent worden in het beroep de volgende kerntaken onderscheiden:

- Het begeleiden van individuele leerlingen en groepen leerlingen tijdens onderwijsleerprocessen.

- Het op aanwijzing van de leraar of het lerarenteam onderdelen van het onderwijsprogramma uitvoeren.

- Het assisteren bij de voorbereidings- en afrondingswerkzaamheden.

- Het uitvoeren van organisatie(deel)taken.

Naast de kerntaken wordt er in het beroepscompetentieprofiel een overzicht gegeven van de kernopgaven voor het beroep onderwijsassistent. De volgende kernopgaven worden genoemd: 
- Afstemming van de eigen verantwoordelijkheid met de verantwoordelijkheid van de leraar/leraren/team.

- Het vinden van de balans tussen leiden en begeleiden.

- Het vinden van de balans tussen veiligheid/structuur en uitdaging/ruimte.

- De eigen grenzen bewaken.

- Het vinden van de balans tussen instrueren/uitleggen/voordoen en zelfontdekkend leren/samen leren.

Het beroepscompetentieprofiel onderwijsassistent vermeldt de volgende beroepscompetenties:

- Interpersoonlijke compententie.

- Pedagogische competentie.

- Didactische competentie.

- Organisatorische competentie.

- Competentie op het gebied van samenwerken met collega's.

- Competentie op het gebied van samenwerken met de omgeving.

- Competentie op het gebied van reflectie en persoonlijke ontwikkeling.

\section{Klassenassistent}

Het ministerie van OCenW heeft een omschrijving opgesteld voor de functie klassenassistent in het (voortgezet) speciaal onderwijs. In deze omschrijving is sprake van twee niveaus: opleidingsniveau 3 en 4 . Voor beide niveaus geldt dat de klassenassistent een aantal taken uitvoert onder verantwoordelijkheid van de leraar. Het profiel vermeldt de volgende taken op niveau 3:

- Het verrichten van werkzaamheden die liggen op het terrein van de lichamelijke verzorging en het ondersteunen van de leerling tijdens het volgen van de lessen waar nodig, waarbij in de uitoefening van de taken de zorg en aandacht voor de individuele leerling centraal staan.

- Het verrichten van overige werkzaamheden die verband houden met de functie.

De taken voor de klassenassistent op niveau 4 zijn de volgende:

- Het ondersteunen van de leraar bij het verrichten van eenvoudige routinematige onderwijsinhoudelijke taken.

- Het begeleiden van leerlingen bij het verwerven van vaardigheden.

- Het verrichten van verzorgende werkzaamheden.

- Het leveren van een praktische/organisatorische bijdrage aan het klassenmanagement.

- Het verrichten van overige werkzaamheden die verband houden met de functie. 
De functieomschrijving voor klassenassistenten van OCenW bevat geen informatie over kernopgaven en beroepscompetenties.

\subsection{Technisch instrumentele onderwijsondersteunende functies}

\section{Technisch onderwijsassistent (TOA)}

Bij technisch instrumentele onderwijsondersteunende functies gaat het om technisch onderwijsassistenten (TOA's). Het door de VAPRO opgestelde beroepscompetentieprofiel $\left(\mathrm{VAPRO}^{\mathrm{I}}\right.$, 2004) geeft een overzicht van de kerntaken, de kernopgaven en de beroepscompetenties voor dit beroep.

In het beroepscompetentieprofiel TOA worden de volgende kerntaken genoemd:

- Het faciliteren van practica en vakoverstijgende werkzaamheden.

- Het begeleiden van leerlingen tijdens practica en vakoverstijgende werkzaamheden.

Voor de TOA zijn de volgende kernopgaven van toepassing:

- Tijd versus kwaliteit.

- Omgaan met leerlingen en samenwerken met de docent.

- Planning versus flexibiliteit.

- Inzicht tonen.

De volgende beroepscompetenties worden genoemd:

- Voorraad beheren.

- Administratieve werkzaamheden uitvoeren.

- Wensen van de docent in kaart brengen.

- Plannen van werkzaamheden.

- Haalbaarheid van practicum bepalen.

- Proeven ontwikkelen.

- Bijdragen aan proefontwikkeling.

- Beoordelen of werkstuk voldoet.

- Instructie geven.

- Adequaat uitvoeren van practicum/werkstuk beoordelen.

- Leerlingen beoordelen.

- Communiceren tijdens werkzaamheden.

- Overleg voeren.

- Samenwerken.

I. Vakorganisatie voor de procesindustrie. 
- Ontwikkelingen volgen.

- Beroepscompetenties ontwikkelen.

- Veilig en milieubewust werken.

- Schoonmaken en opruimen werkplek.

\subsection{Pedagogisch/didactische onderwijsondersteunende functies}

Leraarondersteuners, instructeurs, tutoren en begeleiders worden gezien als pedagogisch/didactische onderwijsondersteunende functies. Voor de eerste drie functies zijn geen beroepscompetentieprofielen beschikbaar maar wel enkele functieomschrijvingen. Over de inhoud van de functie begeleider is er geen informatie voorhanden.

\section{Leraarondersteuner}

Het ministerie van OCenW (OCenW, 2006) geeft een overzicht van de werkzaamheden die leraarondersteuners in het primair onderwijs uitvoeren. Het gaat om de volgende werkzaamheden:

- Onder de verantwoordelijkheid van een leraar les(ondersteunende) en leerlingenbegeleidende taken uitvoeren.

- De onderwijsvoorbereiding ondersteunen.

- Bijdragen leveren aan de schoolorganisatie.

- Zich actief opstellen in het ontwikkelen van competenties.

Naast de werkzaamheden zijn er ook een aantal kenmerken van het beroep die de speelruimte aanduiden. Het gaat om het volgende:

- Functioneel verantwoording afleggen aan de leraar over de wijze van lesgeven en de begeleiding van leerlingen conform de instructie van de leraar, aan de hand van handelingsplannen en zoals voorzien in het zorgplan.

- Werkzaamheden verrichten conform de aanwijzingen van de leraar alsmede op basis van het lesplan en de behandel- en zorgplannen.

- Beslissingen nemen bij het lesgeven en het begeleiden van leerlingen.

De functiebeschrijving voor leraarondersteuner vermeldt geen beroepscompetenties, maar geeft wel een overzicht van de kennis en vaardigheden die vereist zijn voor de functie. Het gaat om de volgende kennis en vaardigheden:

- Didactische en pedagogische kennis en vaardigheden.

- Kennis van de leerstof.

- Inzicht in de organisatie en werkwijze van de eigen school.

- Invoelingsvermogen en sociale vaardigheden.

- Vaardigheid in het overdragen van kennis en vaardigheden. 
Ten slotte wordt er in de functieomschrijving een overzicht gegeven van de contacten die een leraarondersteuner onderhoudt:

- Contacten met leerlingen om de leerstof te bespreken en uit te leggen.

- Contacten met leraren, om de vorm en werkwijze van de lesondersteuning en leerlingen te bespreken en de leraren te informeren over de leerresultaten en leer- en gedragsproblemen.

- Contacten met ouders, over de ontwikkeling van de leerling, tijdens ouderavonden, ter assistentie van de leraar.

- Contacten met collega-leraarondersteuners, over de eigen werkzaamheden in de vorm van collegiale besprekingen/consultaties.

\section{Instructeur}

Het Koning Willem I College in 's Hertogenbosch heeft een functieprofiel voor de functie instructeur (KWCI, 2006) opgesteld. Het profiel spreekt over een drietal resultaatgebieden:

I. Begeleiden van individuele en groepen leerlingen bij het praktijkgedeelte.

2. Bijdragen aan de ontwikkeling en vernieuwing van het praktijkonderwijs.

3. Rapportage naar de leraren van een organisatie-eenheid.

Aan deze drie resultaatgebieden zijn een aantal kernactiviteiten verbonden:

Kernactiviteiten voor resultaatgebied I:

- Het op basis van een lesprogramma van een leraar samenstellen, inrichten en geven van praktijkinstructie aan individuele en/of groepen leerlingen.

- Het beoordelen van de einduitkomsten/onderzoeksresultaten van door de leerlingen uitgevoerde opdrachten.

Kernactiviteiten voor resultaatgebied 2:

- Het aangeven van verbeteringsmogelijkheden voor de organisatie van de praktijklessen.

- Het adviseren over de aanschaf van apparatuur, materialen en gereedschappen.

- Het schrijven/samenstellen van (delen van) instructiemateriaal, (veiligheids-) voorschriften.

Kernactiviteiten voor resultaatgebied 3:

- Het mede evalueren van de opzet van proeven/praktijkopdrachten/afstudeeropdrachten.

- Het mede samenstellen en beoordelen van (delen van) proefwerken/examens.

- Het mede ontwikkelen van het praktijkgedeelte van cursussen t.b.v. bedrijven, instellingen en/of individuele leerlingen.

- Het uitvoeren van opdrachten bestaande uit de uitvoering van praktijksimulaties in een projectmatige organisatorische context. 
- Het meewerken aan grotere en vernieuwende, niet standaard opdrachten onder begeleiding van een leraar.

- Het mede bijdragen aan schoolelementen, voorlichtingsactiviteiten, e.d.

Het functieprofiel instructeur geeft ook een overzicht van de benodigde kennis en vaardigheden voor de functie:

- Kennis van en ervaring met de bedrijfspraktijk.

- Algemene theoretische kennis van pedagogische en didactische methoden en technieken.

- Kennis van (de toepassing van) nieuwe technologieën.

- Inzicht in het aanleren van praktische vaardigheden.

Naast kennis en vaardigheden wordt er ook een overzicht gegeven van de voor de functie benodigde competenties:

- Pedagogisch competent.

- Vak- en didactisch competent.

- Organisatorisch competent.

- Interpersoonlijk competent.

- Competent i.s.m. collega's.

- Competent i.s.m. de omgeving.

- Competent in reflectie en ontwikkeling.

De instructeur heeft de volgende beslissingsbevoegdheden:

- De inhoudelijke inrichting van de praktijkinstructie en begeleiding op basis van het lesprogramma.

- Werkafspraken en veiligheidsvoorschriften die van belang zijn voor de uitvoering van de instructietaak.

- Adviezen over de verbetering van de aanpak en uitvoering van de praktijklessen.

Het functieprofiel voor de instructeur besteedt ook aandacht aan de verschillende contacten die de instructeur op het werk heeft:

- Contacten met leerlingen en ouders over wensen, voortgang, resultaten e.d.

- Contacten met leidinggevenden, leraren en collega's binnen en buiten de eigen opleiding over programma's, vernieuwing, onderlinge afstemming e.d. 
Ook voor de functie tutor heeft het Koning Willem I College in 's Hertogenbosch een functieprofiel (KWCI, 2006) opgesteld. Het profiel voor deze functie heeft dezelfde indeling als het functieprofiel voor instructeurs en gaat achtereenvolgens in op resultaatgebieden, kernactiviteiten per resultaatgebied, kennis en vaardigheden, competenties, beslissingsbevoegdheden en contacten.

\section{Resultaatgebieden}

1. Begeleiding van individuele en kleine groepen leerlingen.

2. Verschaffen van informatie aan zowel groepen als individuele leerlingen, en aan leraren van de organisatie-eenheid.

3. Rapportage naar de leraren van een organisatie-eenheid en samenwerkende partijen.

Kernactiviteiten voor resultaatgebied I:

- Het volgens het onderwijsprogramma toepassen van begeleidingstechnieken waarbij het procesmatige karakter van de begeleiding optimaal wordt afgestemd op de behoefte van de leerling.

- Het begeleiden en het geven van adviezen aan leerlingen bij studiemoeilijkheden.

- Het opzetten van een leerlingvolgsysteem ter bewaking van het begeleidingsproces, voortgang van studieplannen voor leerlingen en samenwerkende partijen.

- Een bijdrage leveren aan ontwikkeling en het mede vaststellen van leer- en oefenstof, leermiddelen en materialen.

Kernactiviteiten voor resultaatgebied 2:

- Het binnen het onderwijsprogramma maken van een studieplan/werkplan in termen van haalbare en meetbare activiteiten met betrekking tot de inzet van eigen vaardigheden, beschikbare middelen en ondersteuningsbehoefte van individuele leerlingen.

- Het inventariseren van de ondersteuningsbehoefte van leerlingen en deze in verband brengen met de eigen mogelijkheden en die van de organisatieeenheid.

Kernactiviteiten voor resultaatgebied 3:

- Het signaleren van probleemsituaties en voorstellen doen om deze op te heffen.

- Het afstemmen van (hulp)onderwijsvragen op de gewenste begeleiding en het doen van verbeteringsvoorstellen om de afstemming van de begeleiding optimaal aan te laten sluiten op het lesprogramma. 
- Praktische kennis van zowel individuele als van groepsbegeleidingsmethoden voor kleine en middelgrote groepen.

- Algemene theoretische kennis van didactische methoden en technieken.

- Kennis van nieuwe technologieën.

\section{Vaardigheden:}

- Vaardig in het inventariseren van de ondersteuningsbehoeften van leerlingen en het inspelen hierop bij de (individuele) begeleiding.

- Vaardig in het motiveren van leerlingen.

- Vaardig in het maken van studieplannen voor leerlingen.

- Vaardig in het toepassen van diverse didactische methoden en technieken.

\section{Competenties:}

- Pedagodisch competent.

- Vak- en didactisch competent.

- Organisatorisch competent.

- Interpersoonlijk competent.

- Competent i.s.m. collega's.

- Competent i.s.m. de omgeving.

- Competent in reflectie en ontwikkeling.

\section{Beslissingsbevoegdheden:}

- Beslissen bij/over het begeleiden van individuele leerlingen en groepen leerlingen.

- Beslissen bij/over het opstellen van studie/werkplannen.

- Beslissen bij/over het ontwikkelen en mede vaststellen van leer- en oefenstof, leermiddelen en materialen.

- Beslissen bij/over de afstemming van onderwijsvragen en behoeften van leerlingen op de gewenste begeleiding.

\section{Contacten:}

- Contacten met individuele en groepen leerlingen over de voortgang, de resultaten en de ondersteuningbehoefte om hen op een effectieve manier te kunnen begeleiden.

- Contacten met leraren over de opzet en uitvoering van de begeleiding om die af te stemmen op de lesprogramma's, onderwijsvraag en om verbeteringsvoorstellen te doen voor het optimaal gebruik van de begeleiding. 


\subsection{Overeenkomsten en verschillen tussen de drie typen onderwijsondersteunende functies}

Op basis van de beschikbare informatiebronnen met betrekking tot onderwijsondersteunende functies kan de indeling van de onderwijsondersteunende functies in drie profielen als volgt worden samengevat:

\section{Pedagogisch/verzorgende onderwijsondersteunende functies}

Het gaat hier om de functies onderwijsassistent en klassenassistent. In deze functies staat het begeleiden van individuele leerlingen en groepen leerlingen centraal. Bij onderwijsassistenten ligt de nadruk op het onderwijsproces en het uitvoeren van onderdelen van het onderwijsprogramma, inclusief de voorbereidings- en afrondingswerkzaamheden. Voor de klassenassistent opgeleid op niveau 3 gaat het met name om het ondersteunen bij de lichamelijke verzorging en het ondersteunen van de leerling tijdens het volgen van de lessen. Klassenassistenten opgeleid op niveau 4 voeren daarnaast eenvoudige routinematige onderwijsinhoudelijke taken uit, begeleiden leerlingen bij het verwerven van vaardigheden en leveren een praktische bijdrage aan het klassenmanagement. Een vergelijking tussen kernopgaven en beroepscompetenties is niet mogelijk, aangezien deze informatie voor klassenassistenten niet beschikbaar is.

\section{Technisch instrumentele onderwijsondersteunende functies}

Het gaat hier om technisch onderwijsassistenten (TOA's). Het werk van een TOA heeft twee kerntaken: het faciliteren van practica en vakoverstijgende vaardigheden en het begeleiden van leerlingen tijdens practica en vakoverstijgende werkzaamheden. De TOA heeft te maken met vier kernopgaven: tijd versus kwaliteit, omgaan met leerlingen en samenwerken met de docent, planning versus flexibiliteit en inzicht tonen. Het beroepscompetentieprofiel van de TOA wijkt duidelijk af van het profiel van de onderwijsassistent. Voor onderwijsassistenten zijn de zowel de kerntaken als de kernopgaven meer toegespitst op de pedagogische aspecten van het leerproces. Ook de benodigde beroepscompetenties zijn anders. Voor een TOA zijn de benodigde competenties voor het merendeel technisch van aard. Onderwijsondersteuners met pedagogisch/verzorgende functies moeten vooral beschikken over pedagogische/ didactische en communicatieve competenties.

\section{Pedagogisch/didactische onderwijsondersteunende functies}

Het gaat om leraarondersteuners, instructeurs, tutoren en begeleiders. Voor de eerste drie functies zijn er functieomschrijvingen beschikbaar. Voor instructeurs en tutoren zijn deze echter relatief contextspecifiek (geldend voor een specifieke school). Voor begeleiders is er helaas geen functieomschrijving beschikbaar. Leraarondersteuners in het primair onderwijs voeren lesondersteunende en leerlingenbegeleidende taken uit onder verantwoordelijkheid van een leraar, ondersteunen de onderwijsvoorbereiding, 
dragen bij aan de schoolorganisatie en stellen zich actief op in het ontwikkelen van competenties. Verder moeten ze functioneel verantwoordelijkheid afleggen aan de leraar en handelen naar hun aanwijzingen. Tijdens de les wordt er voor leraarondersteuners echter ook een zelfstandige beslisvaardigheid verwacht. De voor de functie benodigde kennis en vaardigheden zijn didactische en pedagogische kennis, vakinhoudelijke kennis, organisatorische en sociale vaardigheden en de vaardigheid om kennis en vaardigheden over te dragen.

Bij instructeurs ligt de nadruk op het geven van praktijkonderwijs en het begeleiden van leerlingen daarbij. Opmerkelijk is dat ook het bijdragen aan de ontwikkeling en vernieuwing van het praktijkonderwijs genoemd wordt als resultaatgebied. Deze innovatiegerichtheid weerspiegelt zich ook in de benodigde kennis en vaardigheden: Zowel de toepassing van nieuwe technologieën als het aanleren van nieuwe vaardigheden zijn een vereiste voor de functie.

Voor tutoren ligt de nadruk in de werkzaamheden op het begeleiden van individuele en kleine groepen leerlingen en het doorgeven van informatie aan leerlingen en leraren. Hiervoor is praktische kennis van zowel individuele als van groepsbegeleidingsmethoden vereist. Ook een gedegen kennis van nieuwe technologieën is een vereiste. Tutoren moeten bovendien vaardig zijn in het inventariseren van behoeften van leerlingen, het motiveren en het maken van studieplannen.

\subsection{Onderzoeksvragen voor de volgende hoofdstukken}

De analyse van de verschillende bronnen die betrekking hebben op de inhoud van onderwijsondersteunende functies maakt duidelijk dat het erg moeilijk is om vanuit theoretisch oogpunt vergelijkingen te maken tussen de verschillende ondersteunende beroepen in het onderwijs. Er is een aantal problemen dat de vergelijking problematisch maakt:

- Allereerst zijn er grote verschillen in de opzet van de verschillende informatiebronnen. Sommige bronnen spreken van kerntaken en beroepscompetenties; andere hebben het over resultaatgebieden of werkzaamheden en gaan in op de voor de functie benodigde kennis en vaardigheden.

- Daarnaast is er in een aantal informatiebronnen sprake van een contextspecifieke benadering. Terwijl de beroepscompetentieprofielen voor technisch onderwijsassistenten (TOA's) en met name onderwijsassistenten relatief breed zijn opgesteld, hebben de bronnen voor andere onderwijsondersteunende functies betrekking op één specifieke onderwijssector (bijvoorbeeld het primair onderwijs) of zelfs op één specifieke school.

- Ten slotte zijn er grote verschillen in de mate van detaillering. Voor de onderwijsondersteunende beroepen waarvoor een beroepscompetentieprofiel is vastgesteld is er uitgebreide informatie beschikbaar over de facetten die binnen de 
kerntaken van de functie belangrijk zijn. Het gaat dan bijvoorbeeld om het proces, de rol en verantwoordelijkheden, de mate van complexiteit, de betrokkenen, de hulpmiddelen, de kwaliteit van het proces en het resultaat en de keuzes en dilemma's. In andere bronnen wordt er alleen melding gemaakt van activiteiten die binnen de context van een tak bij de functie horen.

Dit alles betekent dat de verschillen en overeenkomsten die we in dit hoofdstuk vonden met de nodige voorzichtigheid moeten worden geïnterpreteerd. Om een beter inzicht te krijgen in de manieren waarop de verschillende onderwijsondersteunende functies in de praktijk van elkaar verschillen en wat de overeenkomsten zijn tussen onderwijsondersteuners in verschillende contexten is een andere onderzoeksmethode nodig.

In de drie volgende hoofdstukken doen we verslag van een empirisch onderzoek dat gericht is op het op een structurele manier in kaart brengen van het onderwijsondersteunend beroep en de diverse varianten die daarbinnen bestaan. Daarbij proberen we een antwoord te geven op de volgende onderzoeksvragen:

I. In hoeverre vinden beroepsbeoefenaren binnen de verschillende onderwijssectoren de zienswijze op het onderwijsondersteunend beroep en de indeling in drie profielen valide?

2. Met welke argumenten legitimeren zij hun standpunt ten aanzien van de validiteit van deze zienswijze en indeling?

3. In welke mate ontlenen zij hun argumenten aan de beroepspraktijk, de arbeidsorganisatie en/of de onderwijsberoepskolom?

4. In hoeverre vinden beroepsbeoefenaren binnen de verschillende onderwijssectoren deze indeling volledig?

5. Indien deze indeling als niet volledig wordt beschouwd, wat moet hieraan worden toegevoegd?

6. Welke ondersteunende functies binnen scholen passen volgens de beroepsbeoefenaren binnen de profielen?

7. Zijn beroepsbeoefenaren binnen de verschillende onderwijssectoren van mening dat de drie profielen voldoende onderscheidend zijn van elkaar?

8. Welke argumenten brengen zij naar voren om hun mening te onderbouwen?

9. Indien profielen voldoende onderscheidend worden geacht, wat is dan het specifiek onderscheidende van ieder afzonderlijk profiel?

IO. Is er een rechtvaardiging voor een niveau-onderscheid binnen de verschillende profielen?

II. Verschillen de antwoorden van beroepsbeoefenaren op de vragen I t/m IO voor de diverse onderwijssectoren?

Om deze vragen te kunnen beantwoorden analyseren we in de komende hoofdstukken de verschillende onderwijsondersteunende functies in het Nederlandse onderwijs. In 
hoofdstuk 3 en 4 analyseren we de inhoud van het werk van onderwijsondersteuners en de context waarin ze werken. Daarbij wordt er uitgegaan van de driedeling in pedagogisch/verzorgende, technisch instrumentele en pedagogisch/didactische functies.

In hoofdstuk 3 wordt er uitgebreid stilgestaan bij de verschillen tussen de drie onderscheiden onderwijsondersteunende functies op basis van een vergelijking van een groot aantal functiekenmerken. Daarbij zal er worden ingegaan op de taken, bezigheden, verantwoordelijkheden, zelfstandigheid, benodigde competenties en complexiteit van het werk. In dit hoofdstuk zullen we telkens kijken naar de verschillen tussen en overeenkomsten van de drie soorten onderwijsondersteunende functies. Daarnaast zal er kort worden ingegaan op de belangrijkste verschillen tussen de onderwijssectoren.

In hoofdstuk 4 wordt ingegaan op de context waarbinnen onderwijsondersteuners werkzaam zijn, met welke opleidingsachtergrond ze hun functies uitvoeren in welk soort scholen ze werkzaam zijn. Ook wordt er, in algemene zin, ingegaan op de mate waarin hun werk aansluit bij de opleiding die ze gevolgd hebben, of hun capaciteiten in de huidige functie worden benut, of er kennistekorten bestaan en in hoeverre de kennis en vaardigheden die onderwijsondersteuners hebben bruikbaar zijn buiten de functie die ze nu hebben.

In hoofdstuk 5 kijken we op basis van correlatie-analyses en de principale componenten methode naar de mate van samenhang tussen de verschillende functiekenmerken. Daarbij zal onderzocht worden of de functiekenmerken van onderwijsondersteuners de indeling in drie profielen ondersteunen of juist wijzen op een andere manier van indelen. Hoofdstuk 6 presenteert de belangrijkste conclusies van het onderzoek. 



\section{Kenmerken van onderwijs- ondersteunende functies}

\subsection{Inleiding}

In dit hoofdstuk kijken we naar de kenmerken van onderwijsondersteunende functies. De nadruk daarbij ligt op het analyseren van de verschillen tussen pedagogisch/ verzorgende, technisch instrumentele en pedagogisch/didactische functies. Bij het analyseren van de verschillende ondersteunende functies in het onderwijs bekijken we een groot aantal specifieke kenmerken van het werk. Daarmee sluiten we aan bij de informatie die er voor deze functies bestaat. Achtereenvolgens gaan we in op:

- De taken die onderwijsondersteuners vervullen.

- De activiteiten in de functie.

- De voor de functie benodigde competenties.

- De verantwoordelijkheden in de functie.

- De complexiteit van de functie.

Ieder kenmerk van de onderwijsondersteunde functie wordt gemeten aan de hand van een aantal verschillende items. Ook deze items zijn gebaseerd op de beschikbare informatiebronnen over de verschillende onderwijsondersteunende functies die in hoofdstuk 2 aan de orde kwamen. In dit hoofdstuk ligt de nadruk op het vergelijken van de drie door het LPBO onderscheiden profielen voor onderwijsondersteunende functies.

De indeling van dit hoofdstuk is als volgt. In paragraaf 3.2 kijken we naar de taken van de onderwijsondersteuners en de mate waarin onderwijsondersteuners deze taken zelfstandig uitvoeren. Vervolgens gaan we in paragraaf 3.3 in op de activiteiten van de onderwijsondersteuners. Ook gaan we in op de vraag wie de verantwoordelijkheid draagt voor deze activiteiten. In paragraaf 3.4 gaan we in op de competenties van onderwijsondersteuners. Daarbij staat de vraag centraal welke competentie-aspecten vereist zijn in het werk. Daarnaast kijken we naar de wijze waarop onderwijsondersteuners de verschillende competentie-aspecten hebben geleerd. In paragraaf 3.5 kijken we naar de complexiteit van onderwijsondersteunende functies. Daarbij analyseren we een aantal factoren die het werk potentieel complex maken en bekijken we of er tussen de verschillende soorten onderwijsonderwijsondersteunende functies 
op dit punt verschillen bestaan. In paragraaf 3.6 gaan we kort in op de verschillen tussen de onderwijssectoren die er op het vlak van de taken, de activiteiten en de vereiste competenties bestaan. Paragraaf 3.7 sluit het hoofdstuk af met de belangrijkste conclusies.

\subsection{Taken}

Welke taken hebben onderwijsondersteuners in hun werk? Op basis van een analyse van de profielen die voor een aantal onderwijsondersteunende functies beschikbaar zijn (zie ook hoofdstuk 2) kijken we naar de mate waarin de volgende I4 taken voorkomen in het takenpakket van onderwijsondersteuners:

- Voorbereidings- en afrondingswerkzaamheden van lessen uitvoeren.

- Onderdelen van het onderwijsprogramma uitvoeren.

- Bijdragen aan een goed pedagogisch klimaat.

- Extra-curriculaire activiteiten organiseren.

- Individuele leerlingen tijdens het onderwijsproces begeleiden.

- Kleine groepen leerlingen tijdens het onderwijsproces begeleiden.

- Individuele leerlingen buiten het onderwijsproces begeleiden.

- Kleine groepen leerlingen buiten het onderwijsproces begeleiden.

- Leerlingen beoordelen en toetsen.

- Practica en experimenten faciliteren.

- Leerlingen tijdens practica en experimenten begeleiden.

- Leerlingen bij het inoefenen van beroepsvaardigheden begeleiden.

- Zorg (fysiek of sociaal-emotioneel) bieden aan leerlingen.

- Administratieve werkzaamheden uitvoeren.

\section{Frequentie van voorkomen van taken in het takenpakket}

In het onderzoek is gevraagd om aan te geven hoe vaak de genoemde taken voorkomen in het takenpakket van onderwijsondersteuners. In figuur 3.I kijken we naar de frequentie waarmee de verschillende taken voorkomen in het takenpakket van onderwijsondersteuners met pedagogisch/verzorgende, technisch instrumentele en pedagogisch/didactische functies. In de figuur wordt de gemiddelde score voor de drie onderscheiden soorten onderwijsondersteunende functies weergegeven.

Figuur 3.I laat duidelijk zien dat er tussen de drie onderwijsondersteunende functies verschillen zijn in het takenpakket. Er zijn echter slechts kleine verschillen in de frequentie waarmee onderwijsondersteuners voorbereidings - en afrondingswerkzaamheden van lessen uitvoeren. Een tweede belangrijke conclusie is dat er sprake lijkt te zijn van een tweedeling tussen pedagogisch/verzorgende en pedagogische/didactische functies enerzijds en technisch instrumentele functies anderzijds. Veel taken komen namelijk vaker voor in de pedagogisch/verzorgende functies en pedagogisch/didacti- 
sche functies dan in het takenpakket van technisch instrumentele onderwijsondersteunende functies. Daarbij gaat het om de volgende taken:

- Onderdelen van het onderwijsprogramma uitvoeren.

- Bijdragen aan een goed pedagogisch klimaat.

- Extra-curriculaire activiteiten organiseren.

- Individuele leerlingen tijdens het onderwijsproces begeleiden.

- Kleine groepen leerlingen tijdens het onderwijsproces begeleiden.

- Individuele leerlingen buiten het onderwijsproces begeleiden.

- Kleine groepen leerlingen buiten het onderwijsproces begeleiden.

- Leerlingen beoordelen en toetsen.

\section{Figuur 3.1}

Mate waarin onderwijsondersteuners verschillende taken uitvoeren

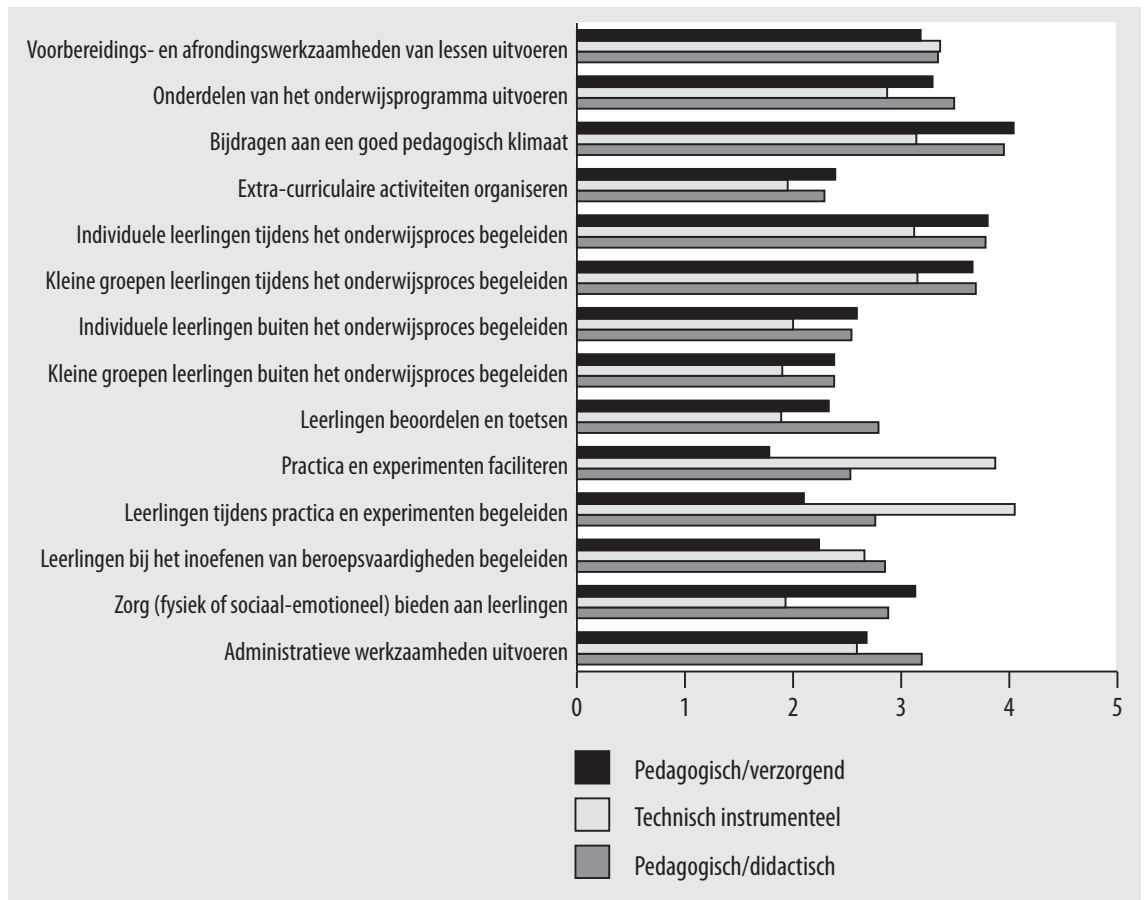

Noot: het gaat hier om de gemiddelde scores van de frequentie waarmee de taken voorkomen in het takenpakket. De frequenties zijn gemeten op een vijfpuntsschaal

Daarentegen komen de taken practica en experimenten faciliteren en leerlingen tijdens practica en experimenten begeleiden vaker voor in het werk van ondersteuners met een technisch instrumentele functie dan in het werk van ondersteuners met een pedagogisch/verzorgende of pedagogisch/didactische functie. 
Het begeleiden van leerlingen bij het inoefenen van beroepsvaardigheden is een taak die het meeste voorkomt bij de ondersteuners met een pedagogisch/didactische functie. Deze taak is wat minder van belang voor ondersteuners met technisch instrumentele of pedagogisch/verzorgende functies. Zorg bieden (fysiek of sociaal-emotioneel) aan leerlingen is een taak die juist het meest van belang is in de pedagogisch/verzorgende onderwijsondersteunende functies. Deze taak behoort veel minder vaak tot het takenpakket van technisch onderwijsondersteuners. Administratieve werkzaamheden en leerlingen beoordelen en toetsen komen het meeste voor in het takenpakket van ondersteuners met pedagogisch/didactische functies.

\section{Zelfstandigheid bij het uitvoeren van taken}

Ook de mate waarin de verschillende taken zelfstandig worden uitgevoerd is een belangrijk functiekenmerk. In figuur 3.2 wordt een overzicht gegeven van het percentage onderwijsondersteuners dat de taken die ze hebben zelfstandig uitvoert. Ondersteuners die bepaalde taken niet in hun takenpakket hebben zitten zijn daarbij buiten beschouwing gebleven.

\section{Figuur 3.2}

Percentage werknemers dat taken zelfstandig uitvoert, per soort onderwijsondersteuner

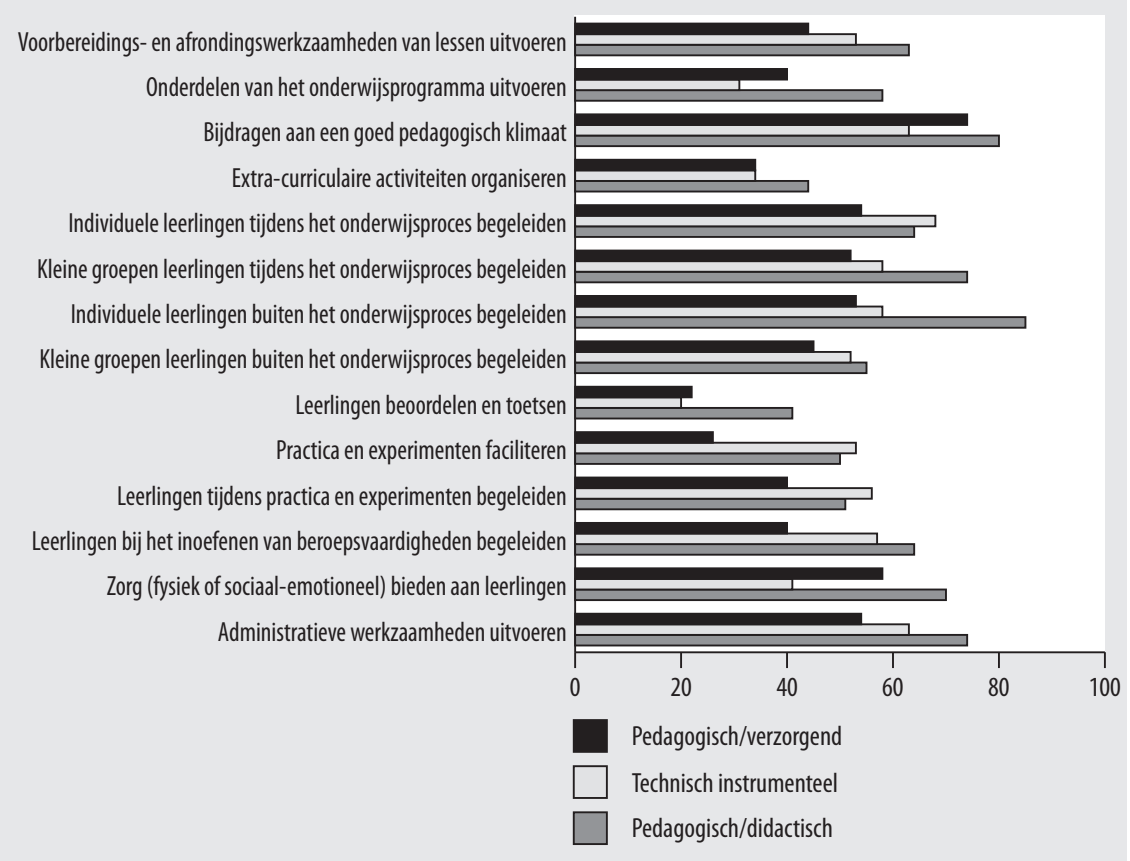

Noot: $\mathrm{Er}$ is geselecteerd op onderwijsondersteuners waarvoor de betreffende taak deel uit maakt van het takenpakket 
De mate van zelfstandigheid is het grootst in de pedagogisch/didactische functies. Voor II van de I4 taken is het percentage ondersteuners dat de taak zelfstandig uitvoert het grootst in deze onderwijsondersteunende functies. De taken bijdragen aan een goed pedagogisch klimaat en individuele leerlingen buiten het onderwijsproces begeleiden worden door circa $80 \%$ van de ondersteuners met pedagogisch/didactische functies zelfstandig uitgevoerd. Voor het begeleiden van individuele leerlingen tijdens het onderwijsproces, het faciliteren van practica en experimenten en het begeleiden van leerlingen tijdens practica en experimenten is het beeld anders. Voor deze drie taken is de mate van zelfstandigheid het grootst voor ondersteuners met een technisch instrumentele functie.

Het is verder opvallend dat de mate van zelfstandigheid waarmee ondersteuners met pedagogisch/verzorgende functies de taken in hun functie uitvoeren voor een tweetal taken relatief beperkt is. Zo voert bijvoorbeeld slechts $20-30 \%$ van de ondersteuners met deze functies de taken leerlingen beoordelen en toetsen en practica en experimenten faciliteren zelfstandig uit.

\subsection{Activiteiten}

De taken die onderwijsondersteuners moeten verrichten zijn bepalend voor het soort activiteiten dat ze in hun functie uitvoeren. Ook bij het vaststellen van de activiteiten die onderwijsondersteuners uitvoeren is uitgegaan van de beschikbare informatie over de verschillende onderwijsondersteunende functies. Op basis van een analyse van de beschikbare profielen is de volgende lijst met activiteiten vastgesteld:

- Voorbereiden van onderwijs(deel)taken.

- Nieuw lesmateriaal ontwikkelen of aanpassingen in bestaand lesmateriaal aanbrengen.

- Planning of lesrooster maken.

- Controleren van en rekening houden met voorschriften, reglementen en regels.

- Overleg voeren of voorgesprekken houden met leraar of docent.

- Voorgesprekken houden met leerlingen.

- Beheren en klaarmaken van lesmateriaal.

- Verlengde instructie geven aan leerlingen.

- Werkwijze en gedrag van leerlingen observeren.

- Toezien op zelfstandig werken van leerlingen.

- Leerlingen aanspreken op hun gedrag.

- Ontwikkelen van toetsen.

- Afnemen van toetsen.

- Rapporteren observaties en bevindingen aan leraar of docent.

- Gesprekken voeren met ouders.

- Leerlingen(voortgangs)registratie of schooladministratie bijhouden.

- Leerlingen beoordelen en beoordelingsgesprekken voeren met leerlingen. 
- Toezicht houden op persoonlijke verzorging van leerlingen.

- Helpen bij verzorging van leerlingen.

- Therapeutische oefeningen met leerlingen uitvoeren.

- Zorg- en behandelplannen opstellen.

- Overleggen met hulpverleners buiten de school.

- Deelnemen aan nascholing en teamcursussen.

- Deelname aan teamvergaderingen.

\section{Frequentie van het uitvoeren van activiteiten}

In figuur 3.3 wordt, voor de drie onderscheiden profielen, een overzicht gegeven van de gemiddelde frequentie waarmee de genoemde activiteiten voorkomen in het werk van onderwijsondersteuners.

\section{Figuur 3.3}

Mate waarin onderwijsondersteuners verschillende activiteiten verrichten

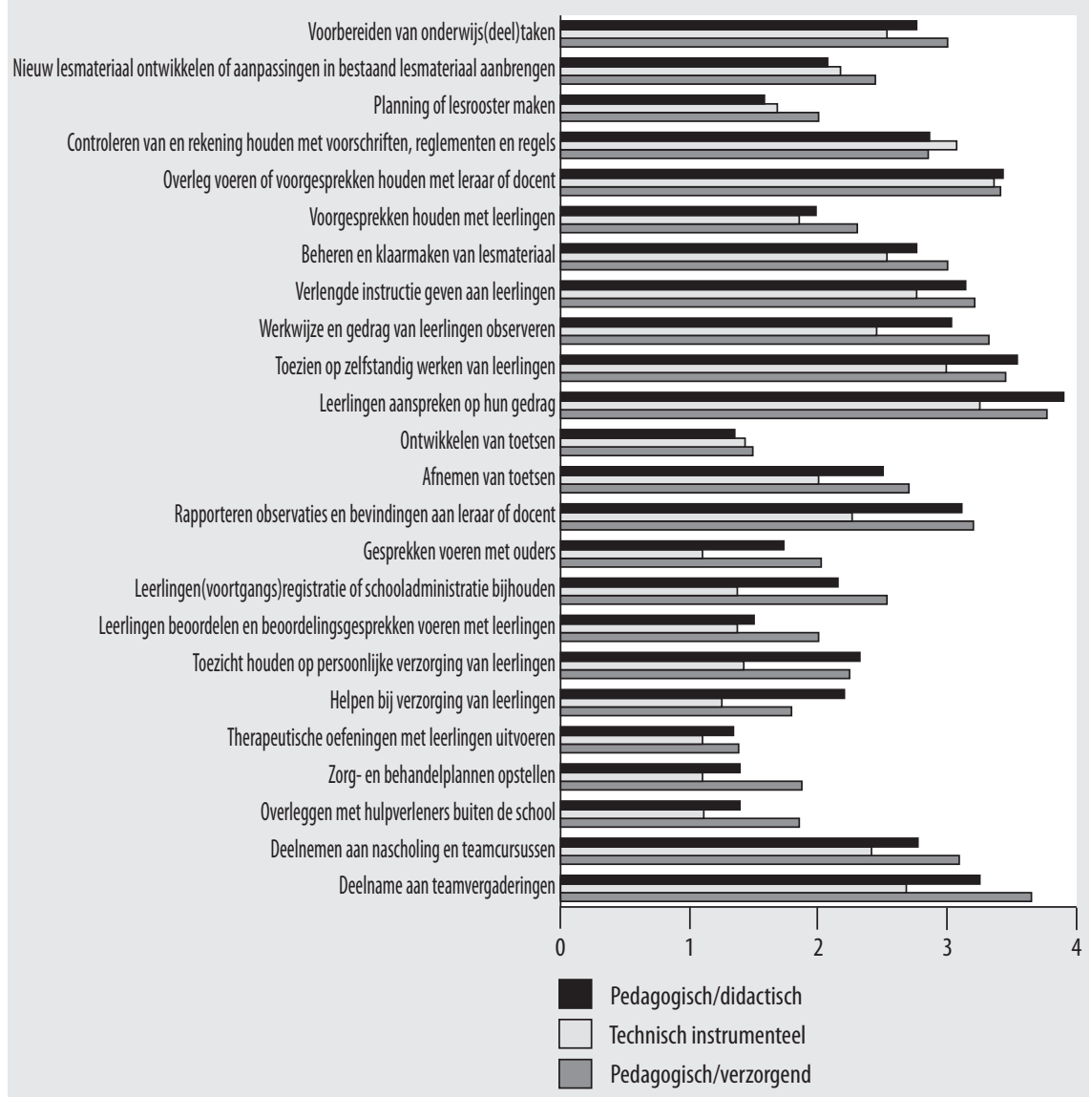

Noot: het gaat hier om de gemiddelde scores van de frequentie waarmee de activiteiten voorkomen. De frequenties zijn gemeten op een vijfpuntsschaal 
Het blijkt dat drie activiteiten relatief veel voorkomen in het werk van alle soorten onderwijsondersteuners. Het gaat hier om overleg voeren of voorgesprekken houden met leraar of docent, controleren van en rekening houden met voorschriften, reglementen en regels en leerlingen aanspreken op hun gedrag.

Activiteiten die relatief weinig voorkomen in het werk van onderwijsondersteuners zijn het ontwikkelen van toetsen, therapeutische oefeningen met leerlingen uitvoeren, zorg-en behandelplannen opstellen en overleggen met hulpverleners buiten de school. Deze activiteiten spelen in de drie onderscheiden onderwijsondersteunende functies een beperkte rol, mogelijk doordat vaak niet de onderwijsondersteuner zelf, maar de leraar of docent deze activiteiten uitvoert.

Daarnaast valt het op dat de meeste activiteiten in technisch instrumentele onderwijsondersteunende functies minder vaak voorkomen dan in pedagogisch/verzorgende en pedagogisch/didactische functies. Een uitzondering daarop vormt de activiteit controleren van en rekening houden met voorschriften, reglementen en regels. Deze activiteit komt juist wat vaker voor in het werk van technisch onderwijsondersteuners.

\section{Verantwoording afleggen over activiteiten}

Het is ook belangrijk om te weten aan wie onderwijsondersteuners verantwoording afleggen over de door hen uitgevoerde activiteiten. Daarom kijken we voor iedere activiteit of en aan wie de onderwijsondersteuner verantwoording aflegt. Daarbij zijn er drie mogelijkheden:

- De onderwijsondersteuner legt verantwoording af aan de leraar of docent.

- De onderwijsondersteuner legt verantwoording af aan de directie van de school.

- De onderwijsondersteuner legt geen verantwoording af.

In de figuren 3.4-3.6 wordt er gekeken naar het patroon van verantwoording afleggen voor de drie soorten onderwijsondersteunende functies. In figuur 3.4 wordt er ingegaan op de manieren waarop ondersteuners met pedagogisch/verzorgende functies verantwoording afleggen over de door hen uitgevoerde activiteiten. Het blijkt dat ondersteuners met deze functies voor de meeste activiteiten verantwoording afleggen aan de leraar of docent. Alleen voor de activiteiten deelnemen aan nascholing en teamcursussen en deelname aan teamvergaderingen leggen de meeste onderwijsondersteuners met pedagogisch/verzorgende functies verantwoording af aan de directie van de school waar ze werkzaam zijn. Voor vier activiteiten wordt er door onderwijsondersteuners met pedagogisch/verzorgende functies vaker dan gemiddeld geen verantwoording afgelegd: Circa $30 \%$ van de ondersteuners met deze functies legt geen verantwoording af over:

- Toezien op zelfstandig werken van leerlingen.

- Leerlingen aanspreken op hun gedrag. 
- Toezicht houden op persoonlijke verzorging van leerlingen.

- Helpen bij verzorging van leerlingen.

Voor de activiteit controleren van en rekening houden met voorschriften, reglementen en regels is het beeld wat afwijkend: Circa de helft van de onderwijsondersteuners met pedagogisch/verzorgende functies legt verantwoording af aan de leraar of docent; een kwart van de ondersteuners legt verantwoording af aan de directie van de school en de rest legt voor deze activiteit geen verantwoording af.

Figuur 3.4

Percentage ondersteuners dat verantwoording aflegt voor een bepaalde activiteit in pedagogisch/ verzorgende functies

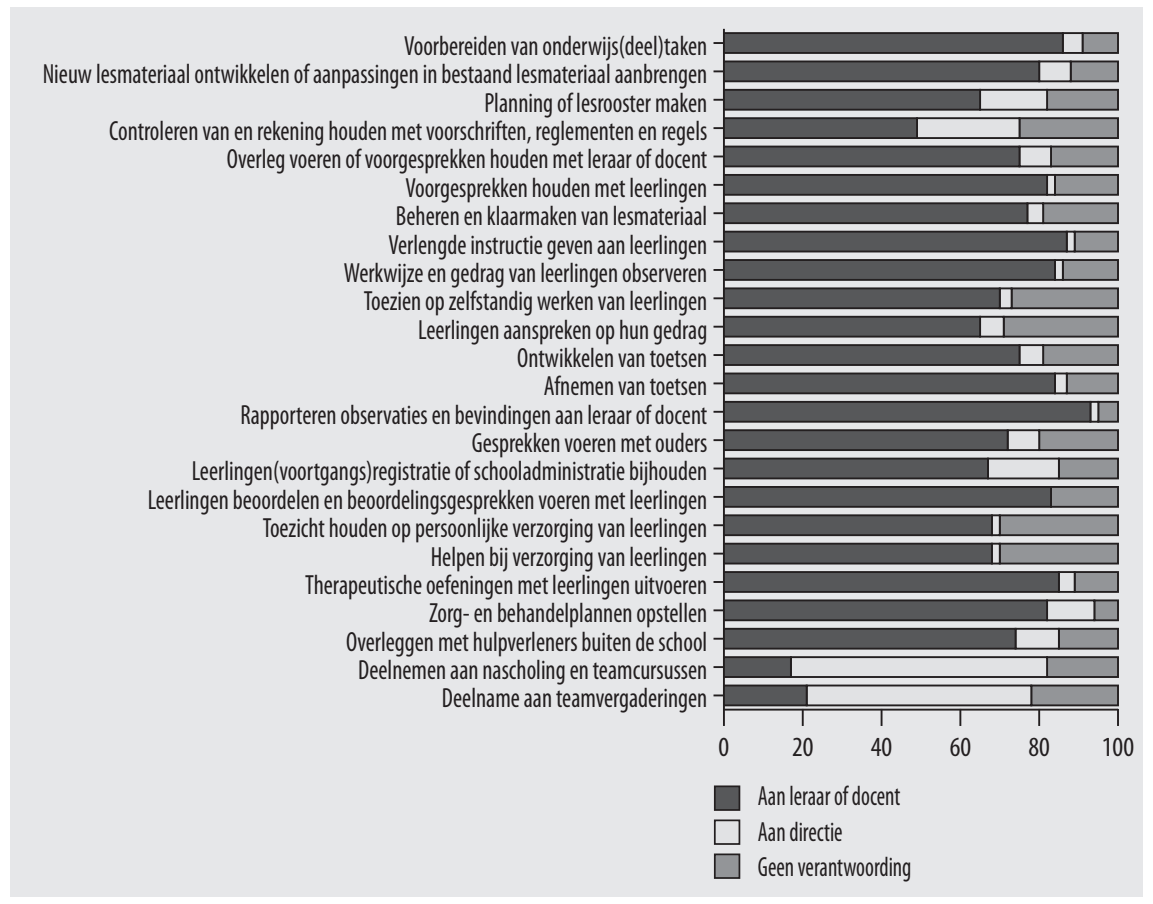

Figuur 3.5 gaat in op de manier waarop ondersteuners met technisch instrumentele functies verantwoording afleggen over hun activiteiten. Het blijkt dat de meerderheid van de onderwijsondersteuners met deze functies voor de meeste activiteiten verantwoording aflegt aan de leraar of docent. Hierop bestaan echter enkele uitzonderingen. Voor het controleren van en rekening houden met voorschriften, reglementen en regels legt slechts circa de helft van de onderwijsondersteuners met technisch instrumentele functies verantwoording af aan de leraar of docent, terwijl ruim $35 \%$ voor deze activiteit verantwoording aflegt aan de directie van de school. Voor de drie laatstgenoemde activiteiten (overleggen met hulpverleners buiten de school, deelnemen aan nascholing en teamcursussen en deelname aan teamvergaderingen) legt een meerderheid van de 
onderwijsondersteuners met technisch instrumentele functies verantwoording af aan de directie van de school waar ze werkzaam zijn.

\section{Figuur 3.5}

Percentage ondersteuners dat verantwoording aflegt voor een bepaalde activiteit in technisch instrumentele functies

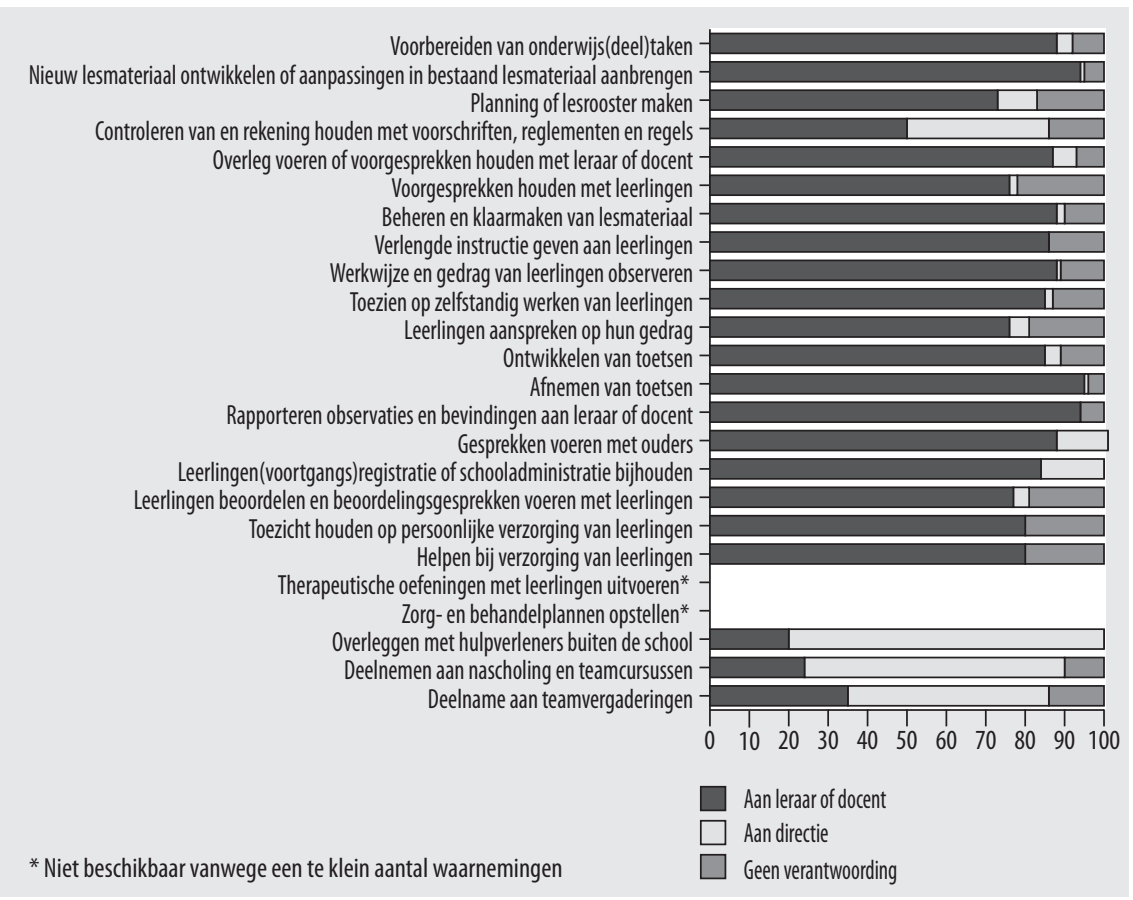

In figuur 3.6 wordt er ingegaan op de manier waarop onderwijsondersteuners met pedagogisch/didactische functies verantwoording afleggen over de activiteiten die ze uitvoeren. Ook hier blijkt dat een meerderheid van de onderwijsondersteuners met deze functies voor de meeste activiteiten verantwoording aflegt aan de leraar of docent. Voor vijf activiteiten is het beeld echter anders. Bij de activiteiten controleren van en rekening houden met voorschriften, reglementen en regels, zorg-en behandelplannen opstellen, overleggen met hulpverleners buiten de school, deelnemen aan nascholing en teamcursussen, en deelname aan teamvergaderingen legt de meerderheid van de ondersteuners met pedagogisch/didactische functies verantwoording af aan de directie. Daarnaast is het opvallend dat relatief veel van de onderwijsondersteuners in deze functies geen verantwoording aflegt aan leraar, docent of directie over het ontwikkelen van toetsen en het toezicht houden op de persoonlijke verzorging van leerlingen.

In hoeverre zijn er verschillen tussen de verschillende soorten onderwijsondersteunende functies op het vlak van de verantwoordelijkheid? De verschillen blijken beperkt. Wel komt naar voren dat ondersteuners in technisch instrumentele functies 
vaker verantwoordelijkheid afleggen aan de leraar of docent dan ondersteuners met pedagogisch/verzorgende of pedagogisch/didactische functies. Daarnaast blijkt dat ondersteuners met pedagogisch/verzorgende functies vaker verantwoording afleggen aan de leraar of docent bij het overleggen met hulpverleners buiten de school. Er is echter ook sprake van een aantal duidelijke overeenkomsten tussen de verschillende onderwijsondersteunende functies. Zo wordt er voor de activiteit controleren van en rekening houden met voorschriften, reglementen en regels in vergelijking met andere activiteiten relatief vaak verantwoording afgelegd aan de directie. Dit geldt ook voor de het deelnemen aan nascholing en teamcursussen en de deelname aan teamvergaderingen. De meerderheid van de onderwijsondersteuners legt over deze activiteiten verantwoording af aan de directie van de school waar ze werkzaam zijn.

\section{Figuur 3.6}

Percentage ondersteuners dat verantwoording aflegt voor een bepaalde activiteit in pedagogisch/ didactische functies

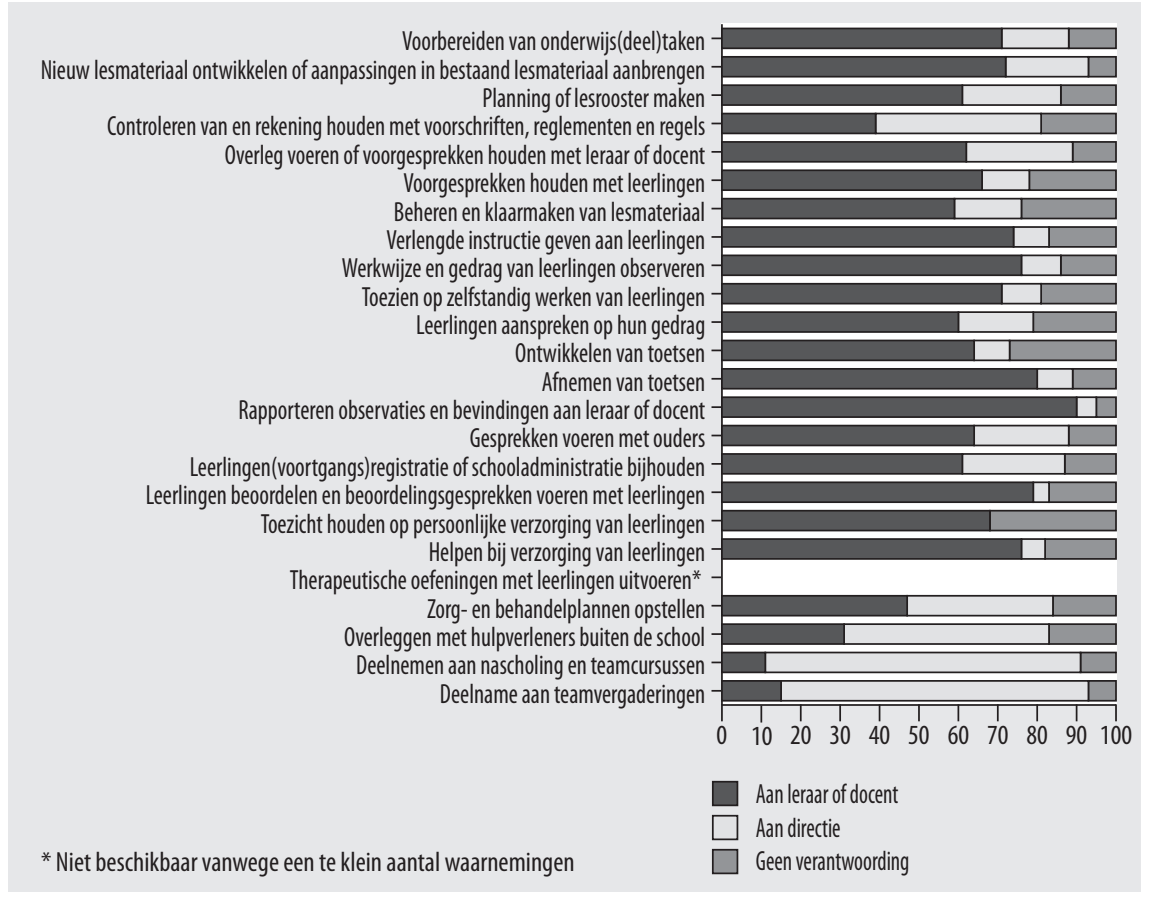

Wanneer we kijken naar het totaalbeeld, dan blijkt dat onderwijsondersteuners voor de meeste activiteiten verantwoording afleggen aan de leraar of docent. Toch zijn er tussen de verschillende soorten onderwijsondersteunende functies enkele verschillen. Zo blijkt dat dat ondersteuners met pedagogisch/verzorgende functies het vaakst geen verantwoording afleggen over de uitgevoerde activiteiten. Ondersteuners met technisch instrumentele functies leggen daarentegen juist het vaakst verantwoording af voor de activiteiten die ze verrichten. Ondersteuners met pedagogisch/didactische 
functies nemen op dit punt een middenpositie in. Ze leggen echter minder vaak dan gemiddeld verantwoording af aan de leraar of docent, maar vaker aan de directie van de school waar ze werkzaam zijn. Dit zou er op kunnen duiden dat er tussen de drie soorten onderwijsondersteunende functies ook verschillen bestaan in de manieren waarop ze worden aangestuurd. Voor ondersteuners met pedagogisch/verzorgende functies is de aansturing door leraar of docent waarschijnlijk wat minder van belang dan voor ondersteuners met technisch instrumentele onderwijsondersteunende functies.

\subsection{Benodigde competenties}

In deze paragraaf kijken we naar de mate waarin een aantal specifieke competenties vereist zijn in het werk als onderwijsondersteuner. We leggen hierbij weer de nadruk op de verschillen in de benodigde competenties tussen de drie onderscheiden functieprofielen. Op basis van een analyse van de beschikbare informatie voor onderwijsondersteunende functies en de taken en activiteiten bekijken we een aantal aspecten van competenties. Het gaat hierbij om de volgende competentie-aspecten:

\section{De kennis van:}

- Een vakgebied.

- Meerdere vakgebieden.

- De eindtermen van de eigen onderwijsinstelling.

Het vermogen om:

- Vakkennis in de praktijk toe te passen.

- Kennis over te brengen.

- Effectief mondeling te communiceren.

- Effectief schriftelijk te communiceren.

- De behoefte van leerlingen te interpreteren.

- Verschillende didactische werkvormen toe te passen.

- Ontwikkelingsmogelijkheden van kinderen optimaal te benutten.

- De eigen pedagogische opvattingen te integreren in het onderwijsleerproces.

- Maatschappelijke ontwikkelingen te integreren in het onderwijsleerproces.

- Leerlingen op verschillende manieren te beoordelen.

- Leerlingen de verzorging te geven die ze nodig hebben.

- Informatie- en communicatietechnologie te gebruiken.

- Productief met anderen samen te werken.

- Conform planning, richtlijnen of budget te werken.

- Onder druk goed te functioneren.

- Knopen door te hakken.

- Op het eigen handelen te reflecteren. 


\section{De bereidheid om:}

- Nieuwe dingen te leren.

- De nek uit te steken.

- Op te komen voor het eigen standpunt.

- Begrip te tonen voor andere standpunten.

\section{Benodigde competenties}

Het spreekt voor zich dat de meeste van de genoemde competentie-aspecten altijd in een bepaalde mate vereist zijn om het werk goed de kunnen uitvoeren. Om de nadruk te kunnen leggen op die competentie-aspecten die essentieel zijn, kijken we hier naar de aspecten die van groot belang zijn in het werk van onderwijsondersteuners. Dit wordt bereikt door de aandacht te richten op de mate waarin in het werk een hoog of een zeer hoog niveau is vereist.

Figuur 3.7 geeft per competentie-aspect een overzicht van het percentage onderwijsondersteuners dat vindt dat er, om het werk goed te kunnen uitvoeren, een hoog of zeer hoog niveau van een bepaald aspect is vereist. Ook hier kijken we weer naar de verschillen die er tussen de drie verschillende soorten onderwijsondersteunende functies bestaan.

Allereerst blijkt er bij de meeste competenties sprake te zijn van een duidelijk verschil tussen de technisch instrumentele onderwijsondersteunende functies enerzijds en de pedagogisch/verzorgende en pedagogisch/didactische functies anderzijds. $\mathrm{Bij} 20$ van de 24 competentie-aspecten is het percentage onderwijsondersteuners dat aangeeft dat er voor hun werk een hoog of zeer hoog niveau vereist is hoger bij de pedagogisch/verzorgende en pedagogisch/didactische functies dan bij de technisch instrumentele functies. Een uitzondering hierop is vakkennis. Dit competentie-aspect is juist belangrijker voor ondersteuners met technisch instrumentele functies. Andere competentie-aspecten die belangrijk zijn voor onderwijsondersteuners met een technisch instrumentele functie zijn het vermogen om vakkennis in de praktijk toe te passen, het vermogen om effectief mondeling te communiceren, het vermogen om productief met anderen samen te werken en de bereidheid om nieuwe dingen te leren. De competentieaspecten die in pedagogisch/verzorgende en pedagogisch/didactische functies belangrijk zijn overlappen grotendeels. Het gaat hier om:

- Het vermogen om effectief mondeling te communiceren.

- Het vermogen om de behoefte van leerlingen te interpreteren.

- Het vermogen om productief met anderen samen te werken.

- Het vermogen om op het eigen handelen te reflecteren.

- De bereidheid om nieuwe dingen te leren. 


\section{Figuur 3.7}

Percentage onderwijsondersteuners dat aangeeft dat er voor een goede functie-uitoefening een hoog of zeer hoog niveau van een bepaald competentie-aspect is vereist

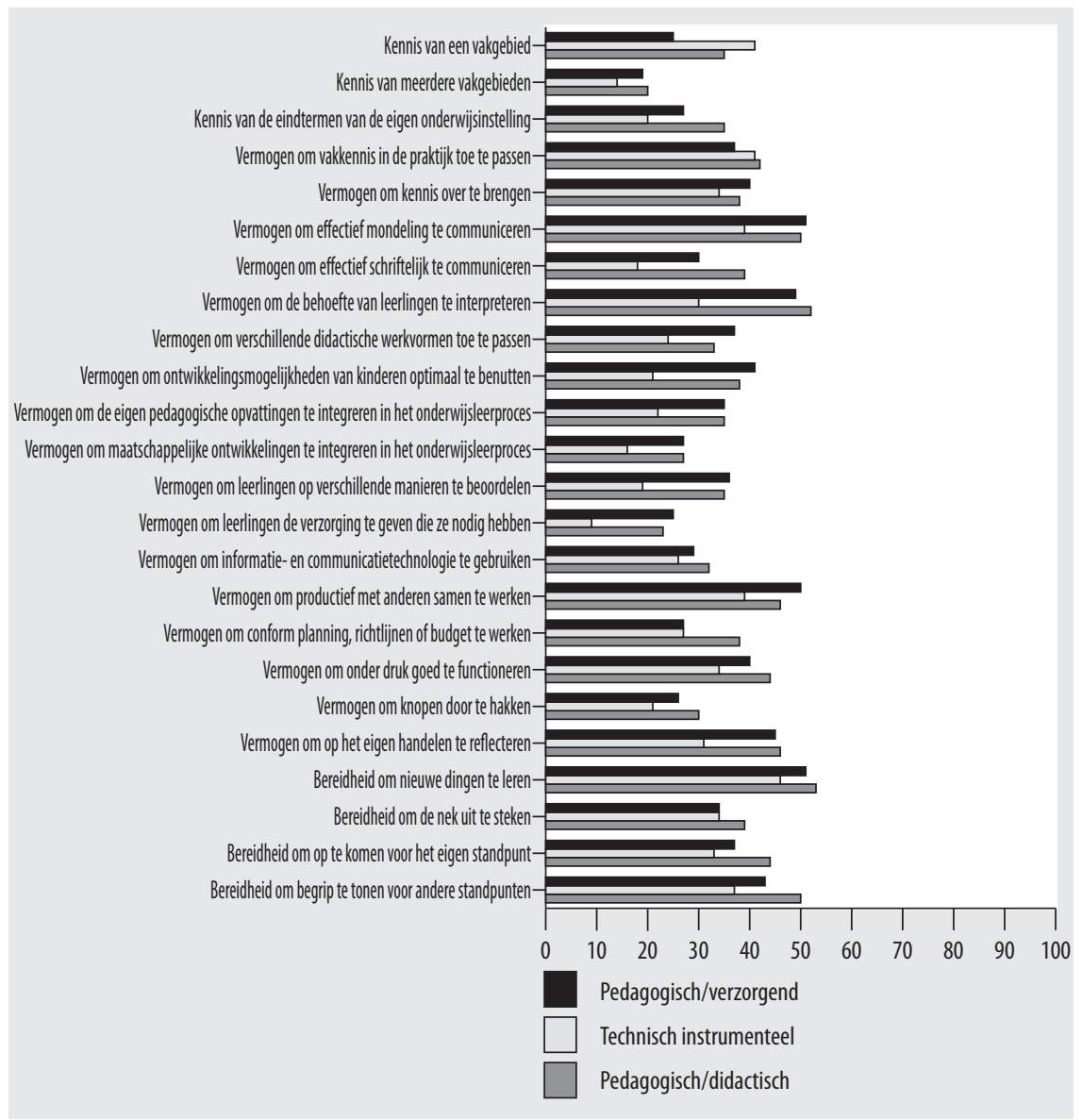

Ten slotte blijkt dat, wanneer de pedagogisch/verzorgende en pedagogisch/didactische onderwijsondersteunende functies met elkaar vergeleken worden, de verschillen tussen de competentie-aspecten groter zijn dan de verschillen tussen deze twee soorten onderwijsondersteunende functies. Dit betekent dat het op basis van deze analyse van competenties-aspecten moeilijk is om aan te geven wat de essentiële verschillen zijn tussen pedagogisch/verzorgende en pedagogisch/didactische functies.

\section{Formeel of informeel leren}

Competenties kunnen op verschillende manieren worden verworven. Dat de belangrijkste competentie-aspecten voor de drie soorten onderwijsondersteunende functies grotendeels overeenkomen betekent niet dat de er in deze drie functies sprake is van 
dezelfde leerbronnen. We kijken daarom naar de verschillen tussen de drie soorten onderwijsondersteunende functies in de manieren waarop de competentie-aspecten voornamelijk zijn geleerd. De nadruk ligt daarbij op het onderscheid tussen formeel en informeel leren. Wanneer een competentie-aspect via de initiële opleiding of tijdens een postinitiële cursus is geleerd is er sprake van formele competentieverwerving. Is een competentie-aspect tijdens het werk al doende geleerd, van een leraar of docent of op een andere manier, dan spreken we van informele competentieverwerving. Figuur 3.8 geeft een overzicht van het percentage onderwijsondersteuners dat een bepaald competentie-aspect informeel heeft geleerd.

\section{Figuur 3.8}

Percentage onderwijsondersteuners dat competentie-aspecten op informele wijze heeft aangeleerd

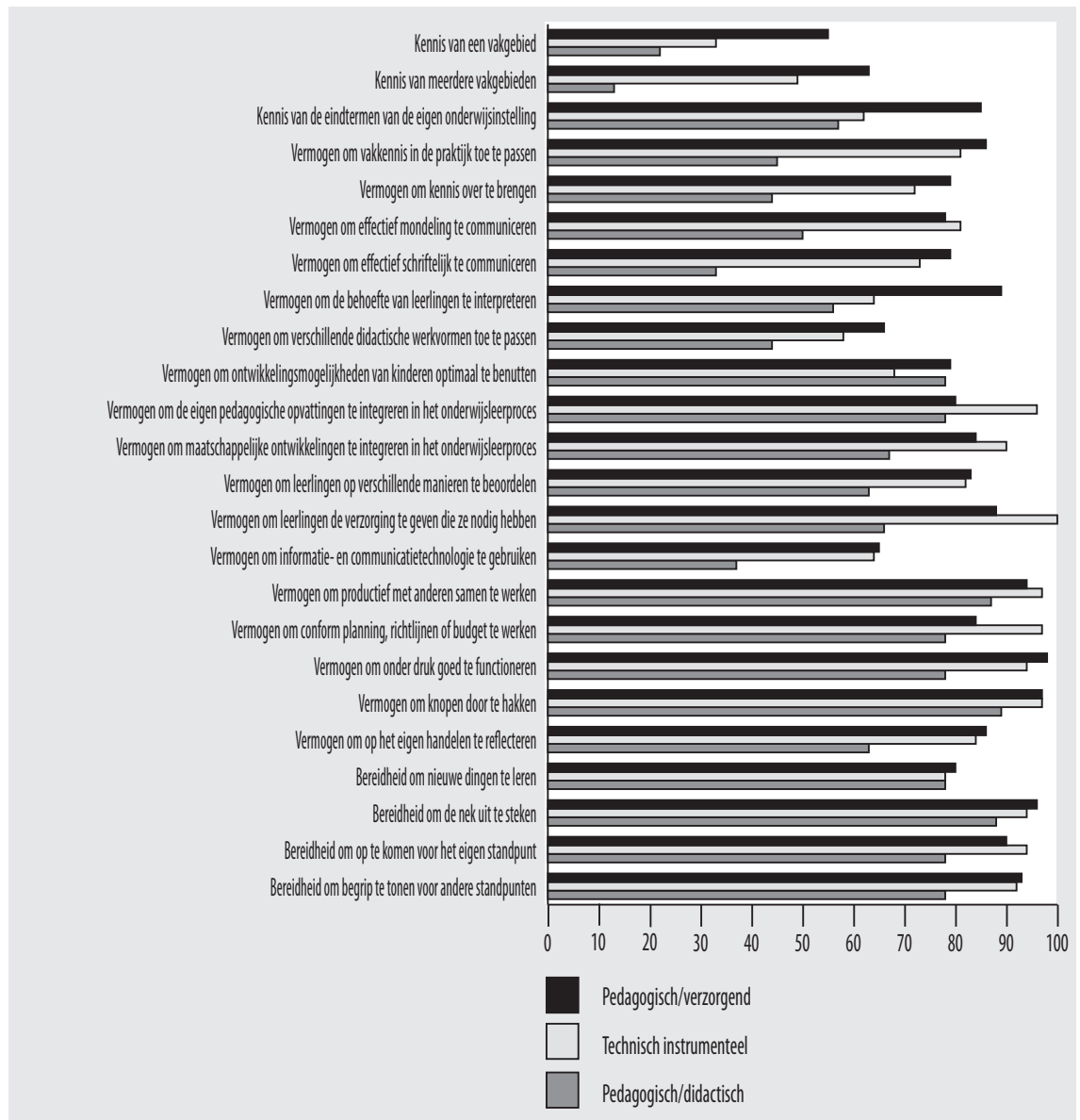


Het blijkt dat ondersteuners met pedagogisch/didactische functies minder competentie-aspecten op informele wijze hebben geleerd dan ondersteuners met andere onderwijsondersteunende functies. Onderwijsondersteuners met pedagogisch/didactische functies blijken de aspecten van competenties dus vaker via formele kanalen te leren. Daarnaast blijkt dat ondersteuners met pedagogisch/verzorgende functies voor de meeste competenties de competentie-aspecten vaker via informele weg te verwerven dan onderwijsondersteuners met een pedagogisch/didactische of technisch instrumentele functie. Het is vooral opvallend dat dit ook geldt voor de kennis van het vakgebied en de kennis van andere vakgebieden. Ondersteuners met een technisch instrumentele functie verwerven vijf competentie-aspecten vaker informeel dan de onderwijsondersteuners in een ander soort functie. Het gaat hier om:

- Het vermogen om effectief te communiceren.

- Het vermogen om de eigen pedagogische opvattingen te integreren in het onderwijsleerproces.

- Het vermogen om leerlingen de verzorging te geven die ze nodig hebben.

- Het vermogen om volgens planning, richtlijnen en budget te werken.

- De bereidheid om op te komen voor het eigen standpunt.

\section{Informeel leren en de vooropleiding}

In figuur 3.9 wordt een overzicht gegeven van de mate waarin onderwijsondersteuners met verschillende vooropleidingen de competenties die ze hebben informeel hebben geleerd. Het gaat hier om het percentage van de aspecten van competenties die op informele wijze zijn verworven.

De figuur maakt duidelijk dat voor alle vooropleidingen geldt dat de meerderheid van de competentie-aspecten (6o-80\%) voornamelijk op informele wijze is verworven. Er zijn echter ook enkele verschillen tussen de opleidingen. Onderwijsondersteuners met een TOA opleiding en diegenen die de PABO hebben afgerond hebben gemiddeld genomen minder van de competentie-aspecten informeel verworven dan onderwijsondersteuners met een andere opleiding. Voor onderwijsondersteuners met een HBO opleiding geldt juist het omgekeerde: zij hebben een groter deel van de competentieaspecten op informele wijze verworven. 
Figuur 3.9

Percentage van competentie-aspecten die op informele wijze zijn verworven

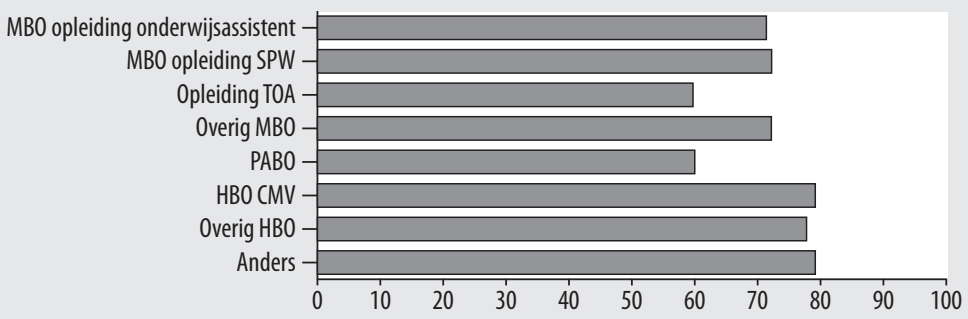

\subsection{Complexiteit}

Als laatste functiekenmerk kijken we naar een aantal factoren die gerelateerd zijn aan de complexiteit van de verschillende onderwijsondersteunende functies. In hoeverre vinden onderwijsondersteuners dat bepaalde kenmerken van hun werk bijdragen aan de complexiteit? Om de deze vraag te kunnen beantwoorden, kijken we naar het percentage onderwijsondersteuners dat vindt dat kenmerken in grote mate bijdragen aan de complexiteit van de functie. Het gaat om de volgende factoren:

- Het spanningsveld tussen wensen docent en mogelijkheden in het onderwijs(deel)proces.

- Het overtuigen van leerlingen.

- Het overtuigen van de leraar of docent.

- Didactisch correct handelen in verschillende situaties.

- Breedte van de benodigde vakinhoudelijke kennis.

- Uiteenlopende leer- en lesmethoden.

- De organisatie van de onderwijs(deel)taken.

- Werken buiten bestaande kaders.

- Werken binnen bestaande kaders.

- Tegelijkertijd verschillende doelen nastreven.

- Omgaan met belangentegenstellingen.

- Onverwachte situaties.

- Beslissingen nemen.

- Keuzes maken bij dilemma's.

- Improviseren.

- Onder verantwoordelijkheid van leraar of docent werken.

- Deelname aan commissies.

Uit figuur 3.Io blijkt dat de mate waarin onderwijsondersteuners vinden dat een factor bijdraagt aan de complexiteit samenhangt met het soort factor en met de specifieke onderwijsondersteunende functie die ze hebben. 


\section{Figuur 3.10}

Factoren die in grote mate bijdragen aan de complexiteit van de functie, \% onderwijsondersteuners

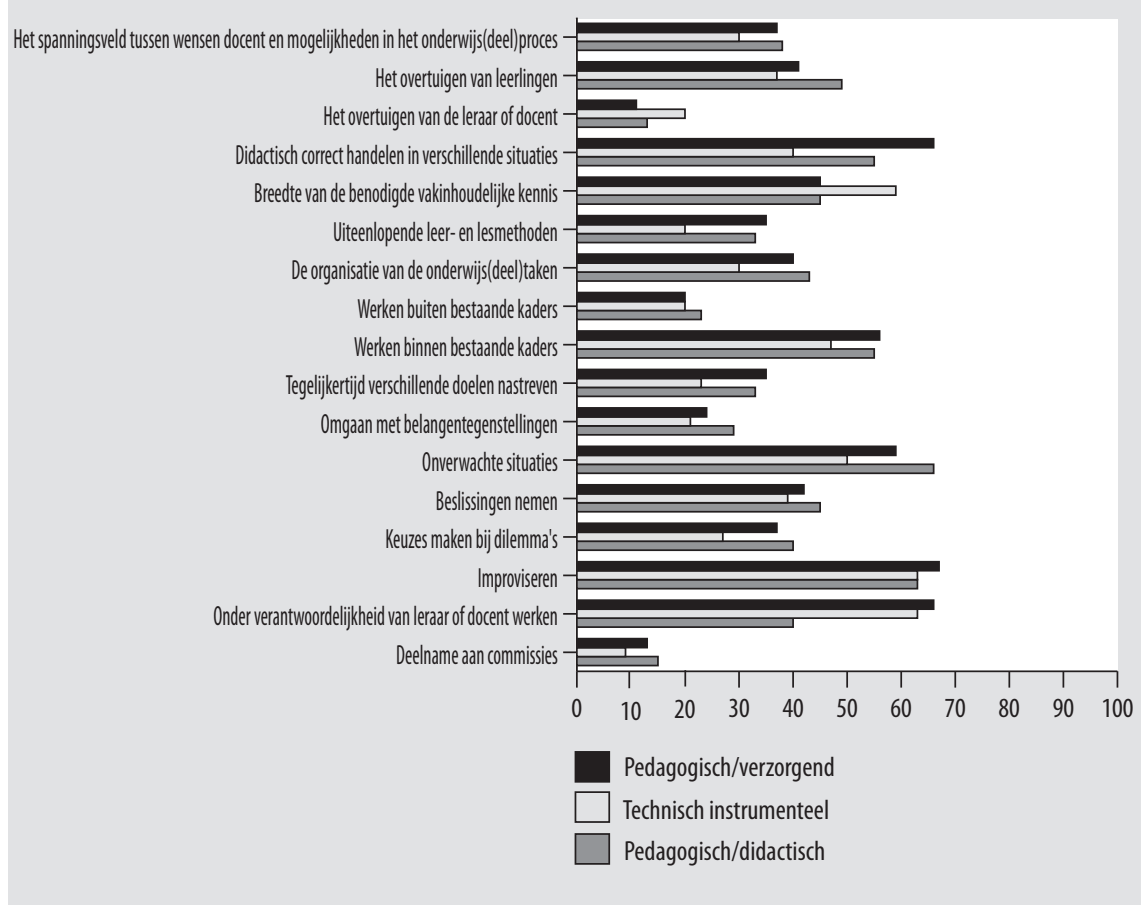

Voor ondersteuners met pedagogisch/verzorgende functies zijn er vijf factoren die vaak bijdragen aan de complexiteit van de functie. Het gaat hier om:

- Didactisch correct handelen in verschillende situaties.

- Werken binnen bestaande kaders.

- Onverwachte situaties.

- Improviseren.

- Onder verantwoordelijkheid van de leraar of docent werken.

Een meerderheid van ondersteuners met een technisch instrumentele functie vindt dat de breedte van de benodigde vakinhoudelijke kennis, onverwachte situaties, improviseren en onder verantwoordelijkheid van een leraar of docent werken hun functie complex maakt. De meerderheid van ondersteuners met pedagogisch/didactische functies vindt dat didactisch correct handelen in verschillende situaties, werken binnen bestaande kaders, onverwachte situaties en improviseren zorgen voor complexiteit in hun werk. Deze factoren komen grotendeels overeen met de factoren waarvan ondersteuners met pedagogisch/verzorgende functies vinden dat ze in grote mate bijdragen aan de complexiteit van de functie. Wel is het opmerkelijk dat ondersteuners met pedagogisch/didactische functies het onder verantwoordelijkheid van een leraar of 
docent werken veel minder vaak zien als een factor die in grote mate bijdraagt aan de complexiteit dan ondersteuners met een pedagogisch/verzorgende functie. Dit houdt wellicht verband met het feit dat ondersteuners met pedagogisch/didactische functies meer taken zelfstandig uitvoeren dan ondersteuners met andere ondersteunende functies en dat een relatief groot gedeelte van hen een opleiding op HBO-niveau heeft afgerond. Het feit dat relatief veel ondersteuners met pedagogisch/verzorgende functies vinden dat het werken onder verantwoordelijkheid van een leraar of docent in grote bijdraagt aan de complexiteit van het werk zou er op kunnen duiden dat ondersteuners met deze functies de mogelijkheden van samenwerking nog onvoldoende in hun werk benutten.

Ten slotte blijken drie factoren volgens een grote meerderheid van de onderwijsondersteuners de complexiteit van hun functie niet te vergroten: het overtuigen van de leraar of docent, werken buiten bestaande kaders, omgaan met belangentegenstellingen en deelname aan commissies.

\subsection{Verschillen tussen onderwijssectoren}

Naast mogelijke verschillen tussen verschillende soorten onderwijsondersteunende functies kunnen er ook verschillen bestaan tussen de onderwijssectoren. In deze paragraaf bespreken we de verschillen tussen het primair onderwijs (PO), het speciaal primair onderwijs (SPO), het voortgezet onderwijs (VO), het speciaal voortgezet onderwijs (SVO) en de sector beroeps en volwasseneneducatie (BVE) op het vlak van de taken die onderwijsondersteuners uitvoeren, de activiteiten en de vereiste competenties. We bepreken hier alleen de meest opmerkelijke verschillen.

Taken

Het voorbereidings - en afrondingswerkzaamheden van lessen uitvoeren komt relatief vakk voor in het takenpakket van onderwijsondersteuners in het primair onderwijs en de BVE, terwijl deze taak minder van belang is voor onderwijsondersteuners in het speciaal primair onderwijs. Drie taken komen relatief vaak voor in het werk van onderwijsondersteuners in het speciaal primair en voortgezet onderwijs, terwijl ze een minder grote rol spelen in het werk van onderwijsondersteuners in het voortgezet onderwijs en de BVE: onderdelen van het onderwijsprogramma uitvoeren, bijdragen aan een goed pedagogisch klimaat en extra-curriculaire activiteiten organiseren. Het begeleiden van individuele leerlingen tijdens het onderwijsproces en het begeleiden van kleine groepen leerlingen tijdens het onderwijsproces komt relatief vaak voor in het werk van ondersteuners in het normale en speciaal primair onderwijs, terwijl deze taken een veel minder grote rol spelen in het voortgezet onderwijs en in de BVE. De volgende drie taken zijn in het primair onderwijs, het speciaal primair onderwijs en het speciaal voortgezet onderwijs belangrijker dan in het voortgezet onderwijs en de BVE: individuele leerlingen buiten het onderwijsproces begeleiden, kleine groepen leerlingen buiten 
het onderwijsproces begeleiden en leerlingen beoordelen en toetsen. Voor wat betreft practica en experimenten faciliteren, leerlingen tijdens practica en experimenten begeleiden en leerlingen bij het inoefenen van beroepsvaardigheden begeleiden is het beeld juist omgekeerd. Deze taken komen vaker voor in het voortgezet onderwijs en de BVE, terwijl ze minder vaak voorkomen in het werk van onderwijsondersteuners die in het primair onderwijs of in het speciaal primair onderwijs werkzaam zijn. Het bieden van zorg (fysiek of sociaal-emotioneel) komt relatief vaak voor in het speciaal primair en voortgezet onderwijs en speelt een minder grote rol in het voortgezet onderwijs en de BVE. De verschillen in de mate waarin onderwijsondersteuners administratieve werkzaamheden uitvoeren zijn beperkt, maar onderwijsondersteuners in het primair en speciaal primair onderwijs voeren hebben deze taak minder vaak in hun takenpakket dan ondersteuners die werkzaam zijn in de andere onderwijssectoren.

\section{Activiteiten}

Er zijn tussen de onderwijssectoren een aantal verschillen in de mate waarin onderwijsondersteuners verschillende activiteiten uitvoeren. Zo blijkt dat onderwijsondersteuners werkzaam in het speciaal primair of voortgezet onderwijs de volgende activiteiten vaker uitvoeren dan onderwijsondersteuners in andere sectoren:

- Voorbereiden van onderwijs(deel)taken.

- Verlengde instructie geven aan leerlingen.

- Werkwijze en gedrag van leerlingen observeren.

- Toezien op zelfstandig werken van leerlingen.

- Leerlingen aanspreken op hun gedrag.

- Toezicht houden op persoonlijke verzorging van leerlingen.

- Helpen bij verzorging van leerlingen.

- Therapeutische oefeningen met leerlingen uitvoeren.

- Deelnemen aan nascholing en teamcursussen.

- Deelname aan teamvergaderingen.

In het primair onderwijs komen de volgende activiteiten relatief vaak voor in het werk van onderwijsondersteuners:

- Nieuw lesmateriaal ontwikkelen of aanpassingen in bestaand lesmateriaal aanbrengen.

- Controleren van en rekening houden met voorschriften, reglementen en regels.

- Overleg voeren of voorgesprekken houden met leraar of docent.

- Beheren en klaarmaken van lesmateriaal.

- Afnemen van toetsen.

- Gesprekken voeren met ouders.

- Leerlingen(voortgangs)registratie of schooladministratie bijhouden.

- Leerlingen beoordelen en beoordelingsgesprekken voeren met leerlingen. 
- Therapeutische oefeningen met leerlingen uitvoeren.

- Zorg- en behandelplannen opstellen.

- Overleggen met hulpverleners buiten de school.

De activiteiten planning of lesrooster maken, voorgesprekken houden met leerlingen en het ontwikkelen van toetsen komen relatief vaak voor in het werk van onderwijsondersteuners die werkzaam zijn in het speciaal voortgezet onderwijs.

Wanneer we kijken naar activiteiten die relatief weinig voorkomen in het werk van onderwijsondersteuners dan blijkt dat een aantal activiteiten voor onderwijsondersteuners die werkzaam zijn in het voortgezet onderwijs en de BVE relatief weinig worden uitgevoerd. Het gaat hier om:

- Voorbereiden van onderwijs(deel)taken.

- Controleren van en rekening houden met voorschriften, reglementen en regels.

- Overleg voeren of voorgesprekken houden met leraar of docent.

- Voorgesprekken houden met leerlingen.

- Beheren en klaarmaken van lesmateriaal.

- Verlengde instructie geven aan leerlingen.

- Werkwijze en gedrag van leerlingen observeren.

- Gesprekken voeren met ouders.

- Toezicht houden op persoonlijke verzorging van leerlingen.

- Helpen bij verzorging van leerlingen.

- Therapeutische oefeningen met leerlingen uitvoeren.

- Zorg- en behandelplannen opstellen.

- Overleggen met hulpverleners buiten de school.

Onderwijsondersteuners die werkzaam zijn in het voortgezet onderwijs of de BVE voeren de activiteiten leerlingen aanspreken op hun bedrag en deelname aan teamvergaderingen relatief weinig uit. Voor onderwijsondersteuners werkzaam in het voortgezet onderwijs zijn het rapporteren van observaties en bevindingen aan leraar of docent en de deelname aan nascholing of teamcursussen minder vaak van belang. In het primair onderwijs, ten slotte, zien onderwijsondersteuners minder vaak toe op het zelfstandig werken van leerlingen dan in andere onderwijssectoren.

\section{Competenties}

Ook wat betreft de benodigde competenties in het werk zijn er tussen de verschillende onderwijssectoren een aantal duidelijke verschillen. Zo blijkt dat er voor onderwijsondersteuners in het gewone en in het speciaal primair onderwijs vaker dan in de andere onderwijssectoren een hoog of zeer hoog niveau is vereist voor de volgende competentie-aspecten: 
- Kennis van meerdere vakgebieden.

- Kennis van de eindtermen van de eigen onderwijsinstelling.

- Vermogen om vakkennis in de praktijk toe te passen.

- Vermogen om kennis over te brengen.

- Vermogen om effectief mondeling te communiceren.

- Vermogen om verschillende didactische werkvormen toe te passen.

- Vermogen om ontwikkelingsmogelijkheden van kinderen optimaal te benutten.

- Vermogen om productief met anderen samen te werken.

In het speciaal primair en voortgezet onderwijs wordt er vaak een hoog of zeer hoog niveau vereist voor de volgende competentie-aspecten:

- Kennis van een vakgebied.

- Vermogen om de eigen pedagogische opvattingen te integreren in het onderwijsleerproces.

- Vermogen om leerlingen op verschillende manieren te beoordelen.

- Vermogen om leerlingen de verzorging te geven die ze nodig hebben.

- Vermogen om op het eigen handelen te reflecteren.

- Bereidheid om begrip te tonen voor andere standpunten.

In het voortgezet onderwijs wordt het vaakst een hoog of zeer hoog niveau vereist voor het aspect: vermogen om informatie- en communicatietechnologie te gebruiken. In het primair onderwijs wordt er relatief vaak naar een hoog of zeer hoog niveau gevraagd voor het vermogen om maatschappelijke ontwikkelingen te integreren in het onderwijsleerproces.

Er zijn ook een aantal competentie-aspecten waarvoor er in bepaalde onderwijssectoren minder vaak naar een hoog of zeer hoog niveau wordt gevraagd. Zo is er voor de volgende competentie-aspecten minder vakk een hoog of zeer hoog niveau vereist in het voortgezet onderwijs en de BVE dan in de andere onderwijssectoren:

- Kennis van meerdere vakgebieden.

- Vermogen om kennis over te brengen.

- Vermogen om effectief mondeling te communiceren.

- Vermogen om effectief schriftelijk te communiceren.

- Vermogen om de behoefte van leerlingen te interpreteren.

- Vermogen om verschillende didactische werkvormen toe te passen.

- Vermogen om ontwikkelingsmogelijkheden van kinderen optimaal te benutten.

- Vermogen om de eigen pedagogische opvattingen te integreren in het onderwijsleerproces.

- Vermogen om leerlingen op verschillende manieren te beoordelen.

- Bereidheid om nieuwe dingen te leren. 
- Bereidheid om op te komen voor het eigen standpunt.

- Bereidheid om begrip te tonen voor andere standpunten.

Verder blijkt dat in het speciaal voortgezet onderwijs minder vaak een hoog of zeer hoog niveau wordt vereist op het vlak van informatie en communicatietechnologie en dat wat betreft het vermogen om knopen door te hakken en de bereidheid om de nek uit te steken in de BVE veel minder vaak een hoog of zeer hoog niveau vereist is dan in de andere onderwijssectoren.

\subsection{Conclusies}

In dit hoofdstuk is een groot aantal kenmerken van onderwijsondersteunende functies de revue gepasseerd. Er is gekeken naar de verschillen tussen pedagogisch/verzorgende, technisch instrumentele en pedagogisch/didactische functies op de volgende punten:

- De taken in de functie.

- De mate van zelfstandigheid.

- De activiteiten in de functie.

- De manieren waarop er verantwoording wordt afgelegd over de taken.

- De vereiste competenties.

- De mate waarin de vereiste competenties informeel zijn aangeleerd.

- De complexiteit van de functie.

Aan het eind van dit hoofdstuk is onderzocht in hoeverre er tussen de verschillende sectoren in het onderwijs verschillen zijn in de taken, de activiteiten en de vereiste competenties van onderwijsondersteuners.

Voor wat betreft de verrichte taken blijkt dat de verschillen tussen pedagogisch/verzorgende en pedagogisch/didactische functies relatief beperkt zijn. Er zijn echter wel verschillen tussen deze functies en de technisch instrumentele functies. De meeste taken komen minder voor in het takenpakket van technisch onderwijsondersteuners. Uitzondering hierop vormen twee taken op het vlak van practica en experimenten. Deze taken komen juist vaker voor in het takenpakket van ondersteuners met technisch instrumentele functies. De mate van zelfstandigheid bij het uitvoeren van taken is het grootst voor onderwijsondersteuners met pedagogisch/didactische functies en het laagst voor ondersteuners met pedagogisch/verzorgende functies.

Wanneer er wordt gekeken naar de activiteiten die onderwijsondersteuners in hun werk uitvoeren, dan blijkt allereerst dat voor vrijwel alle activiteiten geldt dat ondersteuners met technisch instrumentele functies ze minder frequent uitvoeren dan ondersteuners in andere functies. Voor de andere twee onderwijsondersteunende functies (pedagogisch/verzorgend en pedagogisch/didactisch) zijn de verschillen tussen de onder- 
scheiden activiteiten groter dan de verschillen tussen deze twee soorten onderwijsondersteuners. Ook blijkt dat een drietal activiteiten over de gehele linie van belang is. Het gaat hier om overleg voeren of voorgesprekken houden met leraar of docent, controleren van en rekening houden met voorschriften, reglementen en regels en leerlingen aanspreken op hun gedrag.

Het blijkt dat onderwijsondersteuners over de meeste activiteiten verantwoording afleggen aan de leraar of docent. De uitzonderingen hierop zijn het volgen van nascholing of teamcursussen en de deelname aan teamvergaderingen. Voor deze activiteiten leggen onderwijsondersteuners vooral verantwoording af aan de directie van de school waar ze werkzaam zijn. Ondersteuners met pedagogisch/verzorgende functies leggen minder vaak verantwoording af over de uitgevoerde activiteiten dan ondersteuners met technisch instrumentele functies. Ondersteuners met pedagogisch/didactische functies nemen een middenpositie in, maar ze leggen minder vaak verantwoording af aan de leraar of docent; deze groep legt relatief vaak verantwoording af aan de directie van de school waar ze werkzaam zijn.

Wanneer er wordt gekeken naar de competenties die voor onderwijsondersteunende functies vereist zijn, dan blijkt dat in pedagogisch/verzorgende en pedagogisch/didactische functies de verschillen tussen de competentie-aspecten onderling groter zijn dan de verschillen tussen de deze onderwijsondersteunende functies. Ook blijkt dat de competentie-aspecten waarvoor in het werk een hoog of zeer hoog niveau vereist is voor pedagogisch/verzorgende en pedagogisch/didactische functies grotendeels overlappen. Dit maakt het moeilijk om op basis van de vergelijking tussen de competentie-aspecten aan te geven wat de essentiële verschillen zijn tussen deze twee soorten onderwijsondersteunende functies. Er blijken tussen deze functies overigens wel verschillen te bestaan in de mate waarin de competentie-aspecten informeel zijn aangeleerd. Ondersteuners met pedagogisch/verzorgende functies hebben veel aspecten van competenties vaker informeel geleerd dan ondersteuners met pedagogisch/didactische of technisch instrumentele functies.

Uit de analyse van factoren die bijdragen aan de complexiteit van de functie komt naar voren dat er een beperkt aantal factoren is dat in grote mate aan deze complexiteit bijdraagt. Het gaat hier om didactisch correct handelen in verschillende situaties, werken binnen bestaande kaders, onverwachte situaties, improviseren en onder verantwoordelijkheid van de leraar of docent werken. Het blijkt verder dat er tussen de verschillende onderwijsondersteunende functies wel enkele verschillen bestaan, maar er kan niet geconcludeerd worden dat de analyse van de complexiteit van de functies wijst op grote verschillen tussen de drie onderscheiden ondersteunende functies.

Ook tussen de verschillende onderwijssectoren zijn er verschillen in de taken, de activiteiten en de benodigde competenties van onderwijsondersteuners. Het gaat hier met name om verschillen tussen het voortgezet onderwijs en de BVE enerzijds, en het primair onderwijs en het speciaal onderwijs anderzijds. 
De analyses in dit hoofdstuk hebben laten zien dat er geen sprake is van grote verschillen in de functiekenmerken van pedagogisch/verzorgende en pedagogisch/ didactische functies. Er bleken wel enkele verschillen te zijn tussen deze functies en technisch instrumentele functies. Toch zijn de geconstateerde verschillen in taken, zelfstandigheid, activiteiten, verantwoordelijkheid, competenties en complexiteit in het algemeen vrij beperkt. Dit zou erop kunnen wijzen dat er tussen de drie verschillende soorten onderwijsondersteunende functies ook veel overeenkomsten zijn. De beperkte verschillen in de functiekenmerken zouden echter ook kunnen betekenen dat er mogelijkheden zijn om de gehanteerde indeling in drie soorten onderwijsondersteunende functies nader uit te werken. Hierop gaan we in hoofdstuk 5 nader in. 


\section{Ondersteuners in het Nederlandse onderwijs}

\subsection{Inleiding}

In dit hoofdstuk kijken we naar de positie van onderwijsondersteuners in het Nederlandse onderwijs. Daarbij kijken we naar de eventuele verschillen tussen de onderscheiden onderwijsondersteuners en de eventuele verschillen tussen de verschillende onderwijssectoren. Voor wat betreft de verschillende soorten onderwijsondersteuners sluiten we aan bij de indeling in drie onderwijsondersteunende functies zoals die eerder door het LPBO is opgesteld (zie ook hoofdstuk 2). Voor wat betreft de onderwijssectoren kijken we naar:

- Het primair onderwijs (PO).

- Het speciaal primair onderwijs (SPO).

- Het voortgezet onderwijs (VO).

- Het speciaal voortgezet onderwijs (SVO).

- De sector beroeps en volwasseneneducatie (BVE).

- De sector overig.

Allereerst kijken we in paragraaf 4.2 naar de soort onderwijsondersteuners die er momenteel in de verschillende onderwijssectoren werkzaam zijn. Vervolgens gaan we in paragraaf 4.3 in op de positie van onderwijsondersteuners in het onderwijs. Daarbij gaan we in op de verhouding tussen het aantal onderwijsondersteuners en het aantal leerlingen op scholen en de verhouding tussen het aantal onderwijsondersteuners en het totale personeelsbestand. Ook kijken we naar de lengte van de loopbaan van onderwijsondersteuners en het aantal vakken waarbij ze in hun werk betrokken zijn.

In paragraaf 4.4 kijken we naar de opleidingsachtergrond van onderwijsondersteuners: welke vooropleiding hebben onderwijsondersteuners en in hoeverre sluit hun opleiding aan bij het werk dat ze hebben? Daarna gaan we in paragraaf 4.5 in op de mate waarin de capaciteiten van onderwijsondersteuners in het werk benut worden, of onderwijsondersteuners vinden dat ze bepaalde kennis missen voor hun werk en of de kennis en vaardigheden ook bruikbaar zijn buiten de school waar men werkzaam is. We sluiten het hoofdstuk in paragraaf 4.6 af met enkele resumerende conclusies. 
De in het eerste deel van dit hoofdstuk gepresenteerde informatie is gebaseerd op meningen en feiten die voortkomen uit de enquête onder de schooldirecteuren, de leraren of docenten en de onderwijsondersteuners zelf. Op deze wijze wordt er zorg voor gedragen dat de uitkomsten betrekking hebben op verschillende partijen die betrokken zijn bij onderwijsondersteunende functies. De cijfers over de opleidingachtergrond, de lengte van de loopbaan, de aansluiting tussen functie en opleiding, de benutting van kennis, en de mogelijke kennistekorten hebben alleen betrekking op de antwoorden van de onderwijsondersteuners zelf.

\subsection{Onderwijsondersteuners in de verschillende onderwijssectoren}

Figuur 4.I geeft een overzicht van de samenstelling van het totaal aantal onderwijsondersteuners per onderwijssector. Zowel in het gewone als het speciale primaire onderwijs (PO en SPO) vormen de pedagogisch/verzorgende onderwijsondersteuners verreweg de grootste groep. $80 \%$ van de onderwijsondersteuners heeft een pedagogisch/verzorgende onderwijsondersteunende functie. Binnen deze onderwijssectoren werken vrijwel geen onderwijsondersteuners met een technisch instrumentele onderwijsondersteunende functie, terwijl het aandeel van onderwijsondersteuners met een pedagogisch/didactische functies beperkt is.

\section{Figuur 4.1}

Soorten onderwijsondersteuners per onderwijssector, in \%

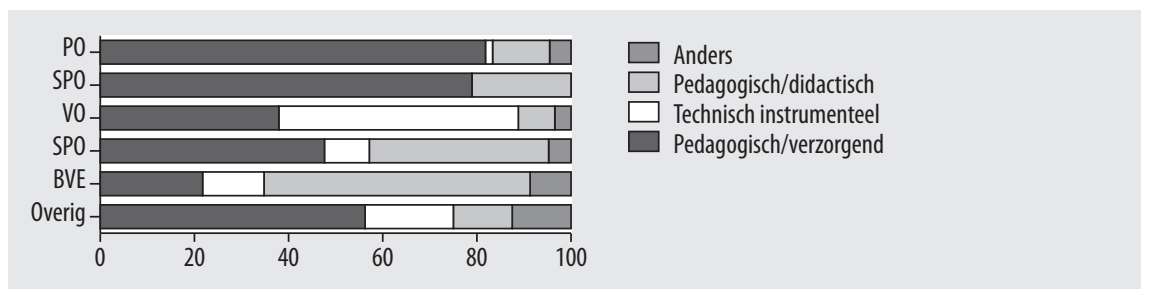

In het voortgezet onderwijs (VO) valt het grote aandeel van de technisch instrumentele onderwijsondersteuners op. Bijna de helft van het totaal aantal ondersteuners in het voortgezet onderwijs is technisch onderwijsondersteuner (TOA). In het speciaal voortgezet onderwijs (SVO) ligt daarentegen de nadruk op onderwijsondersteunende functies van pedagogische aard. Bijna $90 \%$ van het totaal aantal werkzame onderwijsondersteuners in deze sector heeft een pedagogisch/verzorgende of een pedagogisch/ didactische functie.

In de BVE sector werken de onderwijsondersteuners vooral in pedagogisch/didactische functies: ruim 50\% van de ondersteuners in deze sector heeft een dergelijke functie. Bij andere scholen (de sector 'overig') gaat het meestal om combinaties van eerder genoemde sectoren, zoals bijvoorbeeld scholen die zowel tot het primair als het voortgezet onderwijs behoren. In dergelijke scholen is het aandeel van pedagogisch/ 
verzorgende onderwijsondersteuners het grootst. Daarnaast heeft circa één op de vijf onderwijsondersteuners een technisch instrumentele functie. Ook valt het op dat het aandeel van onderwijsondersteunende functies dat niet behoort tot één van de drie profielen in andere scholen met IO\% het grootst is. Deze scholen hebben dus vaker de beschikking over onderwijsondersteuners die niet behoren tot één van de drie profielen voor onderwijsondersteunende functies. Het blijkt dat het hierbij in de praktijk veelal gaat om zogenaamde combifuncties, waarbij de werkzaamheden als onderwijsondersteuner worden gecombineerd met activiteiten die niet direct gerelateerd zijn aan het primaire proces, zoals bijvoorbeeld administratie of ICT-ondersteuning.

\subsection{De positie van onderwijsondersteuners in het onderwijs}

Hoe staat het met de positie van onderwijsondersteuners binnen de scholen waar ze werkzaam zijn? In figuur 4.2 kijken we, voor de verschillende onderwijssectoren allereerst naar de leerling-onderwijsondersteuner ratio. Het valt direct op dat het aantal leerlingen per onderwijsondersteuner in het speciaal onderwijs veel kleiner is dan het aantal leerlingen per onderwijsondersteuner in het gewone onderwijs. In het speciaal primair onderwijs is er één onderwijsondersteuner per 25 leerlingen. In het speciaal voortgezet onderwijs is er één onderwijsondersteuner per 44 leerlingen. In het gewone onderwijs is die verhouding heel anders. Op basisscholen is er gemiddeld één onderwijsondersteuner op I57 leerlingen; in het voorgezet onderwijs (VO) bedraagt het aantal leerlingen per onderwijsondersteuner ruim 200. Ook in de BVE is het aantal onderwijsondersteuners in relatie tot het totaal aantal leerlingen klein. Het gemiddeld aantal leerlingen per onderwijsondersteuner bedraagt in deze sector I64. In scholen die niet behoren tot één van de eerder genoemde onderwijssectoren zijn er voor iedere onderwijsondersteuner circa Ioo leerlingen. De grote verschillen tussen de scholen voor speciaal onderwijs en het gewone onderwijs duiden erop dat onderwijsondersteuners binnen het speciaal onderwijs een prominentere positie innemen dan onderwijsondersteuners in het gewone onderwijs.

\section{Figuur 4.2}

Gemiddeld aantal leerlingen per onderwijsondersteuner, per onderwijssector

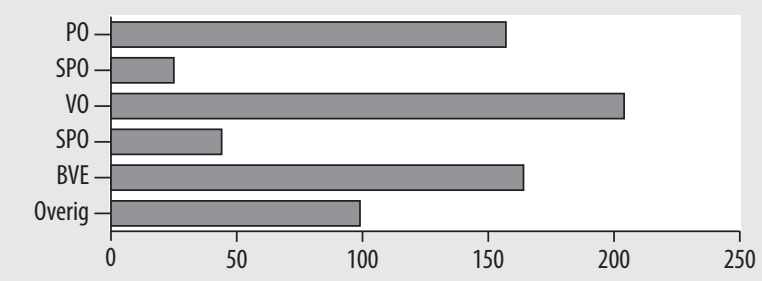


Om te kunnen bezien of er tussen de onderwijssectoren ook verschillen zijn wat betreft de verhouding tussen het totaal aantal onderwijsondersteuners en het totale personeelsbestand van de scholen, geeft figuur 4.3, voor de verschillende onderwijssectoren, een overzicht van het gemiddeld aantal personeelsleden per onderwijsondersteuner. Ook hier valt de positie van het speciaal onderwijs op. In zowel het speciaal primair onderwijs (SPO) als het speciaal voortgezet onderwijs (SVO) is het aandeel van onderwijsondersteuners in het totale personeelsbestand veel groter dan in het gewone primaire onderwijs (PO) en voortgezet onderwijs (VO). In het speciaal onderwijs is er gemiddeld één onderwijsondersteuner op de 7-8 personeelsleden. In het gewone primair onderwijs (PO) is één op de I4 personeelsleden onderwijsondersteuner, terwijl in er in het gewone voortgezet onderwijs (VO) sprake is van een verhouding van één op 2I. In de BVE heeft gemiddeld één op de I2 personeelsleden een onderwijsondersteunende functie. In andere scholen bedraagt deze verhouding circa I op 9. Ook hier blijkt dus dat de inzet van onderwijsondersteuners in het speciaal onderwijs groter is dan in het gewone onderwijs.

\section{Figuur 4.3}

Gemiddeld aantal personeelsleden per onderwijsondersteuner, per onderwijssector

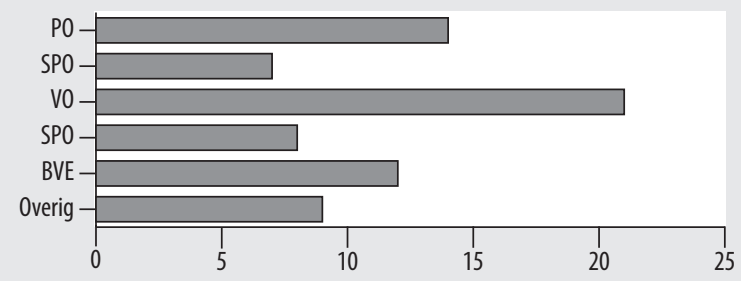

Het is de vraag of er tussen de drie onderscheiden soorten onderwijsondersteuners ook verschillen zijn in de leerling-onderwijsondersteuner ratio's. Figuur 4.4 laat zien dat de verschillen tussen de drie soorten onderwijsondersteuners duidelijk minder groot zijn dan de verschillen tussen de onderwijssectoren. Tussen pedagogisch/verzorgende, pedagogisch/didactische en overige onderwijsondersteunende functies zijn de verschillen beperkt. Bij deze functies bedraagt het aantal leerlingen per onderwijsondersteuner circa I3O-I4O. Het aantal leerlingen per technisch instrumentele onderwijsondersteunener is daarentegen wel aanzienlijk hoger. Scholen hebben gemiddeld slechts één technische onderwijsondersteuner op de 222 leerlingen in dienst.

Figuur 4.5 geeft een overzicht van de totaal aantal personeelsleden- onderwijsondersteuner ratio voor de drie soorten onderwijsondersteuners. Voor pedagogisch/verzorgende, pedagogisch/didactische en andere onderwijsondersteunende functies zijn er per onderwijsondersteuner gemiddeld II-I4 personeelsleden in dienst. 


\section{Figuur 4.4}

Gemiddeld aantal leerlingen per onderwijsondersteuner, per soort onderwijsondersteuner

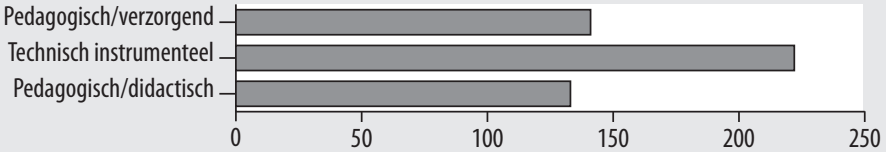

Alleen voor technisch instrumentele onderwijsondersteunende functies (TOA's) is de ratio totaal personeel-onderwijsondersteuner groter: Gemiddeld heeft één op de 22 personeelsleden een onderwijsondersteunende functie.

\section{Figuur 4.5}

Gemiddeld aantal personeelsleden per onderwijsondersteuner, per soort onderwijsondersteuner

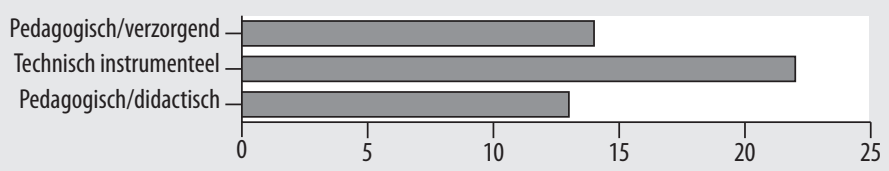

\section{Verblijfsduur in de functie}

Hoe lang zijn verschillende soorten onderwijsondersteuners in dienst? Figuur 4.6 geeft een overzicht van de gemiddelde verblijfsduur in de huidige functie. Onderwijsondersteuners met pedagogisch/verzorgende functies zijn gemiddeld genomen het minst lang werkzaam in de huidige functie. Circa $70 \%$ van deze ondersteuners hebben hun huidige functie minder dan 6 jaar. Ondersteuners met een technisch instrumentele functie zijn gemiddeld genomen wat langer werkzaam in hun huidige functie. Circa $45 \%$ heeft de huidige functie meer dan 6 jaar. Daarnaast valt op dat een aanzienlijk gedeelte (3I\%) van de ondersteuners met technisch instrumentele functies de huidige functie al meer dan II jaar vervult. Voor ondersteuners met pedagogisch/didactische functies is het beeld net iets anders. De helft van de ondersteuners met deze functies heeft de huidige baan minder dan 6 jaar, terwijl ruim $40 \%$ de huidige functie al 6-Io jaar vervult. Een kleine minderheid heeft de huidige functie al meer dan 2I jaar. 


\section{Figuur 4.6}

Gemiddelde verblijfsduur in de huidige functie van onderwijsondersteuners, per soort onderwijsondersteuner, in \%

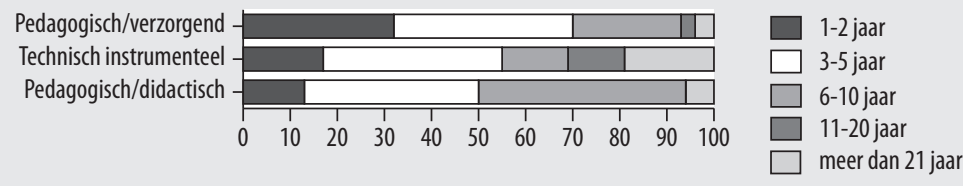

\section{Vakken waarbij onderwijsondersteuners betrokken zijn}

Bij welke vakken zijn onderwijsondersteuners betrokken? Figuur 4.7 geeft voor de verschillende soorten onderwijsondersteuners een overzicht van de vakken waarbij ze betrokken zijn. Het blijkt dat onderwijsondersteuners met pedagogisch/verzorgende en pedagogisch/didactische functies vooral betrokken zijn bij rekenen, lezen en schrijven. Vooral bij het lezen zijn veel onderwijsondersteuners met deze functies betrokken: ruim de helft van hen assisteert bij het vak lezen.

\section{Figuur 4.7}

Vakken waarbij onderwijsondersteuners zijn betrokken, per soort onderwijsondersteuner, in \%

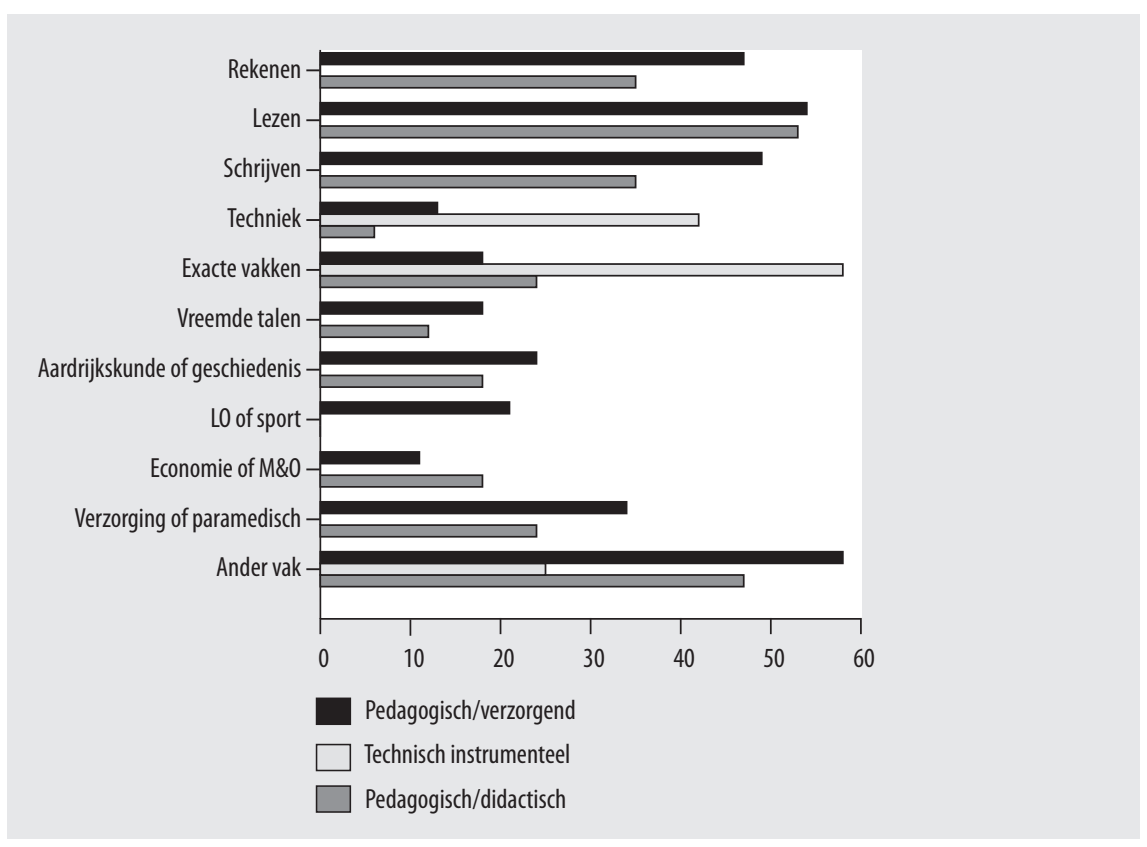

Ondersteuners met technisch instrumentele zijn daarentegen vooral betrokken bij techniek en de exacte vakken (wiskunde, natuurkunde, scheikunde of biologie). Ook blijkt dat onderwijsondersteuners in het algemeen relatief weinig betrokken zijn bij 
het onderwijs in vreemde talen, aardrijkskunde of geschiedenis, lichamelijke opvoeding (LO) of sport en economie of management en organisatie (M\&O). Bij verzorgende of paramedische vakken is circa een derde van de onderwijsondersteuners met pedagogisch/verzorgende functies betrokken. Het is opmerkelijk dat circa de helft van de onderwijsondersteuners met pedagogisch/verzorgende en pedagogisch/didactische functies betrokken is bij 'andere vakken'. In de praktijk gaat het hierbij bijvoorbeeld om maatschappijleer, cultureel-expressieve vakken (tekenen, handvaardigheid) en ICT-vakken.

Bij hoeveel verschillende vakken zijn onderwijsondersteuners in hun werk betrokken? Figuur 4.8 geeft een overzicht van het aantal vakken waarbij onderwijsondersteuners met verschillende soorten functies assisteren.

Figuur 4.8

Aantal vakken waarbij onderwijsondersteuners assisteren, per soort onderwijsondersteuner, in \%

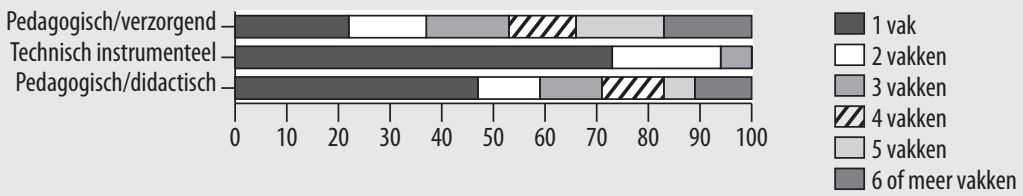

Op dit punt blijken er aanzienlijke verschillen te zijn tussen de verschillende onderwijsondersteunende functies. Zo blijkt ruim $70 \%$ van de onderwijsondersteuners met technisch instrumentele functies betrokken te zijn bij slechts één vak. Dit heeft waarschijnlijk te maken met de specifieke vakkennis die voor dit soort functies vereist is. Circa de helft van de onderwijsondersteuners met pedagogisch/didactische functies is betrokken bij één vak. Voor ondersteuners met pedagogisch/verzorgende functies is het beeld duidelijk anders. Ondersteuners met dit soort functies zijn vaak bij meerdere vakken betrokken: Ruim $60 \%$ van deze ondersteuners is in het werk zelfs betrokken bij het onderwijs in drie of meer verschillende vakken.

\subsection{Opleidingsachtergrond van onderwijsondersteuners}

Welke opleidingen leiden op tot onderwijsondersteuner? Figuur 4.9 geeft daarvan voor de verschillende onderwijsondersteunende functies een overzicht. De figuur laat zien dat er een grote diversiteit bestaat in de hoogst voltooide opleiding voor onderwijsondersteuners. Dit betekent dat er in het verleden heel wat leerwegen zijn geweest tot onderwijsondersteuner. Ondersteuners met een pedagogisch/verzorgende onderwijsondersteunende functie hebben meestal een opleiding op MBO-niveau gevolgd, maar bij minder dan één op de drie onderwijsondersteuners gaat het om een opleiding onderwijsassistent of MBO sociaal pedagogisch werk (SPW). Opvallend is dat heel wat werkzame ondersteuners met een pedagogisch/verzorgende functie een andere 
MBO opleiding gevolgd hebben. Uit achterliggende gegevens blijkt dat het hier vaak gaat om een technische $\mathrm{MBO}$ opleiding. Ruim 30\% van de onderwijsondersteuners met pedagogisch/verzorgende functies heeft een algemeen vormende of een opleiding onder het $\mathrm{MBO}$ niveau gevolgd. Het gaat hier vooral om mensen met een MAVO, HAVO of VMBO opleiding. Het aandeel van ondersteuners met een pedagogisch/ verzorgende functie dat een $\mathrm{HBO}$ opleiding gevolgd heeft bedraagt slechts $12 \%$.

Voor ondersteuners met een technisch instrumentele functie is het beeld anders. Slechts IO\% heeft een opleiding tot technisch onderwijsondersteuner (TOA) gevolgd Meer dan $40 \%$ heeft een andere opleiding op MBO-niveau gevolgd. Daarbij gaat het meestal om een technische MBO opleiding. IO\% heeft een opleiding MBO onderwijsassistent en $4 \%$ heeft de opleiding MBO SPW afgerond. Evenals bij de pedagogisch/verzorgende functies zijn er weinig technisch onderwijsondersteuners met een afgeronde $\mathrm{HBO}$-opleiding. $20 \%$ van de technisch onderwijsondersteuners heeft een 'andere' opleiding gevolgd. Een gedeelte van deze ondersteuners heeft een opleiding onder MBO-niveau afgerond. Voor opleidingsondersteuners met een pedagogisch/ didactische opleiding is het beeld duidelijk anders. Circa de helft van deze ondersteuners heeft een $\mathrm{HBO}$-opleiding gevolgd. Het gaat dan vooral om afgestudeerden van de $\mathrm{PABO}$ en het $\mathrm{HBO}$ culturele en maatschappelijke vorming (CMV). Ongeveer één op de vijf ondersteuners met een pedagogisch/didactische functie heeft de opleiding MBO onderwijsassistent gevolgd, terwijl $25 \%$ van hen een andere opleiding op MBOniveau heeft afgerond.

\section{Figuur 4.9}

Hoogst voltooide opleiding van onderwijsondersteuners, per soort onderwijsondersteuner, in \%

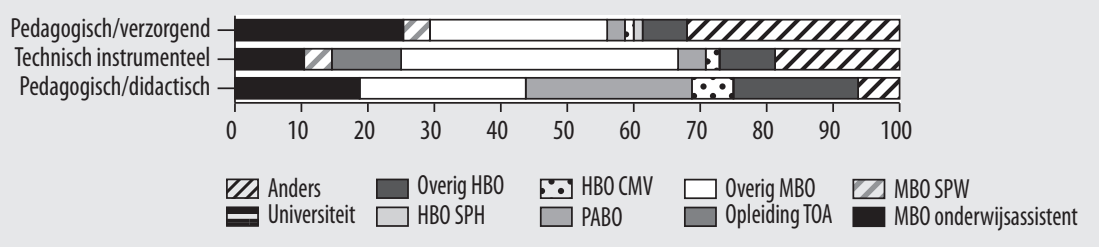

In hoeverre sluit de functie die onderwijsondersteuners hebben aan bij de opleiding die ze gevolgd hebben? Figuur 4.IO geeft daarvan een overzicht voor de verschillende onderwijsondersteunende functies. Het blijkt dat de meerderheid van de onderwijsondersteuners vindt dat de huidige functie voldoende of zelfs goed aansluit bij de door hen gevolgde opleiding. Toch zijn er ook enkele opmerkelijke verschillen tussen de verschillende soorten functies. Zo blijkt dat ondersteuners met een pedagogisch/didactische functie de aansluiting tussen hun functie en opleiding wat minder goed vinden dan de onderwijsondersteuners met andere functies: bijna 40\% vindt de aansluiting tussen functie en opleiding matig of onvoldoende. 


\section{Figuur 4.10}

Aansluiting tussen opleiding en huidige functie, per soort onderwijsondersteuner, in \%

Pedagogisch/verzorgend Technisch instrumenteel Pedagogisch/didactisch

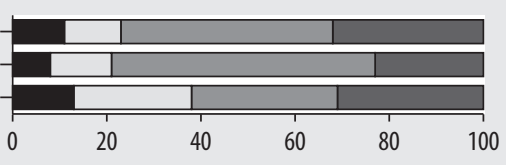

Goed

Voldoende

Matig

Onvoldoende

\subsection{Benutting van capaciteiten, kennistekorten en bruikbaarheid van kennis}

In welke mate vinden onderwijsondersteuners met verschillende functies dat hun capaciteiten voldoende benut worden? Figuur 4.II laat duidelijk zien dat de ondersteuners hier positief over oordelen. Zo vindt $70-80 \%$ van de onderwijsondersteuners dat hun capaciteiten grotendeels of volledig benut worden. Ondersteuners met pedagogisch/verzorgende functies zijn op dit vlak het meest positief. Van hen vindt ruim $30 \%$ dat hun capaciteiten volledig benut worden in hun huidige functie. Technisch onderwijsondersteuners zijn ook overwegend positief. Slechts $2 \%$ van de ondersteuners met technisch instrumentele functies vindt dat de huidige functie helemaal niet aansluit bij de gevolgde opleiding.

\section{Figuur 4.11}

Benutting van capaciteiten per soort onderwijsondersteuner, in \%

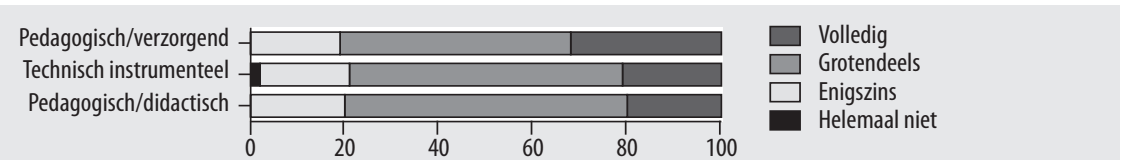

Naast onderbenutting van kennis en vaardigheden kan er natuurlijk ook sprake zijn van kennistekorten bij onderwijsondersteuners. Figuur 4.I2 geeft daarvan een overzicht. In de vraag die aan de onderwijsondersteuners gesteld is was er ook een mogelijkheid om aan te kruisen dat men veel kennis miste. Opmerkelijk is dat geen enkele onderwijsondersteuners deze antwoordcategorie heeft gekozen. Wanneer er wel sprake is van kennistekorten dan gaat het -naar eigen zeggen-slechts om enige kennis die de ondersteuners missen.

\section{Figuur 4.12}

Kennistekorten per soort onderwijsondersteuner, in \%

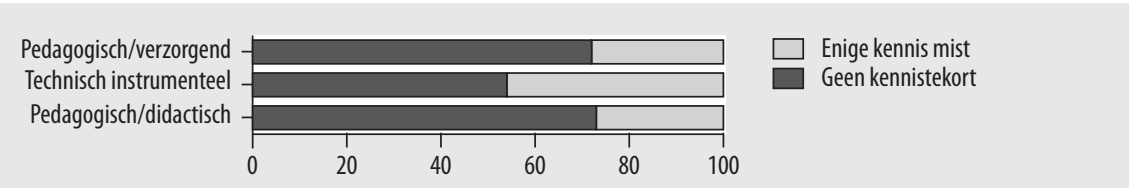


Voor iedere functiecategorie geldt dat de meerderheid van de ondersteuners vindt dat er geen kennis mist, maar er zijn tussen de verschillende soorten onderwijsondersteuners wel enkele kleine verschillen. Ondersteuners met pedagogisch/verzorgende en pedagogisch/didactische functies oordelen het meest positief. Ruim $70 \%$ van deze onderwijsondersteuners vindt dat ze in hun functie niet geconfronteerd worden met kennistekorten. Ondersteuners met technisch instrumentele functies zijn duidelijk minder positief. Bijna de helft van de technisch onderwijsondersteuners vindt dat ze enige kennis missen om de huidige functie goed te kunnen vervullen. Dit hangt waarschijnlijk samen met de vakinhoudelijke kennis die nodig is voor de functie. Doordat deze kennis waarschijnlijk in grote mate technisch van aard is, en dus sterker onderhevig is aan kennisveroudering door technologische innovaties, ervaren technisch onderwijsondersteuners vaker dat een deel van hun kennis tekortschiet dan ondersteuners waarvoor het werk in grote mate pedagogisch van aard is.

Wanneer de functie aansluit bij de kennis en vaardigheden waarover iemand beschikt en de capaciteiten van onderwijsondersteuners worden benut, dan zegt dat nog niets over de bruikbaarheid van de kennis en vaardigheden buiten de huidige baan. In hoeverre zijn de kennis en vaardigheden van onderwijsondersteuners specifiek (alleen bruikbaar binnen de eigen school) of generiek (ook bruikbaar buiten de eigen school)? Figuur 4.I3 geeft daarvan een overzicht. Het algemene beeld is dat een meerderheid van de onderwijsondersteuners vindt dat de kennis en vaardigheden die ze hebben ook volledig of goed bruikbaar zouden zijn in een onderwijsondersteunende functie buiten de school waar ze werken. Bij ondersteuners met pedagogisch/verzorgende functies vindt bijna $80 \%$ dat de kennis en vaardigheden ook elders volledig of goed bruikbaar zouden zijn. Het aandeel van ondersteuners met deze functies dat negatief oordeelt en de bruikbaarheid als beperkt of zelfs helemaal niet bruikbaar bestempelt is met $7 \%$ klein.

\section{Figuur 4.13}

Bruikbaarheid van kennis en vaardigheden in een onderwijsondersteunende functie buiten de huidige school, per soort onderwijsondersteuner, in \%
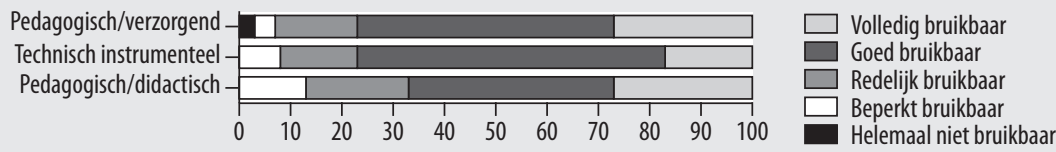

Ook ondersteuners met technisch instrumentele functies zijn overwegend positief over de mate waarin hun kennis en vaardigheden ook elders benut zouden kunnen worden. Wel vinden technisch onderwijsondersteuners wat minder vaak dat de kennis en vaardigheden elders volledig bruikbaar zijn dan onderwijsondersteuners met pedagogisch/verzorgende of pedagogisch/didactische functies. 


\subsection{Conclusies}

De gepresenteerde analyses in dit hoofdstuk hebben duidelijk gemaakt dat de rol en de positie van onderwijsondersteuners sterk afhangt van de context waarin ze werkzaam zijn. Daarbij zijn zowel de onderwijssector als het soort functie waarin men werkzaam is van belang. Onderwijsondersteuners met pedagogisch/verzorgende functies werken in verschillende onderwijssectoren maar komen vooral voor in het (speciaal) primair onderwijs. Pedagogisch/didactische functies komen voor in zowel het primair als in het voortgezet onderwijs maar spelen de grootste rol in de BVE. Onderwijsondersteuners met technisch instrumentele functies werken daarentegen met name in het voortgezet onderwijs en in mindere mate in het speciaal voortgezet onderwijs en de BVE.

Tussen de verschillende onderwijssectoren en de soorten onderwijsondersteunende functies bestaan er opmerkelijke verschillen in de positie van onderwijsondersteuners binnen de school waarin ze werkzaam zijn. Binnen het speciaal onderwijs spelen onderwijsondersteuners een meer prominente rol. In deze sector is het aantal leerlingen per onderwijsondersteuner veel kleiner dan in de andere onderwijssectoren. Ook is de verhouding tussen het totale personeelsbestand en het aantal onderwijsondersteuners in het speciaal onderwijs kleiner dan in het gewone onderwijs. Ook tussen de verschillende soorten onderwijsondersteuners zijn er verschillen in de verhouding tussen het aantal onderwijsondersteuners en het aantal leerlingen en personeelsleden. Het blijkt dat zowel het aantal leerlingen als het aantal personeelsleden per onderwijsondersteuner voor ondersteuners met technisch instrumentele functies groter is dan voor andere onderwijsondersteunende functies. Er zijn ook verschillen tussen onderwijsondersteuners wat betreft de verblijfsduur in de huidige functie. Ondersteuners met pedagogisch/verzorgende functies zijn gemiddeld genomen het minst lang werkzaam in hun huidige functie. Technisch onderwijsondersteuners zijn daarentegen gemiddeld wat langer werkzaam in hun huidige functie.

Er bestaat een behoorlijke variatie in de opleidingsachtergrond van de opleidingsondersteuners die momenteel aan het werk zijn in het Nederlandse onderwijs. Ondersteuners met pedagogisch/verzorgende hebben meestal een opleiding op MBO-niveau gevolgd, maar bij minder dan één op de drie gaat het om een opleiding onderwijsassistent of MBO SPW. Van de technisch onderwijsondersteuners heeft slechts IO\% een opleiding TOA gevolgd. Voor opleidingsondersteuners met een pedagogisch/didactische functie is het beeld duidelijk anders: De helft van deze onderwijsondersteuners heeft een $\mathrm{HBO}$-opleiding gevolgd. In het algemeen vinden onderwijsondersteuners dat de functie die ze hebben goed aansluit bij de gevolgde opleiding. Ondersteuners met een pedagogisch/didactische functie zijn echter wat minder positief over de aansluiting tussen de opleiding en hun functie dan de andere ondersteuners.

Over de benutting van capaciteiten zijn de meeste onderwijsondersteuners erg positief. Slechts een kleine minderheid vindt dat hun capaciteiten onvoldoende worden 
HOOFDSTUK 4

benut. Ook ervaren onderwijsondersteuners geen ernstige kennistekorten. Circa de helft van de ondersteuners met technisch instrumentele functies vindt echter wel dat ze enige kennis missen. Ten slotte blijkt dat een meerderheid van de onderwijsondersteuners vindt dat hun kennis en vaardigheden ook bruikbaar zijn in een onderwijsondersteunende functie buiten de school waar ze nu werkzaam zijn. 


\section{Samenhang tussen kenmerken van onderwijsondersteunende functies}

\section{$5.1 \quad$ Inleiding}

In dit hoofdstuk analyseren we de samenhang tussen de functiekenmerken van de verschillende onderwijsondersteunende functies. Het doel van de analyses is om een beeld te krijgen van de verschillende soorten onderwijsondersteunende functies zonder a priori uit te gaan van de eerder besproken indeling van ondersteunende functies in de categorieën pedagogisch/verzorgend, technisch instrumenteel en pedagogisch/didactisch.

In paragraaf 5.2 wordt er ingegaan op de relatie tussen de taken, de activiteiten en de benodigde competenties in het werk van onderwijsondersteuners. Op basis van correlatie-analyses zal onderzocht worden welke functiekenmerken met elkaar samenhangen. Achtereenvolgens gaan we in op de samenhang tussen de taken en de activiteiten, de taken en de benodigde competenties en de activiteiten en de benodigde competenties. Dit geeft een eerste indruk van de inhoud van verschillende onderwijsondersteunende functies. In paragraaf $5.3 \mathrm{kijken}$ we met behulp van principale componenten analyses óf en in hoeverre de functiekenmerken geclusterd kunnen worden. Op deze wijze kan er een beeld ontstaan van de inhoud van onderwijsondersteunende functies zonder dat daarbij wordt uitgegaan van de eerder besproken driedeling in profielen. Paragraaf 5.4 sluit het hoofdstuk af met de belangrijkste conclusies.

\subsection{Correlaties tussen functiekenmerken}

In hoeverre is er sprake van statistisch significante relaties tussen de diverse kenmerken van onderwijsondersteunende functies? We proberen deze vraag te beantwoorden door te kijken naar de correlaties tussen (I) taken en activiteiten, (2) taken en benodigde competenties en (3) activiteiten en benodigde competenties. Op deze wijze ontstaat er een beeld van de mate waarin verschillende soorten kenmerken van onderwijsondersteunende functies met elkaar samenhangen. 


\section{Taken en activiteiten}

We kijken eerst naar de correlaties tussen de taken van onderwijsondersteuners en de activiteiten die ze in hun werk uitvoeren. De combinatie van I4 taken en 24 activiteiten levert een correlatiematrix op met 336 cellen. Uit de analyse blijkt dat er sprake is van een sterke positieve samenhang tussen de taken in het takenpakket van onderwijsondersteuners en de activiteiten die ze uitvoeren. Van de 336 correlatiecoëfficiënten zijn er 292 significant (op het $5 \%$ niveau). De meeste correlaties liggen tussen 0, 3 en 0,5 en het overgrote deel van deze correlaties is positief. Dit betekent dat deze taken tegelijkertijd voorkomen in de functie. Daarentegen zijn I9 correlaties negatief. Dit duidt op een invers verband. Een negatieve correlatie wil zeggen dat het voorkomen van een bepaalde taak in een functie betekent dat bepaalde activiteiten bij het uitvoeren niet relevant zijn en geen deel uitmaken van de functie. Het is opvallend dat de negatieve correlaties zich vooral manifesteren bij twee taken: practica en experimenten faciliteren en leerlingen bij tijdens practica en experimenten begeleiden.

In tabel 5.I wordt een overzicht gegeven van de taken en activiteiten die positief met elkaar gecorreleerd zijn. Het gaat hier om correlaties met een waarde van minstens 0,4 . De tabel laat zien dat er niet alle taken van onderwijsondersteuners geassocieerd kunnen worden met één of meerdere concrete activiteiten. Het gaat hier om extra-curriculaire activiteiten organiseren, individuele leerlingen buiten het onderwijsproces begeleiden, practica en experimenten faciliteren, leerlingen tijdens practica en experimenten begeleiden, leerlingen bij het inoefenen van beroepsvaardigheden begeleiden en kleine groepen leerlingen buiten het onderwijsproces begeleiden. Deze taken zijn wellicht minder direct gerelateerd aan concrete activiteiten in het werk van onderwijsondersteuners.

Tabel 5.1

Taken en activiteiten van onderwijsondersteuners die sterk positief met elkaar gecorreleerd zijn $(r>0,4)$

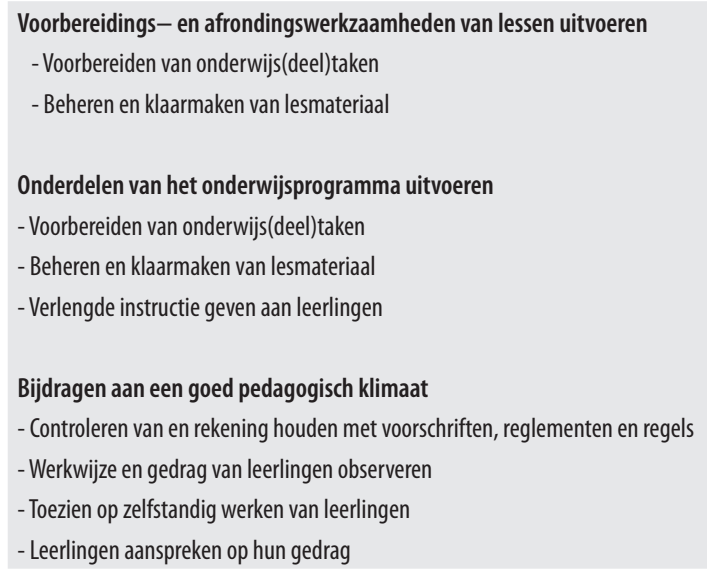




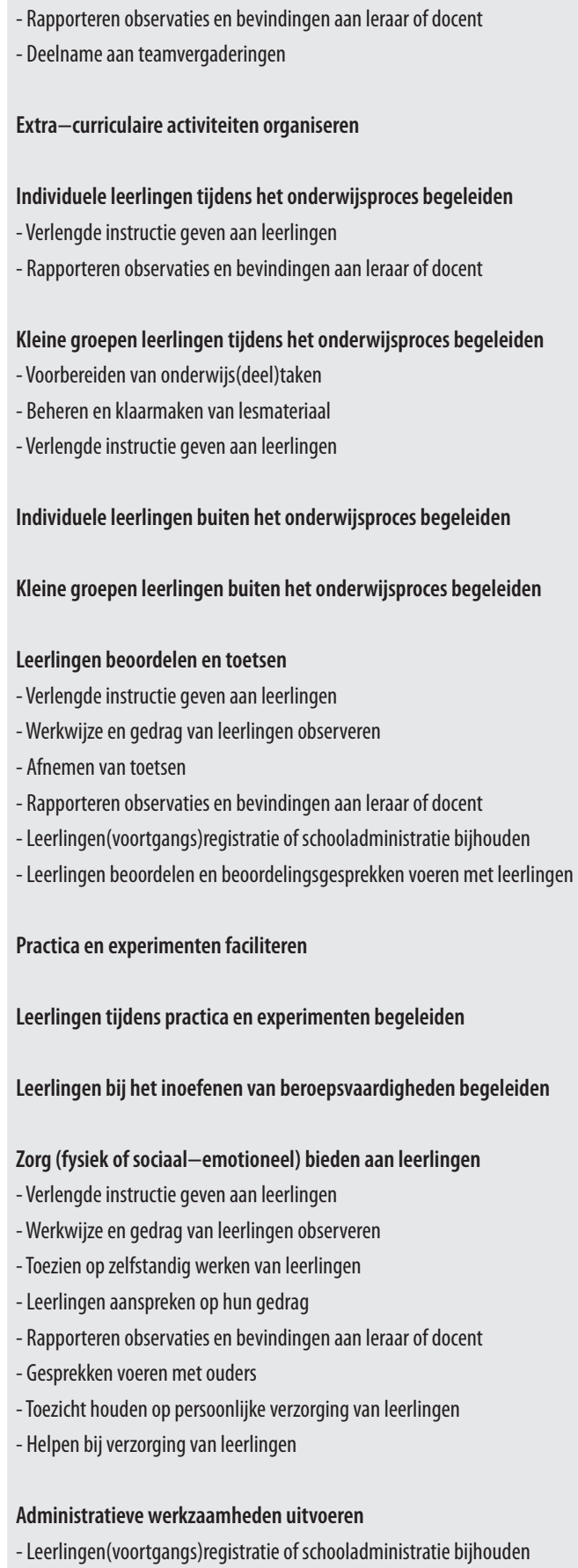


Uit de tabel komt ook naar voren dat een aantal activiteiten in onderwijsondersteunende functies samenhangt met verschillende taken. Wanneer we kijken naar de activiteiten die minstens voor drie taken van belang zijn dan gaat het om de volgende activiteiten: voorbereiden van onderwijs(deel)taken, beheren en klaarmaken van lesmateriaal, verlengde instructie geven aan leerlingen, werkwijze en gedrag van leerlingen observeren, en rapporteren observaties en bevindingen aan leraar of docent.

\section{Taken en benodigde competenties}

De frequentie van het voorkomen van bepaalde taken in het takenpakket van onderwijsondersteuners heeft vanzelfsprekend ook gevolgen voor de benodigde competenties. De relatie tussen de taken en de benodigde competenties wordt ook met behulp van een correlatie-analyse onderzocht. Ook deze analyse levert een correlatiematrix van 336 cellen op ( 14 taken x 24 competenties). I44 correlaties zijn significant. Hiervan zijn er I27 positief en I7 negatief. Wel blijkt de sterkte van de correlaties in de meeste gevallen beperkt. De meeste correlaties bedragen slechts 0,I-0,2. Dit betekent dat de samenhang tussen taken en competenties kleiner is dan de samenhang tussen taken en activiteiten: zowel het aantal significante correlaties als de gemiddelde sterkte van de correlaties is kleiner. Om een indruk te geven van de mate waarin de competenties een rol spelen bij de taken in het werk van onderwijsondersteuners geeft figuur 5.I voor alle onderscheiden competenties aan hoeveel taken significant en positief met de desbetreffende competentie samenhangt. Dit aantal is bepaald door te kijken naar alle positieve correlaties met een waarde van minstens O,I.

Uit de figuur blijkt dat een aantal benodigde competenties voor verschillende taken van belang is. Zo blijkt dat het vermogen om verschillende didactische werkvormen toe te passen voor maar liefst II van de I4 verschillende taken benodigd is. Ook het vermogen om ontwikkelingsmogelijkheden van kinderen optimaal te benutten is van groot belang. Voor maar liefst Io taken is deze competentie nodig. Enkele andere competenties die voor meerdere taken van belang zijn, zijn het vermogen om leerlingen de verzorging te geven die ze nodig hebben, het vermogen om leerlingen op verschillende manieren te beoordelen, het vermogen om de behoefte van leerlingen te interpreteren, het vermogen om de eigen pedagogische opvattingen te integreren in het onderwijsleerproces, het vermogen om knopen door te hakken en de kennis van de eindtermen van de eigen onderwijsinstelling. 
Figuur 5.1

Aantal taken waarmee competenties positief gecorreleerd zijn $(r>0,1)$

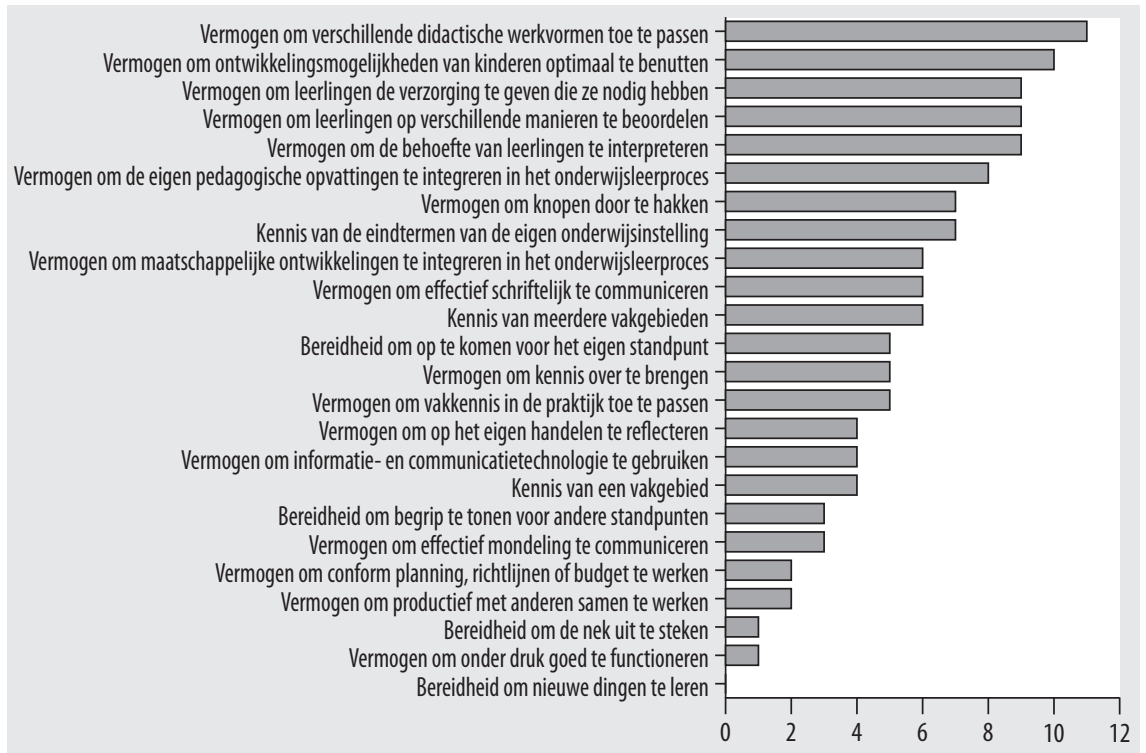

\section{Activiteiten en benodigde competenties}

In hoeverre is er een samenhang tussen bepaalde activiteiten die onderwijsondersteuners verrichten en de voor de functie benodigde competenties? De correlatie-analyse van activiteiten en benodigde competenties levert een correlatiematrix op van 576 cellen op ( 24 activiteiten x 24 competenties). 3IO competenties zijn significant en deze zijn allemaal positief. Om een beeld te krijgen van de competenties die het meest van belang zijn bij het uitvoeren van de activiteiten in het werk van onderwijsondersteuners geeft figuur 5.2 per competentie een overzicht van het aantal activiteiten waarvoor de competentie van belang is.

Ook hier blijkt dat er competenties zijn die bij het uitvoeren van veel verschillende activiteiten noodzakelijk zijn. Drie competenties zijn zelfs in 23 van de 24 onderscheiden activiteiten van belang. Het gaat hier om het vermogen om leerlingen op verschillende manieren te beoordelen, het vermogen om ontwikkelingsmogelijkheden van kinderen optimaal te benutten, en het vermogen om verschillende didactische werkvormen toe te passen. Een aantal andere competenties die vereist zijn voor het uitvoeren van een groot aantal verschillende activiteiten zijn:

- Het vermogen om maatschappelijke ontwikkelingen te integreren in het onderwijsleerproces.

- Het vermogen om de behoefte van leerlingen te interpreteren. 
- Het vermogen om de eigen pedagogische opvattingen te integreren in het onderwijsleerproces.

- Het vermogen om leerlingen de verzorging te geven die ze nodig hebben.

- Het vermogen om effectief schriftelijk te communiceren.

- De kennis van de eindtermen van de eigen onderwijsinstelling.

Figuur 5.2

Aantal activiteiten waarmee competenties positief gecorreleerd zijn $(r>0,1)$

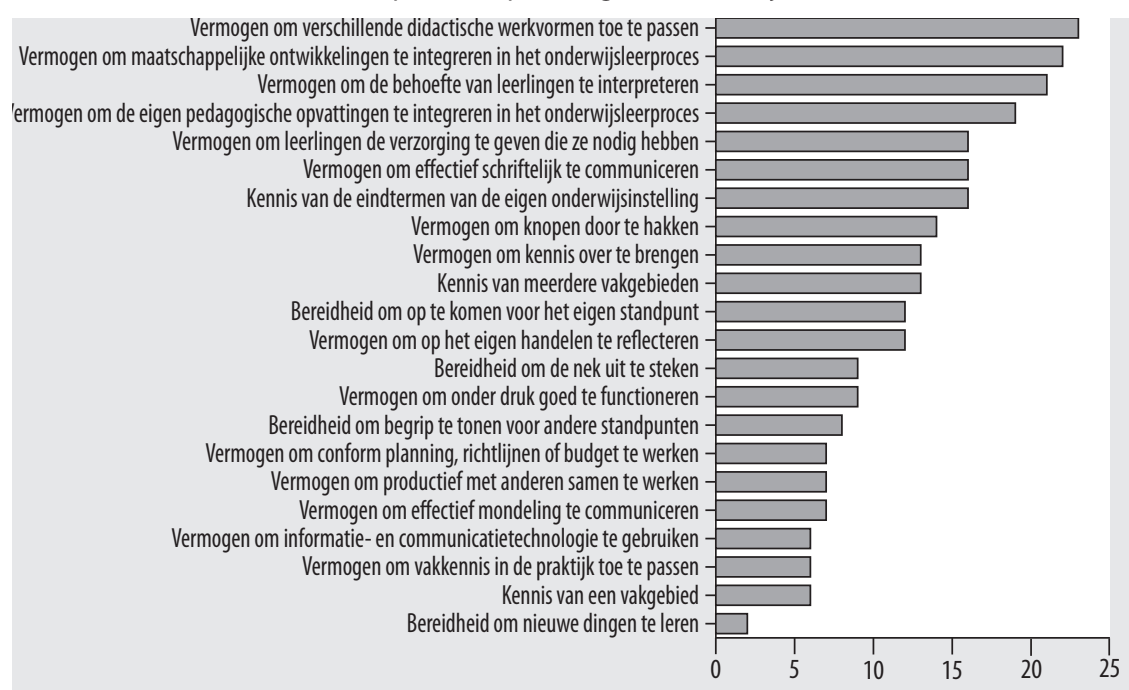

\subsection{Clustering van onderwijsondersteunende functies}

In de voorgaande paragraaf hebben we gekeken naar de mate waarin verschillende taken, activiteiten en competenties met elkaar samenhangen. Het is echter de vraag of het samenspel van deze functiekenmerken duidt op een bepaalde clustering voor onderwijsondersteunde functies. Hierop gaan we in deze paragraaf in. Voor zowel taken, activiteiten als competenties zijn er principale componenten analyses uitgevoerd. In deze analyses wordt geprobeerd een statistische structuur te vinden in de taken, activiteiten en competenties van onderwijsondersteuners. Uit de analyses blijkt dat alleen de componenten analyse met betrekking tot de taken van onderwijsondersteuners leidt tot goed interpreteerbare resultaten. De analyses met betrekking tot activiteiten en competenties leidt tot een groot aantal verschillende clusters die relatief weinig van elkaar verschillen. Dit kan wellicht verklaard worden door het feit dat de grotere mate van detaillering in de activiteiten en competenties van onderwijsondersteuners er toe leidt dat er een groot aantal verschillende functies ontstaat die slechts op details van elkaar verschillen. Omdat we op zoek zijn naar belangrijke verschillen tussen verschillende onderwijsondersteunende functies en vanwege de problematische 
interpretatie van de clusteranalyse van activiteiten en competenties bespreken we hier alleen de componenten analyse die uitgevoerd is voor taken. Het doel van deze analyse is om te onderzoeken in hoeverre het takenpatroon van onderwijsondersteuners met verschillende taken duidt op een bepaalde clustering.

\section{Clustering van taken}

De principale componenten analyse voor taken in onderwijsondersteunende functies wijst op het bestaan van vier componenten, die gezien kunnen worden als indicatief voor vier onderwijsondersteunende functies. Deze vier componenten verklaren tezamen $63,6 \%$ van de totale variantie. In tabel 5.2 geven we een overzicht van de verdeling van de taken over de vier clusters.

Tabel 5.2

Clusters van taken op basis van principale componenten analyse

\begin{tabular}{|c|c|c|c|c|}
\hline \multirow[b]{2}{*}{ Taak } & \multicolumn{4}{|c|}{ Cluster } \\
\hline & 1 & 2 & 3 & 4 \\
\hline Voorbereidings - en afrondingswerkzaamheden van lessen uitvoeren & + & + & - & - \\
\hline Onderdelen van het onderwijsprogramma uitvoeren & + & + & - & - \\
\hline Bijdragen aan een goed pedagogisch klimaat & + & - & - & + \\
\hline Extra-curriculaire activiteiten organiseren & + & + & - & + \\
\hline Individuele leerlingen tijdens het onderwijsproces begeleiden & + & - & + & - \\
\hline Kleine groepen leerlingen tijdens het onderwijsproces begeleiden & + & + & - & - \\
\hline Individuele leerlingen buiten het onderwijsproces begeleiden & + & - & + & - \\
\hline Kleine groepen leerlingen buiten het onderwijsproces begeleiden & + & - & + & - \\
\hline Leerlingen beoordelen en toetsen & + & + & - & + \\
\hline Practica en experimenten faciliteren & - & + & + & - \\
\hline Leerlingen tijdens practica en experimenten begeleiden & - & + & + & - \\
\hline Leerlingen bij het inoefenen van beroepsvaardigheden begeleiden & + & + & - & + \\
\hline Zorg (fysiek of sociaal-emotioneel) bieden aan leerlingen & + & - & + & + \\
\hline Administratieve werkzaamheden uitvoeren & + & + & - & + \\
\hline
\end{tabular}

Noot: + staat voor een positive invloed van de betreffende taak op het cluster, - staat voor een negatieve invloed

De analyse laat dus zien dat de verschillende taken binnen onderwijsondersteunende functies in vier clusters kunnen worden samengevat. Hieronder bespreken we de vier clusters. We gaan daarbij in op zowel de taken als de activiteiten die in de verschillende clusters van belang zijn. De overzichten van de activiteiten die bij de vier clusters horen zijn gebaseerd op de correlatie-analyse uit de vorige paragraaf.

Cluster I: Het gaat hier om een cluster waarvoor I2 taken relevant zijn, terwijl er twee negatieve componenten zijn. Deze negatieve componenten zijn de taken practica en experimenten faciliteren en leerlingen tijdens practica en experimenten begeleiden. Het cluster omvat dus alle taken, behalve de taken die vaak geassocieerd worden met technisch onderwijsondersteuners. Vanwege het groot aantal positieve componenten 
zouden we dit cluster kunnen bestempelen als de brede niet-technisch onderwijsondersteunende functies. Aangezien deze functies een veelheid van verschillende taken omvatten, is er ook sprake van een groot aantal uiteenlopende activiteiten. Het gaat om:

- Voorbereiden van onderwijs(deel)taken.

- Beheren en klaarmaken van lesmateriaal.

- Verlengde instructie geven aan leerlingen.

- Controleren van en rekening houden met voorschriften, reglementen en regels.

- Werkwijze en gedrag van leerlingen observeren.

- Toezien op zelfstandig werken van leerlingen.

- Leerlingen aanspreken op hun gedrag.

- Rapporteren observaties en bevindingen aan leraar of docent.

- Deelname aan teamvergaderingen.

- Afnemen van toetsen.

- Leerlingen(voortgangs)registratie of schooladministratie bijhouden.

- Leerlingen beoordelen en beoordelingsgesprekken voeren met leerlingen.

- Gesprekken voeren met ouders.

- Toezicht houden op persoonlijke verzorging van leerlingen.

- Helpen bij verzorging van leerlingen.

Cluster 2: Dit cluster omvat negen positieve componenten en vijf negatieve componenten. Het omvat de voorbereiding en de uitvoering van lessen, het organiseren van extra-curriculaire activiteiten, het begeleiden van groepen leerlingen tijdens het onderwijsproces, het toetsen en beoordelen van leerlingen, practica en experimenten faciliteren, leerlingen tijdens practica en experimenten begeleiden, het begeleiden van leerlingen bij het inoefenen van beroepsvaardigheden en het uitvoeren van administratieve werkzaamheden. Het gaat hier om een onderwijsondersteunende functie waarin practica en experimenten en het inoefenen van beroepsvaardigheden een rol spelen. Het cluster omvat ook pedagogisch/didactische activiteiten zoals het uitvoeren van lessen en het beoordelen van leerlingen. Op basis hiervan zouden we het cluster kunnen bestempelen als de technisch onderwijsondersteunende functies. Naast de activiteiten die verband houden met practica en experimenten, zijn in deze functies echter ook de volgende pedagogisch/didactische activiteiten van belang:

- Voorbereiden van onderwijs(deel)taken.

- Beheren en klaarmaken van lesmateriaal.

- Verlengde instructie geven aan leerlingen.

- Werkwijze en gedrag van leerlingen observeren.

- Afnemen van toetsen.

- Rapporteren observaties en bevindingen aan leraar of docent.

- Leerlingen(voortgangs)registratie of schooladministratie bijhouden.

- Leerlingen beoordelen en beoordelingsgesprekken voeren met leerlingen. 
Cluster 3: In dit cluster zijn er zes positieve en acht negatieve componenten. Het begeleiden van en zorg bieden aan leerlingen speelt een belangrijke rol, maar er is geen sprake van het uitvoeren van lessen, het beoordelen en toetsen van leerlingen en het uitvoeren van administratieve werkzaamheden. Practica en experimenten spelen daarentegen wel een rol in dit cluster. Het gaat hier dus om onderwijsondersteunende functies waarin het begeleiden van leerlingen centraal staat, maar waar er ook sprake is van practica en experimenten. We zouden daarom kunnen spreken van technisch begeleiders. Naast activiteiten die specifiek gericht zijn op practica en experimenten zijn de volgende activiteiten van belang:

- Verlengde instructie geven aan leerlingen.

- Rapporteren observaties en bevindingen aan leraar of docent.

- Werkwijze en gedrag van leerlingen observeren.

- Toezien op zelfstandig werken van leerlingen.

- Leerlingen aanspreken op hun gedrag.

- Gesprekken voeren met ouders.

- Toezicht houden op persoonlijke verzorging van leerlingen.

- Helpen bij verzorging van leerlingen.

Cluster 4: In cluster 4 zijn er zes positieve en acht negatieve componenten. De positieve componenten zijn bijdragen aan een goed pedagogisch klimaat, extra-curriculaire activiteiten organiseren, leerlingen beoordelen en toetsen, leerlingen bij het inoefenen van beroepsvaardigheden begeleiden, administratieve werkzaamheden uitvoeren en zorg (fysiek of sociaal-emotioneel) bieden aan leerlingen. Opvallend in dit cluster is dat alle taken die gericht zijn op het begeleiden van individuele leerlingen of groepen leerlingen of lessen uitvoeren of voorbereiden negatieve componenten zijn. Dit betekent dat het cluster onderwijsondersteunende functies aanduidt die wat verder afstaan van het onderwijsleerproces dan de andere clusters. We zouden daarom kunnen spreken van assistenten. In deze functies spelen de volgende activiteiten een belangrijke rol:

- Controleren van en rekening houden met voorschriften, reglementen en regels.

- Werkwijze en gedrag van leerlingen observeren.

- Toezien op zelfstandig werken van leerlingen.

- Leerlingen aanspreken op hun gedrag.

- Rapporteren observaties en bevindingen aan leraar of docent.

- Deelname aan teamvergaderingen.

- Verlengde instructie geven aan leerlingen.

- Werkwijze en gedrag van leerlingen observeren.

- Afnemen van toetsen.

- Rapporteren observaties en bevindingen aan leraar of docent.

- Leerlingen beoordelen en beoordelingsgesprekken voeren met leerlingen.

- Gesprekken voeren met ouders.

- Toezicht houden op persoonlijke verzorging van leerlingen. 
- Helpen bij verzorging van leerlingen.

- Leerlingen(voortgangs)registratie of schooladministratie bijhouden.

\section{Verschillen tussen onderwijssectoren, loopbaanduur en opleidingsachtergrond}

Hoe is de verdeling van de vier onderscheiden clusters van onderwijsondersteunende functies over de verschillende sectoren van het onderwijs? In figuur 5.3 geven we daarvan een overzicht. Van de onderwijsondersteuners die werkzaam zijn in de brede niet-technisch onderwijsondersteunende functies (cluster I) werkt ruim $40 \%$ in de sector primair onderwijs. Ongeveer een kwart van deze ondersteuners werkt in het voortgezet onderwijs, terwijl $20 \%$ in het speciaal primair onderwijs werkzaam is. Voor de technisch onderwijsondersteunende functies (cluster 2) is het beeld duidelijk anders. Ondersteuners met dergelijke functies werken bijna allemaal in het voortgezet of in het speciaal voortgezet onderwijs. Van de technisch begeleiders (cluster 3) werkt ongeveer de helft in het voortgezet onderwijs, terwijl 35\% werkzaam is in het primair onderwijs. Circa IO\% van de ondersteuners met deze functies werkt in de BVE-sector. Assistenten (cluster 4) zijn vooral werkzaam in het voortgezet onderwijs (6I\%), maar ook in het primair onderwijs ( $15 \%$ ) en in het speciaal voortgezet onderwijs (I6\%).

\section{Figuur 5.3}

Verdeling van onderwijsondersteunende functies over de verschillende onderwijssectoren

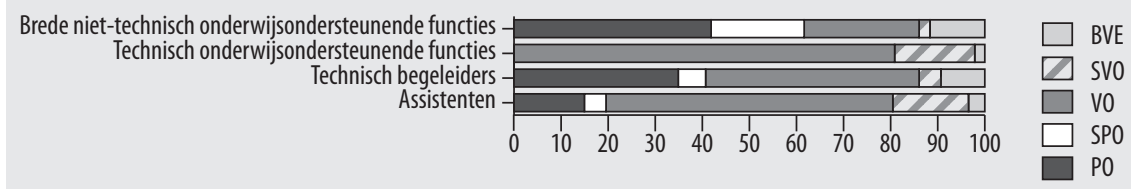

Er is ook gekeken of er tussen de vier onderscheiden groepen van onderwijsondersteuners verschillen zijn in de gemiddelde tijd dat men al werkzaam is of opleidingsachtergrond. Die verschillen zijn in het algemeen klein. Toch zijn er enkele opmerkelijke uitkomsten. Zo blijkt dat de onderwijsondersteuners die werkzaam zijn in technisch onderwijsondersteunende functies (cluster 2) gemiddeld langer in hun huidige functie werkzaam zijn dan assistenten (cluster 4): bijna de helft van de ondersteuners die werkzaam zijn in technisch onderwijsondersteunende functies is al meer dan 5 jaar werkzaam in dezelfde functie, terwijl van de assistenten slechts $23 \%$ meer dan 5 jaar werkzaam is in de huidige functie. Ook zijn er weinig verschillen in de opleidingsachtergrond van de vier onderscheiden onderwijsondersteunende functies. Wel valt het op dat ondersteuners die werkzaam zijn in brede niet-technisch onderwijsondersteunende functies wat vaker een opleiding onderwijsassistent of SPW op MBO niveau hebben gevolgd dan onderwijsondersteuners in de overige drie clusters. Bij de assistenten is het aantal ondersteuners dat geen opleiding op middelbaar of hoger niveau heeft gevolgd groter dan bij de andere clusters. 


\subsection{Conclusies}

In dit hoofdstuk zijn twee soorten analyses gepresenteerd en besproken: correlatieanalyses tussen de taken, activiteiten en vereiste competenties en een principale componenten analyse op basis van de taken van onderwijsondersteuners. Het blijkt dat niet alle taken van onderwijsondersteuners geassocieerd kunnen worden met één of meerdere concrete activiteiten. Het gaat hier om extra-curriculaire activiteiten organiseren, individuele leerlingen buiten het onderwijsproces begeleiden, practica en experimenten faciliteren, leerlingen tijdens practica en experimenten begeleiden, leerlingen bij het inoefenen van beroepsvaardigheden begeleiden en kleine groepen leerlingen buiten het onderwijsproces begeleiden. Deze taken zijn wellicht minder direct verbonden met concrete activiteiten in het werk van onderwijsondersteuners.

De correlatie-analyse tussen de taken en activiteiten laat ook zien dat er activiteiten zijn die samenhangen met verschillende taken in onderwijsondersteunende functies. Activiteiten die voor minstens drie taken van belang zijn, zijn: het voorbereiden van onderwijs(deel)taken, het beheren en klaarmaken van lesmateriaal, het verlengde instructie geven aan leerlingen, de werkwijze en het gedrag van leerlingen observeren, en het rapporteren van observaties en bevindingen aan de leraar of docent.

Uit de correlatie-analyses tussen de taken en vereiste competenties en tussen de activiteiten en de vereiste competenties blijkt dat een aantal vereiste competenties van belang is voor meerdere taken en activiteiten. Het gaat om de volgende competenties:

- Het vermogen om verschillende didactische werkvormen toe te passen.

- Het vermogen om ontwikkelingsmogelijkheden van kinderen optimaal te benutten.

- Het vermogen om leerlingen de verzorging te geven die ze nodig hebben.

- Het vermogen om leerlingen op verschillende manieren te beoordelen.

- Het vermogen om de behoefte van leerlingen te interpreteren.

- Het vermogen om de eigen pedagogische opvattingen te integreren in het onderwijsleerproces.

- De kennis van de eindtermen van de eigen onderwijsinstelling.

In het tweede gedeelte van het hoofdstuk is er een principale-componenten analyse uitgevoerd op basis van de taken die onderwijsondersteuners uitvoeren. Uit deze analyse komt naar voren dat, wanneer we uitgaan van de taken van onderwijsondersteuners, er sprake is van vier clusters, die duiden op het bestaan van vier verschillende onderwijsondersteunende functies. Het gaat achtereenvolgens om:

- Brede niet-technisch onderwijsondersteunende functies: In deze functies zijn de meeste taken van belang, maar spelen experimenten en practica geen rol. 
- Technisch onderwijsondersteunende functies: In deze functies zijn de meeste taken van belang. Kenmerk van deze functies is dat ze zowel pedagogisch/didactische elementen bevat als ook practica, experimenten en beroepsvaardigheden.

- Technisch begeleiders: In deze functies staat het begeleiden van en zorg bieden aan leerlingen centraal, maar er is geen sprake van een directe rol in het uitvoeren van lessen, het beoordelen en toetsen en het uitvoeren van administratieve werkzaamheden. Wel is er sprake van practica en experimenten.

- Assistenten: Diegenen die werkzaam zijn in deze functies spelen geen directe rol in het onderwijsleerproces of bij de begeleiding van individuele of groepen leerlingen. Het gaat in deze functies om het bijdragen aan het pedagogisch klimaat, het organiseren van extra-curriculaire activiteiten, leerlingen beoordelen en toetsen, het inoefenen van beroepsvaardigheden, administreren en zorg bieden aan leerlingen.

Er zijn ook belangrijke verschillen tussen de vier onderscheiden clusters wat betreft hun inzet in de verschillende onderwijssectoren. Zo werken de meeste ondersteuners die werkzaam zijn in de brede niet-technisch ondersteunende functies (cluster I) in het primair onderwijs. Daarnaast worden ze ingezet in het speciaal primair onderwijs en in het voortgezet onderwijs. Onderwijsondersteuners met technisch onderwijsondersteunende functies (cluster 2) werken bijna allemaal in het voorgezet onderwijs of in het speciaal voortgezet onderwijs. Technisch begeleiders (cluster 3) worden daarentegen zowel in het voortgezet onderwijs als in het basisonderwijs ingezet. Assistenten (cluster 4) worden voor het grootste gedeelte in het speciaal onderwijs ingezet, maar ook in het primair en het speciaal voortgezet onderwijs. Ten slotte blijkt dat ondersteuners die werkzaam zijn in technisch onderwijsondersteunende functies (cluster 2) meestal langer in hun huidige functie werkzaam zijn dan ondersteuners in de andere drie clusters en dat assistenten vaker een lagere opleiding hebben gevolgd dan andere onderwijsondersteuners. 


\section{Samenvatting en conclusies}

\subsection{Inleiding}

Onder invloed van verschillende maatschappelijke ontwikkelingen is het aantal ondersteuners in het Nederlandse onderwijs de afgelopen jaren behoorlijk toegenomen. Onderwijsondersteunende functies hebben een groot aantal verschillende benamingen en omdat ze recentelijk zijn ontstaan is er nog geen sprake van een uitgekristalliseerd beroep. Dat werpt de vraag op wat de verschillende onderwijsondersteunende functies inhouden en waar de verschillen en overeenkomsten liggen. Op deze kernvraag zijn we in deze rapportage ingegaan. Achtereenvolgens zijn de volgende elementen aan de orde gekomen:

I. Een ordeningskader voor onderwijsondersteunende functies (hoofdstuk 2).

2. Een analyse van de functiekenmerken van verschillende soorten onderwijsondersteuners (hoofdstuk 3).

3. Een analyse van de positie van onderwijsondersteuners in het Nederlandse onderwijs (hoofdstuk 4).

4. Een analyse van de mate waarin bepaalde functiekenmerken met elkaar samenhangen en een mogelijke clustering van functiekenmerken (hoofdstuk 5).

In dit afsluitende hoofdstuk presenteren we in paragraaf 6.2 - 6.5 stapsgewijs de resultaten uit de afzonderlijke hoofdstukken. In paragraaf 6.6 bespreken we de belangrijkste conclusies.

\subsection{Ordeningskader}

Op basis van een verkennende studie naar onderwijsondersteunende beroepen is geconcludeerd dat de functies ter ondersteuning van het primaire proces in het onderwijs behoren tot één onderwijsondersteunend beroep. Binnen dit beroep zijn er drie verschillende profielen te onderscheiden die, voortkomend uit de aard van de werkzaamheden, ieder een andere oriëntatie hebben. Deze drie profielen zijn:

I. Pedagogisch/verzorgend.

2. Technisch instrumenteel. 


\section{Pedagogisch/didactisch.}

Welke onderwijsondersteunende functies vallen binnen deze profielen en wat zijn de belangrijkste verschillen en overeenkomsten tussen deze drie soorten onderwijsondersteunende functies?

Pedagogisch/verzorgende onderwijsondersteunende functies: Het gaat hier om de functies onderwijsassistent en klassenassistent. In deze functies staat het begeleiden van individuele leerlingen en groepen leerlingen centraal. Bij onderwijsassistenten ligt de nadruk op het onderwijsproces en het uitvoeren van onderdelen van het onderwijsprogramma, inclusief de voorbereidings- en afrondingswerkzaamheden. Voor de klassenassistent die is opgeleid op niveau 3 gaat het met name om het ondersteunen bij de lichamelijke verzorging en het ondersteunen van de leerling tijdens het volgen van de lessen. Klassenassistenten opgeleid op niveau 4 voeren daarnaast eenvoudige routinematige onderwijsinhoudelijke taken uit, begeleiden leerlingen bij het verwerven van vaardigheden en leveren een praktische bijdrage aan het klassenmanagement. Een vergelijking tussen de kernopgaven en beroepscompetenties van beide functies is niet mogelijk, aangezien deze informatie voor klassenassistenten niet beschikbaar is.

Technisch instrumentele onderwijsondersteunende functies: Het gaat hier om technisch onderwijsassistenten (TOA's). Het werk van een TOA heeft twee kerntaken: (I) het faciliteren van practica en vakoverstijgende vaardigheden en (2) het begeleiden van leerlingen tijdens practica en vakoverstijgende werkzaamheden. De TOA heeft te maken met vier kernopgaven: (I) tijd versus kwaliteit, (2) omgaan met leerlingen en samenwerken met de docent, (3) planning versus flexibiliteit en (4) inzicht tonen. Het beroepscompetentieprofiel van de TOA wijkt duidelijk af van het profiel van de onderwijsassistent. Voor onderwijsassistenten zijn de zowel de kerntaken als de kernopgaven meer toegespitst op de pedagogische aspecten van het leerproces. Ook de benodigde beroepscompetenties zijn anders. Voor een TOA zijn de benodigde competenties voor het merendeel technisch van aard. Onderwijsondersteuners met pedagogisch/verzorgende functies moeten vooral beschikken over pedagogische/ didactische en communicatieve competenties.

Pedagogisch/didactische onderwijsondersteunende functies : Het gaat hier om leraarondersteuners, instructeurs, tutoren en begeleiders. Voor de eerste drie functies zijn er functieomschrijvingen beschikbaar. Voor instructeurs en tutoren zijn deze echter relatief contextspecifiek (geldend voor een specifieke school). Voor begeleiders is er helaas geen functieomschrijving beschikbaar. Leraarondersteuners in het primair onderwijs voeren lesondersteunende en leerlingenbegeleidende taken uit onder verantwoordelijkheid van een leraar, ondersteunen de onderwijsvoorbereiding, dragen bij aan de schoolorganisatie en stellen zich actief op in het ontwikkelen van competenties. Verder moeten ze functioneel verantwoordelijkheid afleggen aan de leraar en handelen naar hun aanwijzingen. Tijdens de les wordt er voor leraarondersteuners echter ook een zelfstandige beslisvaardigheid verwacht. 
De voor de functie benodigde kennis en vaardigheden zijn didactische en pedagogische kennis, vakinhoudelijke kennis, organisatorische en sociale vaardigheden en de vaardigheid om kennis en vaardigheden over te dragen. Bij instructeurs ligt de nadruk op het geven van praktijkonderwijs en het daarbij begeleiden van leerlingen. Opmerkelijk is dat ook het bijdragen aan de ontwikkeling en vernieuwing van het praktijkonderwijs als resultaatgebied genoemd wordt. Deze innovatiegerichtheid weerspiegelt zich ook in de benodigde kennis en vaardigheden: Zowel het kunnen toepassen van nieuwe technologieën als het goed kunnen leren van nieuwe vaardigheden zijn een vereiste voor de functie. Voor tutoren ligt de nadruk in de werkzaamheden op het begeleiden van individuele leerlingen of kleine groepen en het doorgeven van informatie aan leerlingen en leraren. Hiervoor is praktische kennis van zowel individuele als groepsbegeleidingsmethoden vereist. Ook een gedegen kennis van nieuwe technologieën is een vereiste. Tutoren moeten bovendien vaardig zijn in het inventariseren van de behoeften van leerlingen, leerlingen kunnen motiveren en studieplannen kunnen opstellen.

De analyse van de verschillende beroepscompetentieprofielen en functieomschrijvingen maakt duidelijk dat het erg moeilijk is om vanuit theoretisch oogpunt vergelijkingen te maken tussen de verschillende ondersteunende beroepen in het onderwijs. Er zijn drie problemen die de vergelijking moeilijk maken:

- Allereerst zijn er grote verschillen in de opzet van de verschillende informatiebronnen. Sommige bronnen spreken van kerntaken en beroepscompetenties; andere hebben het over resultaatgebieden of werkzaamheden en gaan in op de voor de functie benodigde kennis en vaardigheden.

- Daarnaast is er in een aantal informatiebronnen sprake van een contextspecifieke benadering. Terwijl de beroepscompetentieprofielen voor technisch onderwijsassistenten (TOA's) en met name onderwijsassistenten relatief breed zijn opgesteld, hebben de bronnen voor andere onderwijsondersteunende functies betrekking op één specifieke onderwijssector (bijvoorbeeld het primair onderwijs) of zelfs op één specifieke school.

- Ten slotte zijn er grote verschillen in de mate van detaillering. Voor de onderwijsondersteunende beroepen waarvoor een beroepscompetentieprofiel is vastgesteld is er uitgebreide informatie beschikbaar over de verschillende facetten die binnen de kerntaken van de functie belangrijk zijn. Het gaat dan bijvoorbeeld om het proces, de rol en verantwoordelijkheden, de mate van complexiteit, de betrokkenen, de hulpmiddelen, de kwaliteit van het proces en het resultaat en de keuzes en dilemma's. In andere bronnen wordt er alleen melding gemaakt van activiteiten die binnen de context van een taak bij de functie horen. 


\subsection{Functiekenmerken van onderwijsondersteuners}

Op welke vlakken verschillen de drie soorten onderwijsondersteuners van elkaar en waar is er sprake van overeenkomsten? We hebben gekeken naar de taken in de functie, de mate van zelfstandigheid, de te verrichten activiteiten, de manieren waarop er verantwoording wordt afgelegd over deze taken, de vereiste competenties, de mate waarin de vereiste competenties formeel of informeel zijn aangeleerd en de complexiteit van de functie.

Tussen de pedagogisch/verzorgende en pedagogisch/didactische functies zijn er relatief weinig verschillen in de te verrichten taken. Er zijn echter wel verschillen in de mate waarin bepaalde taken voorkomen tussen deze functies en de technisch instrumentele functies. De meeste door ons onderscheiden taken komen minder vaak voor in het takenpakket van de technische onderwijsondersteuners. Uitzondering hierop vormen twee taken op het vlak van practica en experimenten. Deze taken komen juist vaker voor in het takenpakket van ondersteuners met technisch instrumentele functies. De mate van zelfstandigheid bij het uitvoeren van taken is het grootst voor onderwijsondersteuners met pedagogisch/didactische functies en het laagst voor ondersteuners met pedagogisch/verzorgende functies.

Wanneer er wordt gekeken naar de activiteiten die onderwijsondersteuners in hun werk uitvoeren, dan blijkt allereerst dat, voor de meeste activiteiten, de verschillen tussen de drie soorten functies beperkt zijn. De verschillen tussen de uitgevoerde activiteiten zijn duidelijk groter. Wel is er sprake van een duidelijk verschil tussen ondersteuners met technisch instrumentele functies en ondersteuners met pedagogisch/verzorgende of -/didactische functies. Voor vrijwel alle activiteiten geldt dat ondersteuners in technisch instrumentele functies ze minder frequent uitvoeren dan ondersteuners in andere functies. Ook blijken er drie activiteiten te zijn die over de gehele linie van belang zijn. Het gaat hier om (I) overleg voeren of voorgesprekken houden met leraar of docent, (2) het controleren van en rekening houden met voorschriften, reglementen en regels en (3) leerlingen aanspreken op hun gedrag.

Het blijkt dat onderwijsondersteuners over de meeste activiteiten die ze uitvoeren verantwoording afleggen aan de leraar of docent. De uitzonderingen hierop zijn het volgen van nascholing of teamcursussen en de deelname aan teamvergaderingen. Voor deze activiteiten leggen onderwijsondersteuners vooral verantwoording af aan de directie van de school waar ze werkzaam zijn. Ondersteuners met pedagogisch/verzorgende functies leggen minder vaak verantwoording af over de door hen uitgevoerde activiteiten dan ondersteuners met technisch instrumentele functies. Ondersteuners met pedagogisch/didactische functies nemen op dit punt een middenpositie in, maar ze leggen minder vaak verantwoording af aan de leraar of docent; deze groep legt relatief vaak verantwoording af aan de directie van de school waar ze werkzaam zijn. 
Wanneer er wordt gekeken naar de competenties die voor onderwijsondersteunende functies vereist zijn, dan blijkt dat de verschillen tussen de competenties groter zijn dan de verschillen tussen de drie onderscheiden onderwijsondersteunende functies binnen een bepaalde competentie. Verder komt naar voren dat de competenties die van groot belang zijn voor pedagogisch/verzorgende en pedagogisch/didactische functies voor een belangrijk deel overlappen. Dit maakt het moeilijk om op basis van de vergelijking tussen de vereiste competenties aan te geven wat de essentiële verschillen zijn tussen de drie soorten onderwijsondersteunende functies. Er blijken tussen deze functies overigens wel verschillen te bestaan in de mate waarin de competenties informeel zijn aangeleerd. Ondersteuners met pedagogisch/verzorgende functies hebben hun competenties vaker informeel verworven dan ondersteuners met pedagogisch/ didactische of technisch instrumentele functies.

Uit de analyse van factoren die bijdragen aan de complexiteit van de functie komt naar voren dat een beperkt aantal factoren hieraan in grote mate bijdraagt. Het gaat hier om (I) het didactisch correct handelen in verschillende situaties, (2) het werken binnen bestaande kaders, (3) het moeten kunnen omgaan met onverwachte situaties, (4) het moeten kunnen improviseren en (5) het onder verantwoordelijkheid van de leraar of docent werken. Het blijkt dat er tussen de verschillende onderwijsondersteunende functies wel enkele verschillen bestaan in de mate waarin deze factoren bijdragen aan de complexiteit van de functie. Er kan echter niet geconcludeerd worden dat de analyse van de complexiteit van de functies wijst op grote verschillen tussen de drie onderscheiden ondersteunende functies.

De analyses van de functiekenmerken van onderwijsondersteuners hebben laten zien dat er geen sprake is van grote verschillen in de functiekenmerken van pedagogisch/ verzorgende en pedagogisch/didactische functies. Er bleken wel enkele verschillen te zijn tussen deze functies en technisch instrumentele functies. Toch zijn de geconstateerde verschillen in taken, zelfstandigheid, activiteiten, verantwoordelijkheid, competenties en complexiteit in het algemeen vrij beperkt. Dit zou erop kunnen wijzen dat er tussen de drie verschillende soorten onderwijsondersteunende functies ook veel overeenkomsten zijn. De beperkte verschillen in de functiekenmerken zouden echter ook kunnen betekenen dat er mogelijkheden zijn om de gehanteerde indeling in drie soorten onderwijsondersteunende functies nader uit te werken.

\subsection{De positie van onderwijsondersteuners in het Nederlandse onderwijs}

De positie van onderwijsondersteuners hangt in grote mate samen met de context waarin ze werkzaam zijn. Daarbij zijn zowel de onderwijssector als het soort functie waarin men werkzaam is van belang. Onderwijsondersteuners met pedagogisch/ verzorgende functies werken in verschillende onderwijssectoren, maar komen toch vooral voor in het (speciaal) primair onderwijs. Pedagogisch/didactische functies komen zowel in het primair als voortgezet onderwijs voor, maar spelen de grootste 
rol in de BVE. Onderwijsondersteuners met technisch instrumentele functies werken met name in het voortgezet onderwijs en in mindere mate in het speciaal voortgezet onderwijs en de BVE.

Tussen de verschillende onderwijssectoren bestaan er opmerkelijke verschillen in de positie van onderwijsondersteuners binnen de school waarin ze werkzaam zijn. Binnen het speciaal onderwijs spelen onderwijsondersteuners een meer prominente rol, aangezien het aantal leerlingen per onderwijsondersteuner in deze sector veel kleiner is dan in de andere onderwijssectoren. Ook is de verhouding tussen het totale personeelsbestand van de school en het aantal onderwijsondersteuners in het speciaal onderwijs kleiner dan in het gewone onderwijs.

Op deze punten zijn er ook verschillen tussen de drie onderscheiden onderwijsondersteunende functies. Het blijkt dat zowel het aantal leerlingen als het aantal personeelsleden per onderwijsondersteuner voor ondersteuners met technisch instrumentele functies groter is dan voor de andere onderwijsondersteunende functies. Tussen de onderwijsondersteuners zijn er ook verschillen in de gemiddelde tijd dat ze hun huidige functie al uitoefenen en in de vakken waar ze bij betrokken zijn. Ondersteuners met pedagogisch/verzorgende functies zijn gemiddeld genomen het minst lang werkzaam in hun huidige functie en zijn met name betrokken bij de vakken lezen, rekenen en schrijven. Technisch onderwijsondersteuners zijn daarentegen gemiddeld genomen wat langer werkzaam in hun huidige functie en zijn vooral betrokken bij de exacte vakken. Ook het aantal vakken waarbij onderwijsondersteuners in hun werk betrokken zijn hangt samen met het soort functie. Ondersteuners met een technisch instrumentele functie zijn meestal bij slechts één vak betrokken. De meerderheid van de onderwijsondersteuners met pedagogisch/verzorgende functies is daarentegen bij drie of meer vakken betrokken.

Er bestaat een behoorlijke variatie in de opleidingsachtergrond van de opleidingsondersteuners die momenteel in het Nederlandse onderwijs werkzaam zijn. Ondersteuners met pedagogisch/verzorgende functies hebben meestal een opleiding op MBO-niveau gevolgd, maar bij minder dan één op de drie onderwijsondersteuners gaat het om een opleiding onderwijsassistent of MBO SPW. Van de technisch onderwijsondersteuners heeft slechts IO\% een opleiding TOA gevolgd. Voor opleidingsondersteuners met een pedagogisch/didactische functie is het beeld duidelijk anders: De helft van deze onderwijsondersteuners heeft een $\mathrm{HBO}$-opleiding gevolgd. In het algemeen vinden onderwijsondersteuners dat de functie die ze hebben goed aansluit bij de door hen gevolgde opleiding, maar tussen de verschillende soorten functies zijn er wel enkele verschillen. Zo beoordelen ondersteuners met een pedagogisch/didactische functie de aansluiting tussen hun functie en opleiding wat minder positief dan ondersteuners met andere functies.

Over de benutting van hun capaciteiten zijn de meeste onderwijsondersteuners behoorlijk positief. Slechts een kleine minderheid vindt dat hun capaciteiten onvol- 
doende worden benut. Onderwijsondersteuners vinden verder dat ze geen ernstige kennistekorten hebben. Circa de helft van de ondersteuners met technisch instrumentele functies vindt echter wel dat ze enige kennis missen. Ten slotte blijkt dat een meerderheid van de onderwijsondersteuners vindt dat hun kennis en vaardigheden ook bruikbaar zijn in een onderwijsondersteunende functie buiten de school waar ze nu werkzaam zijn.

\subsection{Vier verschillende onderwijsondersteunenende functies}

Hoewel er in het algemeen sprake is van een sterke samenhang tussen de taken van onderwijsondersteuners en de activiteiten die ze uitvoeren, blijkt dat niet alle taken van onderwijsondersteuners geassocieerd kunnen worden met één of meerdere concrete activiteiten. Dit geldt met name voor het organiseren van extra-curriculaire activiteiten, het begeleiden van individuele leerlingen buiten het onderwijsproces, het faciliteren van practica en experimenten, het begeleiden van leerlingen tijdens practica en experimenten, leerlingen bij het inoefenen van beroepsvaardigheden begeleiden en het begeleiden van kleine groepen leerlingen buiten het onderwijsproces. Deze taken zijn wellicht minder direct verbonden met concrete activiteiten in het werk van onderwijsondersteuners.

Een correlatie-analyse tussen taken en activiteiten laat ook zien dat er activiteiten zijn die samenhangen met verschillende taken in onderwijsondersteunende functies. Activiteiten die voor minstens drie taken van belang zijn, zijn: het voorbereiden van onderwijs(deel)taken, het beheren en klaarmaken van lesmateriaal, het geven van verlengde instructie aan leerlingen, de werkwijze en het gedrag van leerlingen observeren, en het rapporteren van observaties en bevindingen aan de leraar of docent.

Een aantal competenties is belangrijk voor verschillende taken en activiteiten. Het gaat om de volgende competenties:

- Het vermogen om verschillende didactische werkvormen toe te passen.

- Het vermogen om ontwikkelingsmogelijkheden van kinderen optimaal te benutten.

- Het vermogen om leerlingen de verzorging te geven die ze nodig hebben.

- Het vermogen om leerlingen op verschillende manieren te beoordelen.

- Het vermogen om de behoefte van leerlingen te interpreteren.

- Het vermogen om de eigen pedagogische opvattingen te integreren in het onderwijsleerproces.

- De kennis van de eindtermen van de eigen onderwijsinstelling.

Om meer inzicht te krijgen in de inhoud van onderwijsondersteunende functies is er ook een principale componenten analyse uitgevoerd op basis van de taken die onderwijsondersteuners uitvoeren. Uit deze analyse kwam naar voren dat, wanneer 
we uitgaan van de taken van onderwijsondersteuners, er sprake is van vier clusters, die duiden het bestaan van vier verschillende onderwijsondersteunende functies. Het gaat achtereenvolgens om:

- Brede niet-technisch onderwijsondersteunende functies: Het gaat hier om functies met 12 relevante en twee niet-relevante taken. De niet-relevante taken zijn practica en experimenten faciliteren en leerlingen tijdens practica en experimenten begeleiden. De functie omvat dus alle taken, behalve de taken die vaak geassocieerd worden met technisch onderwijsondersteuners.

- Technisch onderwijsondersteunende functies: Deze functies omvatten negen relevante en vijf niet-relevante taken. De functies omvatten de voorbereiding en de uitvoering van lessen, het organiseren van extra-curriculaire activiteiten, het begeleiden van groepen leerlingen tijdens het onderwijsproces, het toetsen en beoordelen van leerlingen, practica en experimenten faciliteren, leerlingen tijdens practica en experimenten begeleiden, het begeleiden van leerlingen bij het inoefenen van beroepsvaardigheden en het uitvoeren van administratieve werkzaamheden. Het gaat hier om een onderwijsondersteunende functie waarin practica en experimenten en het inoefenen van beroepsvaardigheden een rol spelen. De functies omvatten ook pedagogisch/didactische activiteiten zoals het uitvoeren van lessen en het beoordelen van leerlingen.

- Technisch begeleiders: In deze functies zijn zes taken van belang. Het begeleiden van en zorg bieden aan leerlingen speelt een belangrijke rol, maar er is geen sprake van het uitvoeren van lessen, het beoordelen en toetsen van leerlingen en het uitvoeren van administratieve werkzaamheden. Practica en experimenten spelen daarentegen wel een rol in deze functies. Het gaat hier dus om onderwijsondersteunende functies waarin het begeleiden van leerlingen centraal staat, maar waar er ook sprake is van practica en experimenten.

- Assistenten: In deze functies zijn zes taken van belang. Het gaat hier om bijdragen aan een goed pedagogisch klimaat, extra-curriculaire activiteiten organiseren, leerlingen beoordelen en toetsen, leerlingen bij het inoefenen van beroepsvaardigheden begeleiden, administratieve werkzaamheden uitvoeren en zorg (fysiek of sociaal-emotioneel) bieden aan leerlingen. Opvallend in deze functies is dat alle taken die gericht zijn op het begeleiden van individuele leerlingen of groepen leerlingen of lessen uitvoeren of voorbereiden niet relevant zijn. Dit betekent dat deze onderwijsondersteunende functies wat verder afstaan van het onderwijsleerproces dan de andere functies.

\subsection{Conclusies}

De analyses in dit rapport hebben duidelijk gemaakt dat de indeling van onderwijsondersteunende functies in een pedagogisch/verzorgend, technisch instrumenteel en een pedagogisch/didactisch profiel slechts ten dele valide is. Uit meerdere analyses waarin de functie-inhoud van onderwijsondersteuners aan de orde kwam bleek dat er 
sprake is van een duidelijke tweedeling tussen enerzijds pedagogisch/verzorgende en pedagogisch/didactische functies en anderzijds technisch instrumentele functies. Dit wordt ondersteund door de analyse in hoofdstuk 5, waarin bleek dat het bij één van de vier functieclusters gaat om brede niet-technische onderwijsondersteunende functies, waarin zowel pedagogische, didactische als verzorgende elementen een rol spelen.

De moeilijkheid om aan te geven op welke vlakken pedagogisch/verzorgende en pedagogisch/didactische onderwijsondersteunende functies van elkaar verschillen komt ook naar voren uit het feit dat de voor deze functies benodigde competenties voor een groot deel overlappen. Er is overigens wel een verschil in de mate waarin ondersteuners met deze functies hun competenties informeel leren. Ondersteuners met pedagogisch/didactische functies blijken meer informeel te leren dan degenen met een pedagogisch/verzorgende functie. Het duidelijke verschil tussen technisch instrumentele functies en pedagogisch onderwijsondersteunende functies komt ook naar voren in de mate waarin er verantwoording wordt afgelegd voor de uitgevoerde activiteiten: ondersteuners met technisch instrumentele functies leggen vaker verantwoording af dan ondersteuners met pedagogisch/verzorgende of pedagogisch/didactische functies. Het blijkt ook dat technisch instrumentele functies minder breed zijn dan pedagogisch/verzorgende en pedagogisch/didactische functies, aangezien technisch onderwijsondersteuners voor het overgrote deel slechts bij het onderwijs in een enkel vak betrokken zijn, terwijl onderwijsondersteuners met andere functies vaak assisteren bij meerdere vakken.

Een tweede belangrijke conclusie is dat er ook veel overeenkomsten zijn tussen de drie soorten onderwijsondersteunende functies. Er blijken meerdere activiteiten te zijn die voorkomen in het werk van alle soorten onderwijsondersteuners. Ook blijkt dat onderwijsondersteuners in alle functies over een aantal belangrijke competenties moeten beschikken, die van belang zijn bij het uitvoeren van een groot aantal activiteiten en taken.

Wanneer er gekeken wordt naar verschillen tussen de onderwijssectoren dan blijkt dat inhoud van het werk van onderwijsondersteuners mede bepaald wordt door de context waarin ze werkzaam zijn. De sector waarin een onderwijsondersteuner werkzaam is bepaalt mede welke taken er in het takenpakket zitten, welke activiteiten worden uitgevoerd en wat de vereiste competenties zijn. Ook hier is er sprake van een tweedeling: enerzijds de ondersteuners in het voortgezet onderwijs en de BVE en anderzijds de ondersteuners in het primair onderwijs en het speciaal primair en voortgezet onderwijs. Met name in het speciaal onderwijs ligt de nadruk op activiteiten die pedagogisch en verzorgend van aard zijn, terwijl het accent in het voortgezet onderwijs en in de BVE ligt op activiteiten waarin de overdracht van vaktechnische kennis en vaardigheden centraal staat. Dit vertaalt zich vanzelfsprekend ook in de competenties die in het werk vereist zijn. 
Ook de positie van onderwijsondersteuners hangt in grote mate samen met de onderwijssector waarin ze werkzaam zijn. Zo nemen onderwijsondersteuners in het speciaal onderwijs een meer prominente positie in, doordat ze een groter gedeelte uitmaken van het totale personeelsbestand op hun school en doordat de verhouding onderwijsondersteuner-aantal leerlingen in deze scholen veel lager is dan in de overige onderwijssectoren.

Een andere opmerkelijke uitkomst van het onderzoek is dat er sprake is van een grote diversiteit in de opleidingsachtergrond van onderwijsondersteuners. Onderwijsondersteuners zijn voor het grootste gedeelte opgeleid op MBO-niveau, maar dit geldt niet voor de onderwijsondersteuners in pedagogisch/didactische functies, die juist vaak een opleiding op HBO-niveau hebben afgerond. In dit licht is het opmerkelijk dat juist onderwijsondersteuners met deze functies vaak vinden dat het werk niet goed aansluit bij de door hen gevolgde opleiding. Kennistekorten treden relatief vaak op bij ondersteuners met technisch instrumentele functies, waarschijnlijk doordat hun kennis en vaardigheden sneller verouderen dan de pedagogische en didactische kennis van ondersteuners met andere functies.

Uit de clusteranalyse van hoofdstuk 5 komt duidelijk naar voren dat er sprake is van 4 soorten onderwijsondersteunende functies:

- Brede niet-technisch onderwijsondersteunende functies.

- Technisch onderwijsondersteunende functies.

- Technisch begeleiders.

- Assistenten.

Dit betekent dat de eerder gehanteerde driedeling in pedagogisch/verzorgend, technisch instrumenteel en pedagogisch/didactisch slechts ten dele valide is. Toch ondersteunt deze uitkomst de analyses in de eerdere hoofdstukken. Allereerst komt de technisch onderwijsondersteuner duidelijk als apart profiel naar voren. Daarnaast lijkt er een tweede technische onderwijsondersteunende functie (technisch begeleiders) te bestaan, met een minder brede functie-inhoud. In plaats van het onderscheid tussen pedagogisch/verzorgende functies en pedagogisch/didactische functies onderscheidt de clusteranalyse enerzijds brede onderwijsondersteunende functies en anderzijds assistenten. In de brede onderwijsondersteunende functies zijn zowel pedagogische, didactische en verzorgende functiekenmerken terug te vinden. Welke elementen het belangrijkst zijn hangt waarschijnlijk in grote mate samen met de onderwijssector waarin de ondersteuner werkzaam is. De assistentfuncties zijn eveneens grotendeels niet-technisch van aard. De onderwijsondersteuners in deze functies hebben echter een veel kleiner takenpakket dan hun collega's met brede onderwijsondersteunende functies.

Vanwege de geconstateerde overlap in de activiteiten die onderwijsondersteuners uitvoeren en de competenties die in het werk vereist zijn kan gesteld worden dat 
de verschillende onderwijsondersteunende functies differentiaties zijn van één onderwijsondersteunend beroep, maar dat er wel sprake is van een viertal differentiaties. Deze differentiaties zijn gebaseerd op de soorten taken die onderwijsondersteuners uitvoeren. Twee functiekenmerken blijken daarbij van cruciaal belang: technisch instrumentele werkzaamheden (het al dan niet betrokken zijn bij practica en experimenten) en de breedte van het takenpakket. 


\section{Geraadpleegde Literatuur}

Vrieze, G., Houben, L., \& Kessel, N. van (2003). Functiedifferentiatie in het onderwijs. Den Haag: Ministerie van OCW.

Onderwijsraad (2003). Een kwalificatiestructuur voor het onderwijs. Den Haag: Onderwijsraad.

Ministerie van OCenW (2003). Een samenhangend opleidingenstelsel voor de onderwijsberoepen. Den Haag: Ministerie van OCenW.

\section{Beroepscompetentieprofielen en functie-omschrijvingen}

Beroepscompetentieprofiel Onderwijsassistent PO/SO. OVDB, Bunnik, 2004.

Beroepscompetentieprofiel Onderwijsassistent VO/Bve. OVDB, Bunnik, 2005.

Beroepscompetentieprofiel Technisch Onderwijsassistent. Vapro, Leidschendam, 2004 .

Functiebeschrijvingen voor Onderwijsassistent BO, Klassenassistent (V)SO, Lerarenondersteuner BO, Lerarenondersteuner SBO/WECSBO/WEC. Functiebeschrijvingen door Ministerie van OCW op: http://www.minocw.nl/ondersteunendp/functiebeschrijvingen.html.

Functiebeschrijvingen voor Instructeur BVE en Tutor BVE. Functiebeschrijvingen door Koning Willem I College op: http://www.kwic/personeel/profielen. 


\section{Bijlage: Verslag online enquête Onderwijsondersteuners}

\section{Opzet van de enquête}

De enquête over onderwijsondersteuners in het Nederlandse onderwijs is in opdracht van het LPBO door het Researchcentrum voor Onderwijs en Arbeidsmarkt (ROA) van de Universiteit Maastricht uitgevoerd. De vragenlijst was gericht op drie groepen: Directeuren of schoolleiders, leraren en docenten en de onderwijsondersteuners zelf. De vragenlijst bevatte een groot aantal vragen over de inhoud van de onderwijsondersteunende functies. Het ging hierbij om taken, activiteiten, vereiste competenties, zelfstandigheid, verantwoordelijkheid en complexiteit van het werk. De vragen zijn opgesteld door het ROA en besproken met een begeleidingscommissie, die werd aangestuurd door het LPBO.

De enquête is geprogrammeerd in het online software pakket Netquestionnaires. Het ging om één enkele vragenlijst die op basis van een selectievraag over de functie van de respondent een bepaalde routing volgde. De vragen die gesteld werden waren dus afgestemd op de drie groepen respondenten (directeuren, leraren en onderwijsondersteuners). Daarbij werd er overigens op gelet dat ook de vragen op elkaar afgestemd werden. Zo werden aan de drie groepen vergelijkbare vragen voorgelegd over de functie-inhoud van onderwijsondersteuners.

\section{Start en verloop van de enquête}

De enquête is gestart op I2 december 2006. Op die datum is een uitnodiging gestuurd aan de directeuren van circa 3.000 scholen in Nederland. Het ging hierbij om scholen uit het primair onderwijs (PO), speciaal primair onderwijs (SPO), voortgezet onderwijs (VO), speciaal voortgezet onderwijs (SVO) en beroeps- en volwasseneneducatie (BVE). In de loop van december is aan de scholen waarvan er nog geen reactie ontvangen was een reminder verstuurd. In de tweede week van januari 2007 is er een tweede reminder verzonden. De vragenlijst heeft uiteindelijk tot en met 16 januari 2007 opengestaan. 


\section{Overzicht van de behaalde respons}

Op 17 januari was de bruto respons 902. Met bruto respons wordt bedoeld die respondenten die de link naar de vragenlijst hebben aangeklikt. Aangezien een aantal respondenten niet verder is gegaan met de vragenlijst is de netto respons lager: 655 cases. Bij analyse van de antwoorden bleek dat, ondanks de meerdere aanwijzingen (in de uitnodigingsmail, in de online vragenlijst), dat een aantal respondenten de vragenlijst invulde voor ondersteunende functies die niet direct bij het onderwijs betrokken zijn (conciërges, administratief personeel, etc). Het ging in totaal om 4I cases. Nadere analyse laat ook zien dat voor een aantal cases alleen de persoonlijke gegevens van de respondent zijn ingevuld, en antwoorden voor de verdere vragen missen. Het gaat hier om circa I4O cases. Dit betekent dat de uiteindelijke respons 472 cases is.

In het onderstaande overzicht wordt een gedetailleerd overzicht gegeven van de behaalde respons naar:

I. Respondent (schoolleider, leraar, onderwijsondersteuner (OWO))

2. Soort onderwijsondersteunende functie (Pedagogisch/verzorgend, Technisch instrumenteel, Pedagogisch/didactisch of anders)

3. Soort school

\section{Primair Onderwijs}

$\begin{array}{lcccc}\text { Functie } & \text { Directeur } & \text { Leraar } & \text { OW0 } & \text { Totaal } \\ \text { Pedagogisch/verzorgend } & 49 & 14 & 23 & 86 \\ \text { Technisch instrumenteel } & 1 & 0 & 0 & 1 \\ \text { Pedagogisch/didactisch } & 5 & 4 & 3 & 12 \\ \text { Anders } & 1 & 1 & 3 & 5 \\ \text { Totaal } & 56 & 19 & 29 & 104\end{array}$

Speciaal Primair Onderwijs

$\begin{array}{lcccc}\text { Functie } & \text { Directeur } & \text { Leraar } & \text { OW0 } & \text { Totaal } \\ \text { Pedagogisch/verzorgend } & 7 & 9 & 11 & 27 \\ \text { Technisch instrumenteel } & 0 & 0 & 0 & 0 \\ \text { Pedagogisch/didactisch } & 3 & 1 & 2 & 6 \\ \text { Anders } & 0 & 0 & 0 & 0 \\ \text { Totaal } & 10 & 10 & 13 & 33\end{array}$


Voortgezet Onderwijs

$\begin{array}{lcccc}\text { Functie } & \text { Directeur } & \text { Leraar } & \text { OW0 } & \text { Totaal } \\ \text { Pedagogisch/verzorgend } & 37 & 17 & 28 & 82 \\ \text { Technisch instrumenteel } & 50 & 30 & 41 & 121 \\ \text { Pedagogisch/didactisch } & 8 & 6 & 3 & 17 \\ \text { Anders } & 4 & 0 & 4 & 8 \\ \text { Totaal } & 99 & 53 & 76 & 228\end{array}$

\section{Speciaal Voortgezet Onderwijs}

$\begin{array}{lcccc}\text { Functie } & \text { Directeur } & \text { Leraar } & \text { OW0 } & \text { Totaal } \\ \text { Pedagogisch/verzorgend } & 12 & 3 & 6 & 21 \\ \text { Technisch instrumenteel } & 2 & 0 & 1 & 3 \\ \text { Pedagogisch/didactisch } & 5 & 2 & 4 & 11 \\ \text { Anders } & 0 & 0 & 1 & 1 \\ \text { Totaal } & 19 & 5 & 12 & 36\end{array}$

BVE

$\begin{array}{lcccc}\text { Functie } & \text { Directeur } & \text { Leraar } & \text { OW0 } & \text { Totaal } \\ \text { Pedagogisch/verzorgend } & 4 & 2 & 5 & 11 \\ \text { Technisch instrumenteel } & 2 & 3 & 6 & 11 \\ \text { Pedagogisch/didactisch } & 7 & 6 & 4 & 17 \\ \text { Anders } & 2 & 0 & 0 & 2 \\ \text { Totaal } & 15 & 11 & 15 & 41\end{array}$

Andere school

$\begin{array}{lcccc}\text { Functie } & \text { Directeur } & \text { Leraar } & \text { OWO } & \text { Totaal } \\ \text { Pedagogisch/verzorgend } & 9 & 9 & 3 & 21 \\ \text { Technisch instrumenteel } & 3 & 1 & 0 & 4 \\ \text { Pedagogisch/didactisch } & 2 & 0 & 1 & 3 \\ \text { Anders } & 1 & 0 & 1 & 2 \\ \text { Totaal } & 15 & 10 & 5 & 30\end{array}$

Totaal

$\begin{array}{lcccc}\text { Functie } & \text { Directeur } & \text { Leraar } & \text { OWO } & \text { Totaal } \\ \text { Pedagogisch/verzorgend } & 118 & 54 & 76 & 248 \\ \text { Technisch instrumenteel } & 58 & 34 & 48 & 140 \\ \text { Pedagogisch/didactisch } & 30 & 19 & 17 & 66 \\ \text { Anders } & 8 & 1 & 9 & 18 \\ \text { Totaal } & 214 & 108 & 150 & 472\end{array}$


